\title{
A new ammonoid fauna from the Gattendorfia-Eocanites Genozone of the Anti-Atlas (Early Carboniferous; Morocco)
}

\author{
Jürgen Bockwinkel ${ }^{*, 1}$ \& Volker Ebbighausen**,2 \\ ${ }^{1}$ Dechant-Feinstraße 22, D-51375 Leverkusen, Germany \\ 2 Engstenberger Höhe 12, D-51519 Odenthal, Germany
}

Received August 4, 2005, accepted September 19, 2005

Published online zzz

With 40 figures

Key words: ammonoids, biostratigraphy, Early Carboniferous, Anti-Atlas, Morocco.

\begin{abstract}
From the eastern part of the Tafilalt (Anti-Atlas, Morocco), rich assemblages of ammonoids of the Gattendorfia-Eocanites Genozone are described. The detailed investigation of an outcrop near Mfis in the south-eastern Tafilalt yielded a diverse fauna with 24 species, of which 13 are new. The genus Weyerella n. gen. is newly erected with Weyerella protecta $\mathrm{n}$. sp. as type species. Furthermore, the following new species are described: Paragattendorfia aboussalamae n. sp., Acutimitoceras hollardi n. sp., Acutimitoceras posterum n. sp., Acutimitoceras mfisense n. sp., Acutimitoceras occidentale n. sp., Imitoceras oxydentale n. sp., Kazakhstania nitida n. sp., Zadelsdorfia debouaaensis n. sp., Weyerella minor n. sp., Eocanites simplex n. sp., Eocanites rtbeckeri n. sp., and Eocanites dkorni n. sp. The state of preservation of the ammonoids as limonitic steinkern specimens permits a detailed study of sutures and conch ontogeny.
\end{abstract}

Schlüsselwörter: Ammonoidea, Biostratigraphie, Unter-Karbon, Anti-Atlas, Marokko.

\section{Zusammenfassung}

Aus dem östlichen Tafilalt (Anti-Atlas, Marokko) wird eine Ammonoideen-reiche Abfolge aus der Gattendorfia-Eocanites Genus-Zone beschrieben. Ein im Detail untersuchtes Profil bei Mfis hat eine individuenreiche und diverse pelagische Fauna mit 24 Arten geliefert, von denen 13 neu sind. Die Gattung Weyerella n. gen. wird mit Weyerella protecta n. sp. als Typusart aufgestellt. Weitere neue Arten sind: Paragattendorfia aboussalamae n. sp., Acutimitoceras hollardi n. sp., Acutimitoceras posterum n. sp., Acutimitoceras mfisense n. sp., Acutimitoceras occidentale n. sp., Imitoceras oxydentale n. sp., Kazakhstania nitida n. sp., Zadelsdorfia debouaaensis n. sp., Weyerella minor n. sp., Eocanites simplex n. sp., Eocanites rtbeckeri n. sp. und Eocanites dkorni n. sp. Die in Limonit erhaltenen Steinkerne erlauben eine Detailuntersuchung der Lobenlinien und der Gehäuse-Ontogenie.

\section{Introduction}

During the transition from the Devonian into the Carboniferous a dramatic turnover of pelagic faunas took place. This faunal break was one of the most dramatic in the history of the Ammonoidea. The investigation of ammonoid assemblages after this crisis offers an opportunity to study the faunal recovery after the extinction event. To understand the way of evolutionary change, it is relevant to study the reestablishment of diversity and to describe the morphological disparity of the winners of the crisis.

\footnotetext{
* Corresponding author: e-mail: JBockwinkel@t-online.de

***E-mail: Volker@vxr.de 
There are few areas in the world where detailed and uninterrupted ammonoid successions have been investigated so far. Rich assemblages from the Early Tournaisian, the Gattendorfia-Eocanites Genozone, are rather rare and particularly known from the Rhenish Mountains (Vöhringer 1960; Korn 1994), Thuringia (Weyer 1977; Bartzsch \& Weyer 1982), Silesia (Weyer 1965), and Guizhou (Ruan 1981). With the discovery of an ammonoid-rich succession of early Carboniferous claystones in the eastern Anti-Atlas of Morocco, we were able to contribute to the knowledge of this evolutionary phase of the Ammonoidea.

The object of the present study is the documentation of the newly discovered ammonoid fauna and a comparison with other time-equivalent assemblages. The succession was investigated and measured in detail, and the fauna was collected bed by bed. The faunal spectrum is comparatively diverse and proved as the richest ammonoid fauna of the Gattendorfia-Eocanites Genozone in North Africa so far.

\section{Historical Review}

It was probably Meyendorff (1939) who reported earliest Carboniferous strata with ammonoid faunas for the first time from North Africa. These came from Timimoun (region Gourara, Algeria), and the species Gattendorfia cf. crassa Schmidt, 1924 and Gattendorfia sp. were mentioned.

In the excursion guide of the International Geological Congress of Algiers, Clariond \& Hindermeyer (in Choubert et al. 1952) described a Famennian to Viséan succession at Aguelmous near Fezzou (Ma'der, Morocco) with "Muensteroceras sp." and "Aganides sp.". Later, Hollard (1956) noticed finds of Gattendorfia from Jebel Tazout in the middle Dra Valley; furthermore, he reported an occurrence of Gattendorfia from the region of Fezzou, discovered by P. Jacquemont. Hollard (1958) described the section at Aguelmous in more detail. The fossil horizons with "Gattendorfia sp." and "Imitoceras guerichi Schindewolf, 1923" were attributed to the early Tournaisian. In a later publication, Hollard (1970) discussed these in a palaeogeographic context. Using a lithological comparison, Hollard (1958) proposed an early Tournaisian age for sediments in the vicinity of Taouz near the mine of Mfis, but could not provide evidence such as characteristic fossils. Two years later, Hollard (1960) reported finds of "Protocanites", "Imito- ceras subbilobatum (Münster)", "Pericyclus gr. princeps (De Koninck)" and a fragment of Gattendorfia. The fauna was surface collected north of Taouz and hence, no detailed stratigraphic assignment was possible.

Conrad et al. (1970) reported Gattendorfia from the Saoura Valley near Béni-Abbès in Algeria. In her dissertation, Conrad (1984) investigated the stratigraphy, sedimentology and structural evolution of the Carboniferous sedimentary rocks of the Central Sahara. She listed a number of Tournaisian ammonoids from Algerian localities, among these a fauna with Gattendorfia from Timimoun.

Intensive field work and rich new collections yielded new data on Tournaisian ammonoids of North Africa. These faunas come from (1) the Amessoui Syncline at El Atrous (Tafilalt, AntiAtlas, Morocco) where a Middle Tournaisian fauna with Goniocyclus and Protocanites was found (Korn et al. 2002), (2) from Bouhamed, also in the Amessoui Syncline, where a rather diverse early Late Tournaisian assemblage with Pericyclus, Progoniatites and others was collected (Korn et al. 2003), and (3) from Meyendorff's locality near the Gara el Kahla (Timimoun, Algeria), from which the fauna with Gattendorfia and Acutimitoceras originated (Ebbighausen et al. 2004).

\section{The ammonoid-bearing section near Mfis}

In the central Tafilalt of the Anti-Atlas (Morocco), cephalopod limestones are the predominant late Famennian lithology. This sedimentary unit was interpreted as Tafilalt Platform (Wendt et al. 1984; Wendt 1988). Characteristic sections were described from the Bordj d'Erfoud (Korn 1999) and Bou Tchrafine (Becker \& House 2000). A general view of the Famennian amonoid zones of the eastern Anti-Atlas is documented by Becker et al. (2002). Sections in the south-eastern Tafilalt show a late Famennian transition from cephalopod limestones into claystone and sandstone successions of more than one hundred metres thickness. Sedimentary rocks that contain Carboniferous ammonoids are only known from the upper part of this partly siliciclastic rock unit.

In connection with the doctorate thesis of Kaiser (2005), a well-exposed succession of Early Carboniferous (Tournaisian) claystones was discovered in the south-eastern Tafilalt near Mfis, $18 \mathrm{~km}$ north-east of Taouz (Fig. 1). The section 


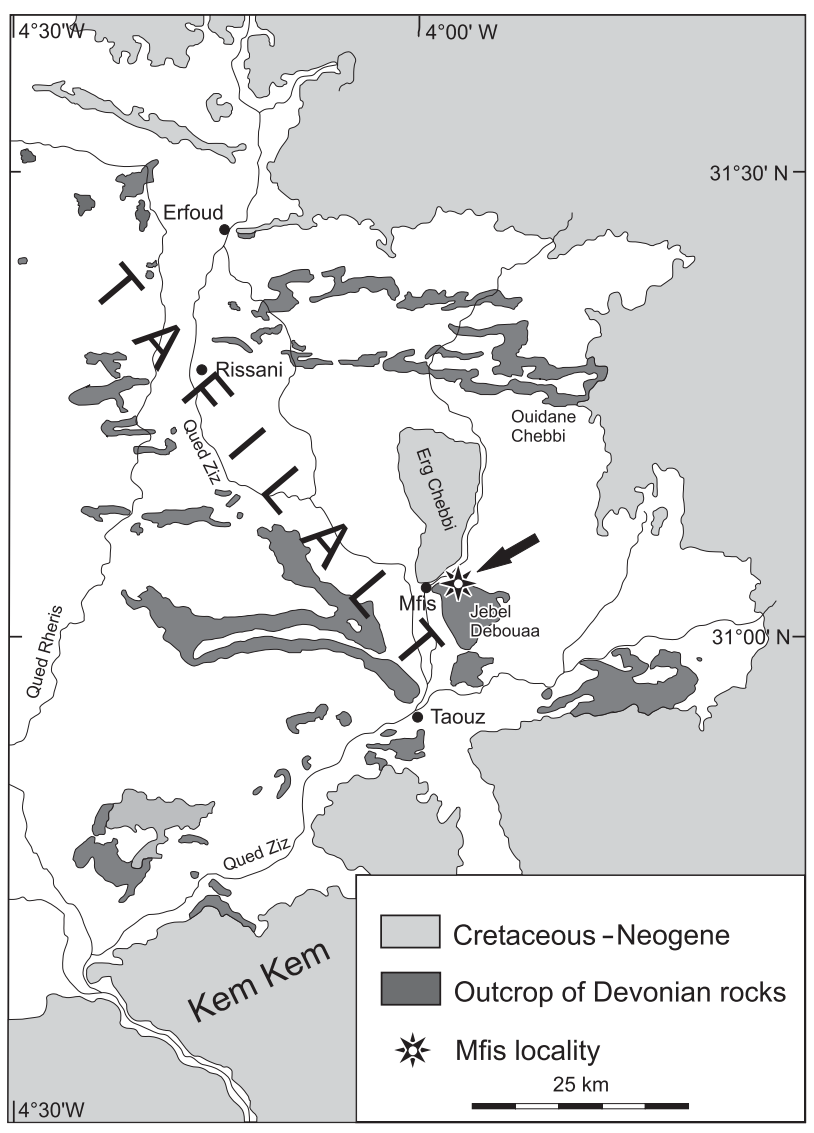

Fig. 1. Geological map of the Tafilalt (Anti-Atlas, Morocco) with the position $\left(\mathrm{N} 31^{\circ} 02^{\prime} 780^{\prime \prime} \mathrm{W} 03^{\circ} 55^{\prime} 739^{\prime \prime}\right)$ of the ammonoid locality $2.5 \mathrm{~km}$ east of Mfis, redrawn from Korn et al. (2002).

contains rich ammonoid assemblages in four horizons and delivered nearly 1000 well-preserved ammonoid specimens. The investigated section (Fig. 2) has a total thickness of $252 \mathrm{~m}$, of which $31 \mathrm{~m}$ have been sampled in detail. The following stratigraphic succession has been documented, together with the succession of fossils.

Bed A. Approximately $1 \mathrm{~m}$ greenish-grey to white claystone, deeply weathered, without macrofossils. This bed is interpreted as Hangenberg Black Shale equivalent, according to the lithology and a RFA analysis (Knut Hahne, GeoForschungsZentrum Potsdam)

Bed B. Approximately $220 \mathrm{~m}$ fine-grained sandstones. The lower part of the succession is thin-bedded; in the middle part, some compact beds are up to one metre thick. The upper part shows a gradual increase of shaly interbeds. Sideritic nodules occur near the top. Macrofauna is missing in this rock unit.

Bed 1a. $1.00 \mathrm{~m}$; weathered, greyish-green fine-grained platy sandstone with mica flakes. Nodular and irregular, reddish-brown structures are distributed on the upper surfaces or within the bed. No macrofossils.

Bed 1b. $2.60 \mathrm{~m}$; deeply weathered, in fresh condition bluishgrey claystone.

Bed 1c. $9.10 \mathrm{~m}$; greyish-green silty shales with dark red sideritic nodules, particularily common in the upper part. The upper third of the unit contains a well-preserved fauna. ammonoid fauna (Fig. 3) orthocone cephalopods, indet. rugose coral, indet., aff. Patularima (1 specimen)
Bed 1d. $35 \mathrm{~cm}$; grey, fine-grained sandstone, platy in the lower part and compact in the upper part; unfossiliferous.

Bed 2. Up to $15 \mathrm{~cm}$; dark red, weathered to black, haematitic crust of a fine-grained sandstone, densely connected with the upper surface of bed $1 \mathrm{~d}$, sometimes interfingering. Ammonoid fauna with large specimens up to $100 \mathrm{~mm}$ conch diameter.

ammonoid fauna (Fig. 3)

orthocone cephalopods, indet.

rugose coral, aff. Ufimia sp. indet. (2 specimens); solitary coral indet. (1 specimen)

Bed 3. $3.10 \mathrm{~m}$; greenish-grey claystone, unfossiliferous.

Bed 4. $8 \mathrm{~cm}$; yellowish fine-grained sandstone, lower surface covered with tool marks of $2-3 \mathrm{~cm}$ width.

Bed $5.40 \mathrm{~cm}$; greenish-grey claystone, unfossiliferous.

Bed 6. up to $5 \mathrm{~cm}$; greyish-yellow fine-grained sandstone, wedging out laterally, with some phosphoritic lenses up to $1 \mathrm{~cm}$.

Bed 7. $4.50 \mathrm{~m}$; silty claystone with abundant, lenticular dark red sideritic nodules. The lower part contains a well-preserved ammonoid fauna, all specimens are small and preserved in limonite. ammonoid fauna (Fig. 3)

fragments of orthocone cephalopods, indet.

Ontaria sp. indet., Guerichia venustiformis (Sadykov, 1962), nuculid indet.

pleurotomariid gastropod, Retispira sp., Vorticina $\mathrm{sp}$.

crinoid columnalia

Productina sp. indet., Aulacella? sp. indet.

solitary rugose coral, indet.

ostracods of Thunringian ecotype, Entomozoidae (?), ?Richterina, ?Maternella

trace fossils

Bed 8a. up to $12 \mathrm{~cm}$; slightly carbonatic fine-grained sandstone rich in clay and siderite, with cone-in-cone structures, laterally wedging out.

Bed 8 b. $30 \mathrm{~cm}$; greenish-grey claystone, unfossiliferous.

Bed 8 c. up to $9 \mathrm{~cm}$; slightly carbonatic fine-grained sandstone, partly sideritic with phosphoritic lenses of $1-2 \mathrm{~cm}$. Poor in fossils.

brachiopod fragments

conulariid

Bed 9. $6.00 \mathrm{~m}$; silty shales, greenish-grey with abundant lenticular, dark red sideritic nodules. Two thin siderite beds occur in the lower third of the unit. The upper part contains a diverse, well-preserved fauna that is restricted to a limited horizon.

ammonoid fauna (Fig. 3)

fragments of orthocone cephalopods, indet.

Ontaria sp., Guerichia sp. (common), sp. indet.

Retispira sp., Euphemites sp., Loxonematidae indet., Pleurotomariidae indet., two genera

trilobite fragments

crinoid columnalia

chonetid brachiopod fragments

Ufimia sp., small solitary coral

ostracods of Thuringian ecotype, Entomozoidae trace fossils

Bed 10. $22 \mathrm{~cm}$; compact, hard calcareous sandstone with brown sideritic nodules on the uneven upper surface. The bed forms an elevation that is well visible in the field.

Above this section, the following succession is largely covered by scree. A detailed study was impossible. Two samples were taken (bed 11).

appr. $0.5 \mathrm{~m}$ above bed 10: claystones with

Guerichia sp. (common)

chonetid brachiopods, Orbiculoidea? sp.

ostracods of Thunringian ecotype (abundant), among these Villozona, Rectonariidae, Healdiidae, small Entomozoidae

appr. $3 \mathrm{~m}$ above bed 10: claystones with

Guerichia sp. (common)

chonetid brachiopods 
a ramiform conodont

ostracods of Thunringian ecotype, among these forms of the type Rectonariidae, Amphissitidae, Acratia, Bairdia, Healdiidae (very abundant), Entomozoidae: ?Richterina, ?Maternella (rare)

The section ends with a wide flat surface that is completely covered with scree. Approximately $220 \mathrm{~m}$ north of the section, a poorly preserved middle Tournaisian ammonoid assemblage, containing Zadelsdorfia sp., Protocanites sp., and Imitoceras sp., was found. A similar fauna was described from El Atrous, southern Tafilalt (Korn et al. 2002).

\section{Age of the ammonoid fauna}

The newly discovered ammonoid assemblages do not contain any of the well-known index fossils. Therefore, the discussion of their stratigraphic position has to be based on other taxa and re-

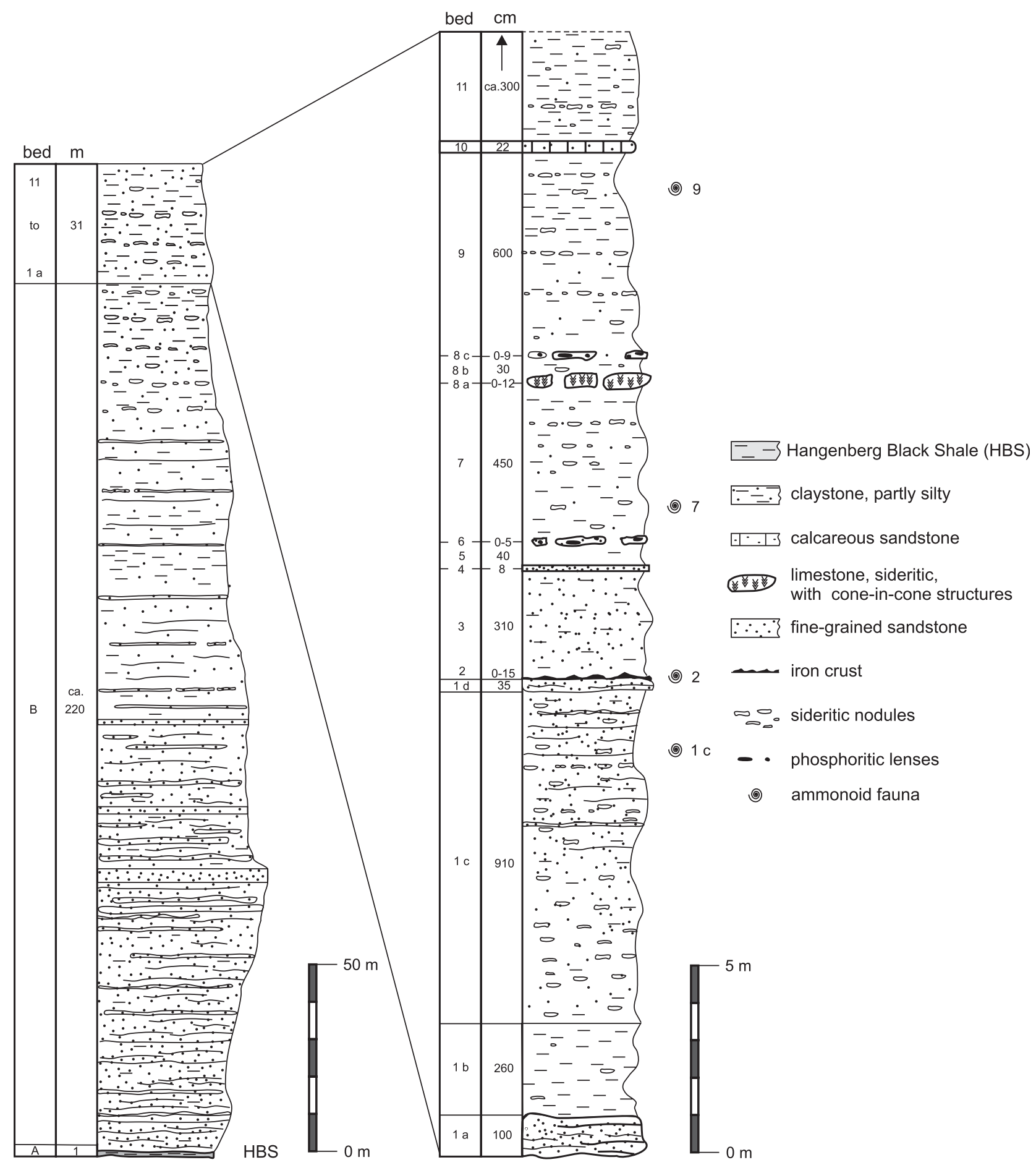

Fig. 2. Lithostratigraphy of the Late Devonian to Early Tournaisian beds near Mfis, Tafilalt, Morocco. 


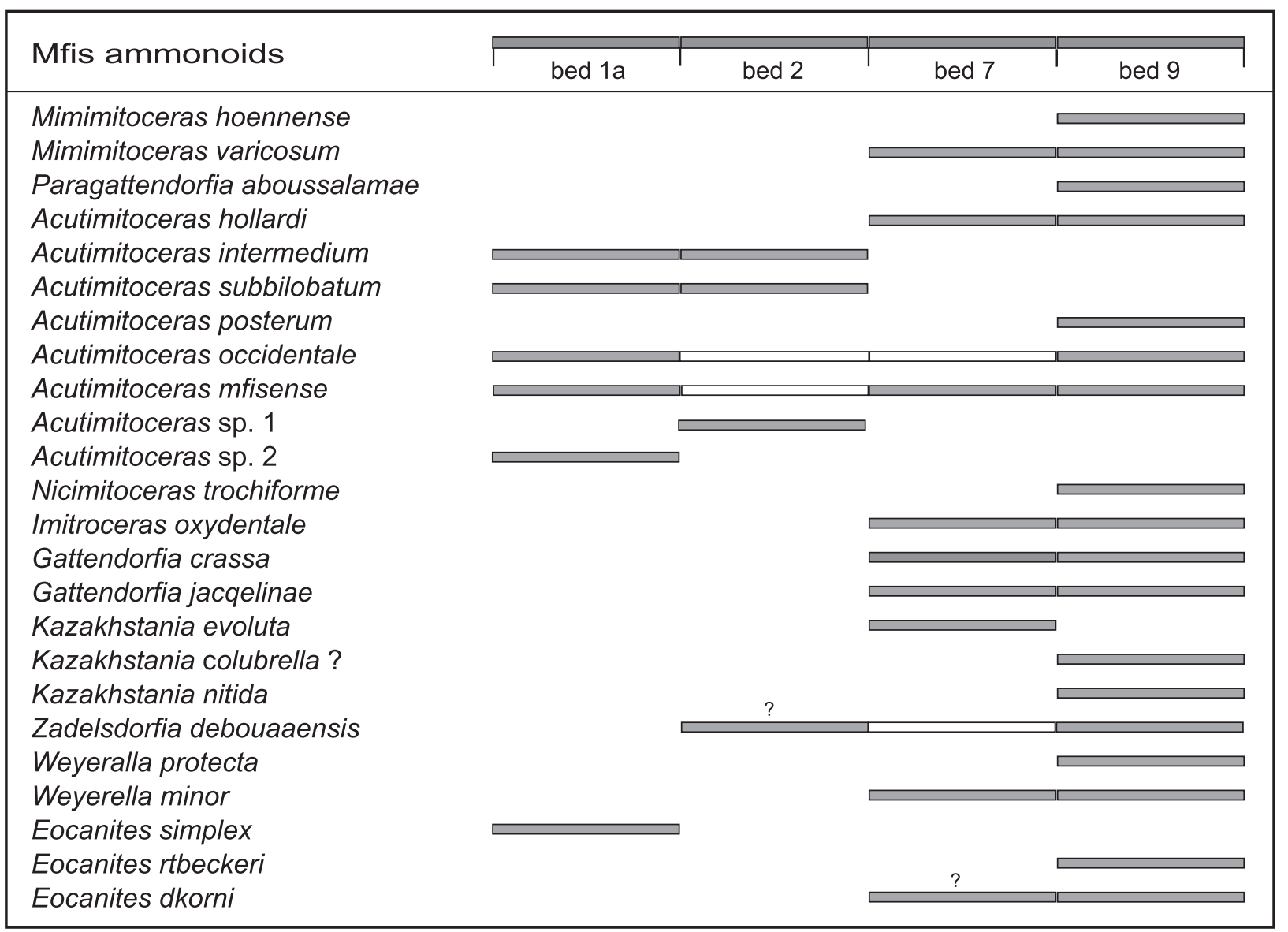

Fig. 3. Distribution of the ammonoid species in the section near Mfis.

mains problematic. The composition of the assemblages with genera such as Acutimitoceras, Gattendorfia, Kazakhstania, Zadelsdorfia and Eocanites proves that they belong to the Early Tournaisian Gattendorfia-Eocanites Genozone.

Probably all four faunal complexes belong to a narrow time interval in the upper part of the Gattendorfia-Eocanites Genozone (Fig. 4). The rich assemblages from bed 7 and bed 9 differ from the lower two less diverse faunas. The occurrence of Kazakhstania evoluta (Vöhringer, 1960) in bed 7, up to now reported only from the Pseudarietites westfalicus Zone and Paragattendorfia patens Zone, indicate a position in the higher part of the Gattendorfia-Eocanites Genozone. Beds 7 and 9 yielded Gattendorfia jacquelinae Ebbighausen et al. 2004; this can be interpreted as belonging to the uppermost Gattendorfia-Eocanites Genozone above the Paragattendorfia patens Zone in a yet unzoned interval, as discussed by Korn \& Weyer (2003).

The lack of Kahlacanites and the presence of Eocanites rtbeckeri n. sp., a possible ancestor of Kahlacanites in bed 9, may indicate a stratigraphic position slightly below the fauna from Timimoun in Algeria (Ebbighausen et al. 2004).
The assemblages from Mfis do not contain any of the ribbed forms, i.e., the genera Paprothites, Pseudarietites and Paralytoceras, which are very common in the occurrences in Germany and China. The same is true for the oxyconic forms of the early Tournaisian, such as Acutimitoceras acutum Schindewolf, 1923, Nicimitoceras acre Vöhringer, 1960, and Voehringerites Manger, 1971. The lack of these taxa may be due to stratigraphy, such as a position above the classical Gattendorfia Stufe.

\section{Palaeontological descriptions}

Abbreviations used in the text are ah - apertural height, dm - conch diameter, uw - umbilical width, wh - whorl height, ww - whorl width, iz - imprint zone, IZR - imprint zone rate, calculated (wh - ah)/wh (see Korn \& Weyer 2003), WER - whorl expansion rate, calculated $[\mathrm{dm} /(\mathrm{dm}-\mathrm{ah})]^{2}$ (Fig. 5A), HBS = Hangenberg Black Shale equivalent. Abbreviations for institute collections are BGRB - Bundesanstalt für Geowissenschaften und Rohtoffe, Außenstelle Berlin, BSP - Bayerische Staatssammlung für Paläontologie und Historische Geologie, München, IGT - Institut für Geowissenschaften, Universität Tübingen, MBG - Geologisch-Paläontologisches Institut, Universität Marburg. Described and illustrated specimens are housed in the cephalopod collection of the Museum für Naturkunde der Humboldt-Universität zu 


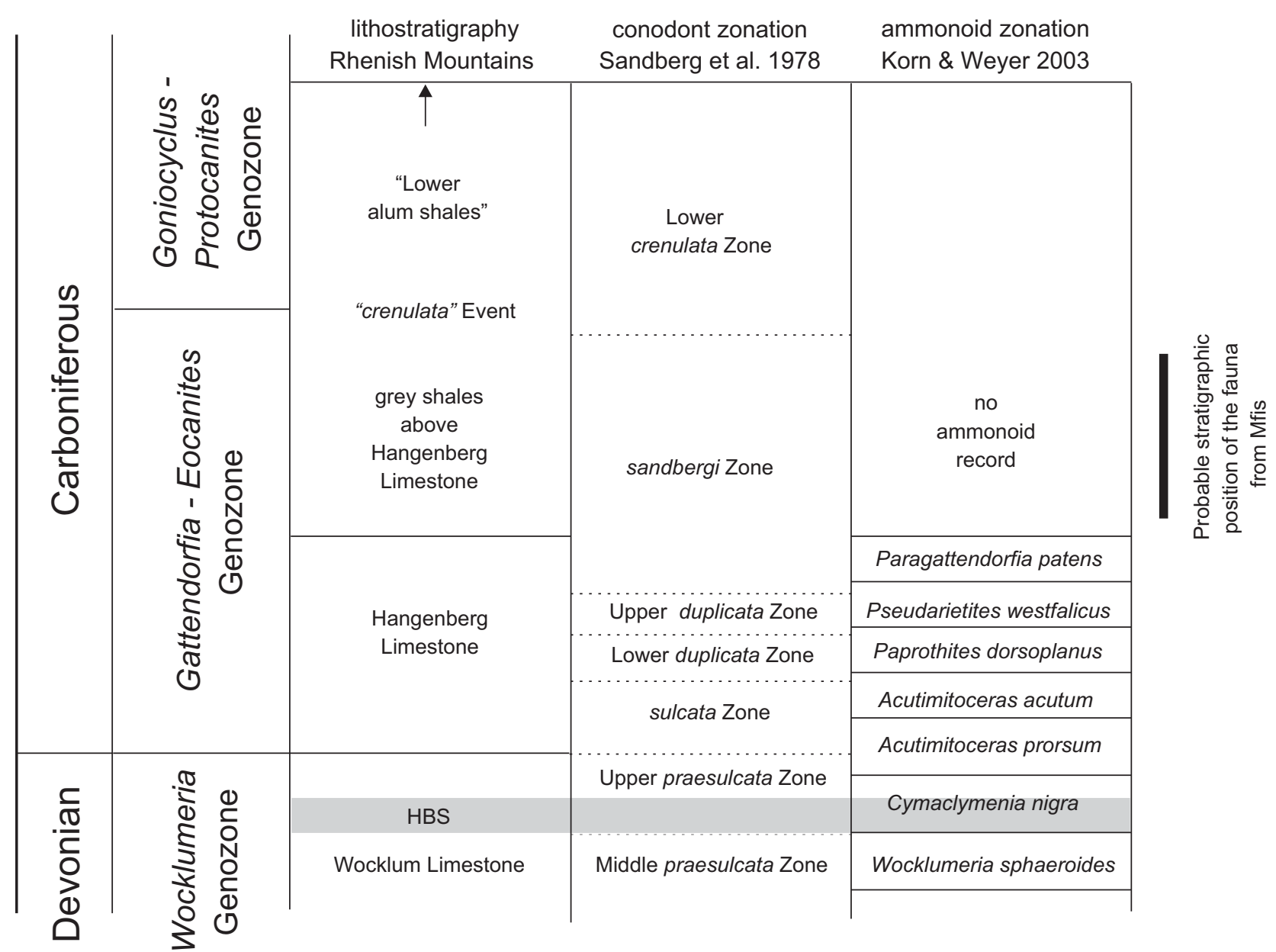

Fig. 4. Chronostratigraphy, ammonoid and conodont zonations in the northern Rhenish Mountains, after Korn \& Weyer, (2003). [HBS = Hangenberg Black Shale equivalent]

Berlin, with the catalogue numbers MB.C.3807.1 MB.C.3841.2. The terminology of the suture line (Fig. 5B) follows Korn et al. (2003). Synonymy lists were obtained from the database GONIAT, version 3.00 (Kullmann \& Korn 2001).

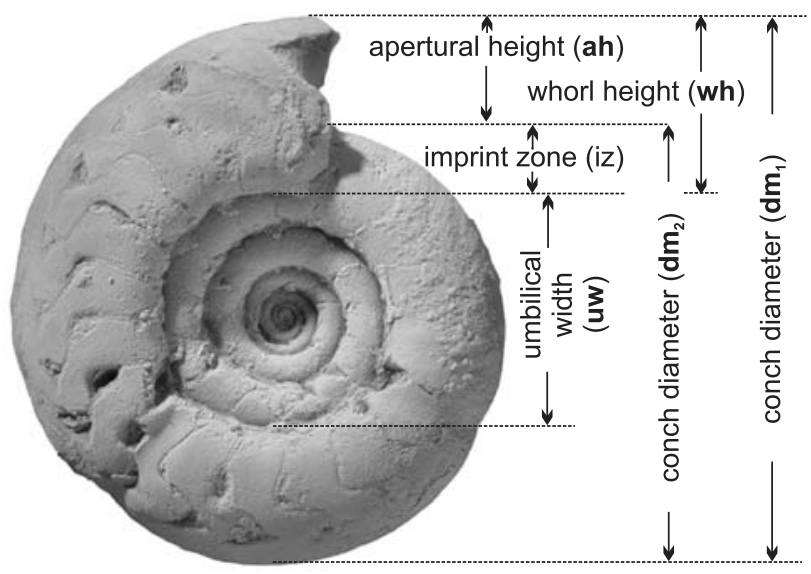

Order Goniatitida Hyatt, 1884

Superfamily Prionoceratoidea Hyatt, 1884

Family Prionoceratidae Hyatt, 1884

Subfamily Prionoceratinae Hyatt, 1884
A $\quad$ WER $=\left(\frac{\mathrm{dm}_{1}}{\mathrm{dm}_{2}}\right)^{2}$
$\mathrm{IZR}=(\mathrm{wh}-\mathrm{ah}) / \mathrm{wh}$

Fig. 5. A - Conch parameters, calculated ratios and rates. B - Suture nomenclature of the investigated ammonoids, after Korn \& Klug (2002). E, external lobe; A, adventive lobe; L, lateral lobe; U, umbilical lobe; I, internal lobe. 

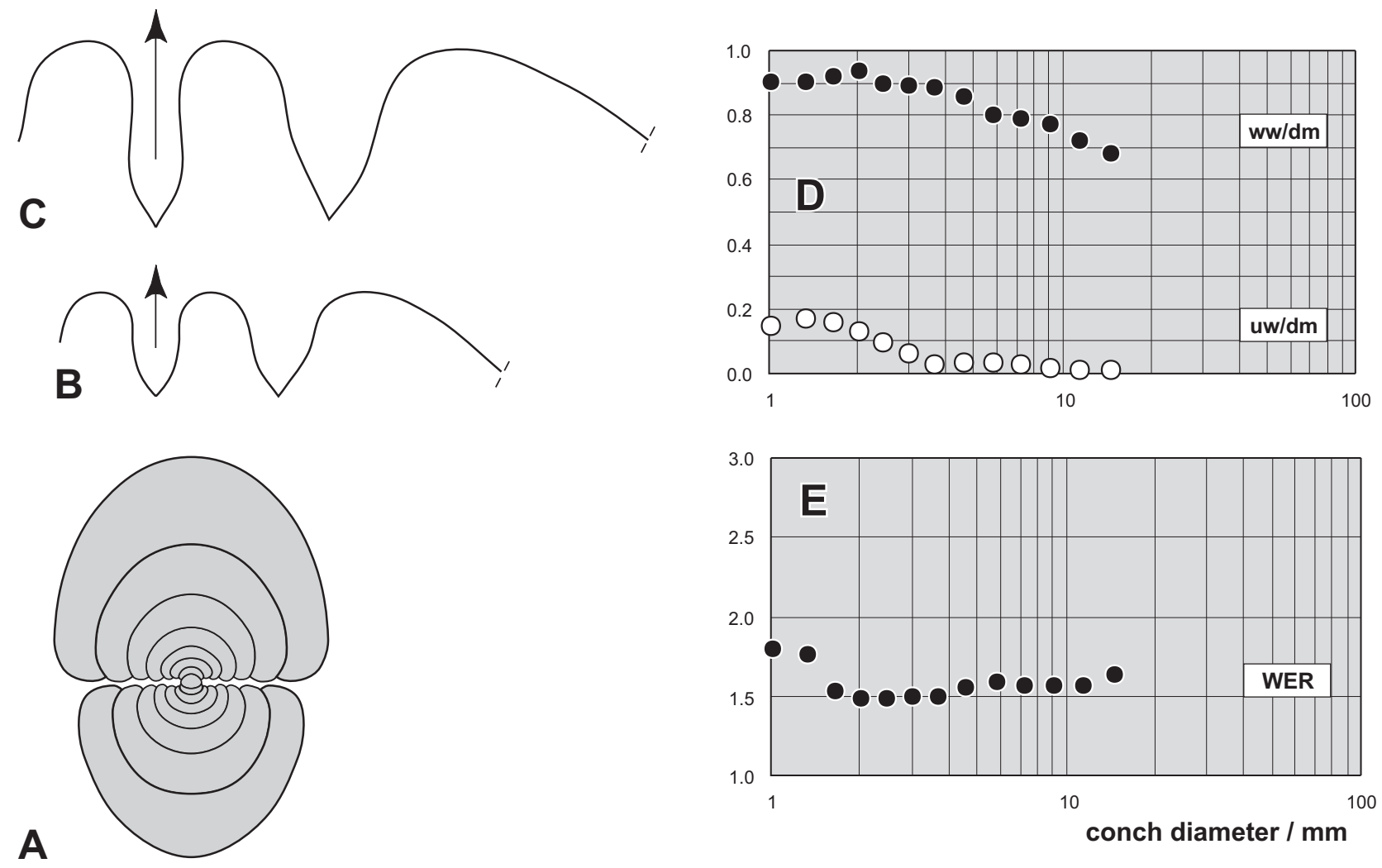

Fig. 6. Cross section (A), suture lines (B, C) and bivariate plots (D, E) of Mimimitoceras hoennense Korn, 1993 from bed 9 of Mfis. A - MB.C.3823.4, $\times 3$. B - MB.C. 3823.2 at $\mathrm{dm}=12.4 \mathrm{~mm}$, ww $=8.3 \mathrm{~mm}, \times 5 . \mathbf{C}-$ MB.C. $3823.1 \mathrm{at} \mathrm{dm}=17.6 \mathrm{~mm}$, $\mathrm{wh}=10.5 \mathrm{~mm}, \mathrm{ww}=11.1 \mathrm{~mm}, \times 4.5$. D - Ontogenetic development of the whorl width index (ww/dm) and umbilical width index (uw/dm). E - Ontogenetic development of the whorl expansion rate (WER).

\section{Mimimitoceras Korn, 1988}

Type species. Mimimitoceras trizonatum Korn, 1988

\section{Mimimitoceras hoennense Korn, 1993}

Figs 6, 7 C, D

1960 Imitoceras liratum. - Vöhringer: 125, pl. 2: fig. 2.

* 1993 Mimimitoceras hoennense Korn: 585.

1994 Mimimitoceras hoennense. - Korn: 18, figs 19B, D, 20E, 21E, 22D.

2004 "Mimimitoceras" hoennense. - Becker \& Weyer: 8, figs 3a, 5c, 14-16.

Holotype. Specimen IGT 1130/18 (coll. Vöhringer).
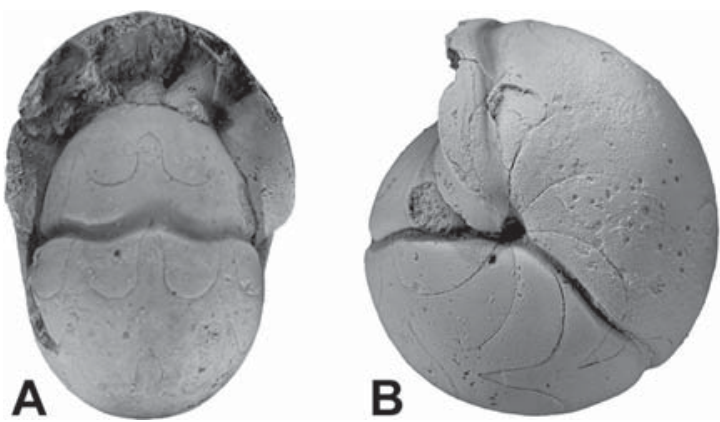

Fig. 7. Species of Mimimitoceras from bed 9 of Mfis. A, B - Mimimitoceras varicosum (Schindewolf, 1923), MB.C.3824.2, dorsal and lateral views, $\times$ 3. C, D - Mimimitoceras hoennense Korn, 1993, MB.C.3823.3, lateral and ventral views, $\times 3$.
Type locality and horizon. Railway cut near Ober-Rödinghausen (Rhenish Mountains, Germany); Hangenberg Limestone, bed 5 (Early Tournaisian, Acutimitoceras acutum Zone).

Material. 19 steinkern specimens from bed 9, of which 12 are well preserved, between 3 and $16 \mathrm{~mm}$ conch diameter. Five of these are preserved with body chamber.

Description. Specimen MB.C.3823.4 has a pachyconic conch $(\mathrm{ww} / \mathrm{dm}=0.83)$ at $4 \mathrm{~mm}$ conch diameter; at $9 \mathrm{~mm}$ diameter this ratio is reduced to 0.75 (Fig. 6A). The conch is thickest near the umbilicus and the flanks converge towards the broadly rounded venter. All stages larger than $2 \mathrm{~mm}$ conch diameter show a very narrow umbilicus $(\mathrm{uw} / \mathrm{dm}=0.03-0.06)$.
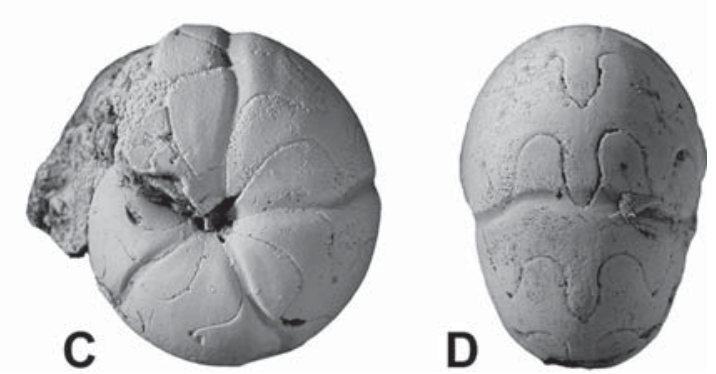
Remains of the shell are not preserved; specimen MB.C.3823.3 shows, at $13 \mathrm{~mm}$ diameter, five well-developed, slightly biconvex constrictions (Fig. 7C).

A suture line was drawn from specimens MB.C.3823.1 (Fig. 6C) and MB.C.3823.2 (Fig. 6B) at $17 \mathrm{~mm}$ and $12 \mathrm{~mm}$ diameter, respectively. The external lobe is slightly pouched in the first and parallel-sided in the second specimen. The ventrolateral saddle is rounded and has the same width as the adventive lobe. This lobe is symmetric, wide and $\mathrm{V}$-shaped with slightly curved flanks. External lobe and adventive lobe have the same depth.

Discussion. The species differs from Mimimitoceras varicosum (Schindewolf, 1923) in the wider adventive lobe, which is very narrow in that species and in the slightly slender conch shape.

\section{Mimimitoceras varicosum (Schindewolf, 1923)}

Figs $7 \mathrm{~A}, \mathrm{~B}, 8$

* 1923 Postprolobites varicosus Schindewolf: 405, fig. 13b.

n 1929 Prionoceras varicosum. - Lange: 60, pl. 1: figs 13, $13 a$.

n 1952 Imitoceras varicosum. - Schindewolf: 294, pl. 2: figs 3,4 .
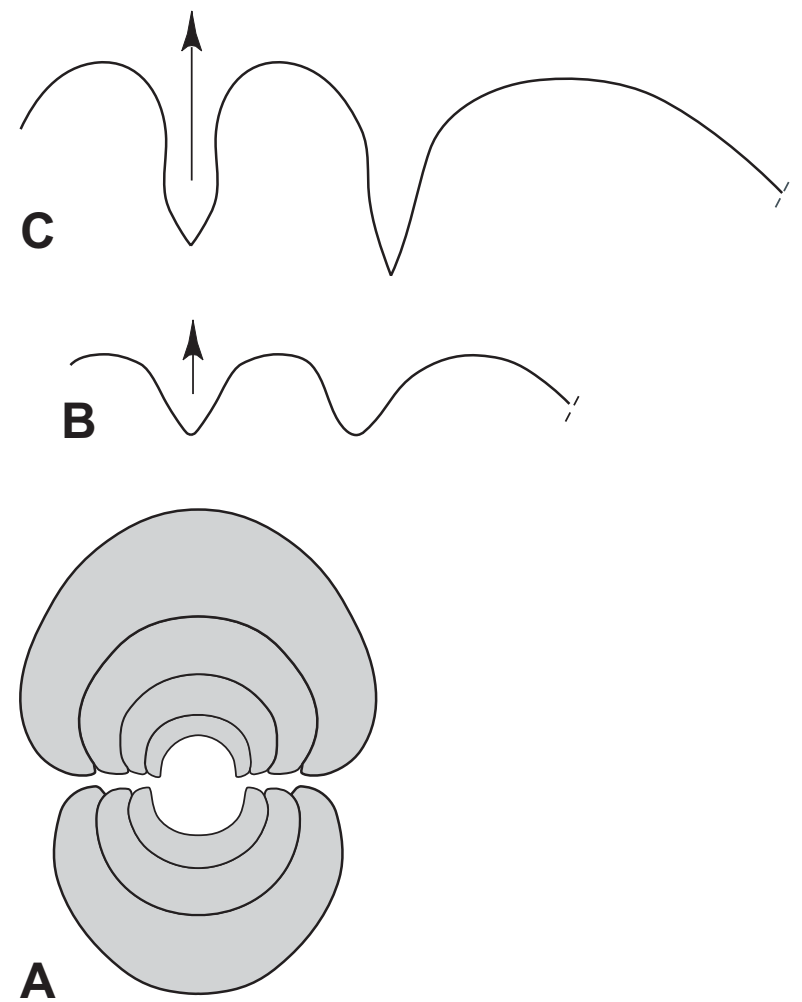

1960 Imitoceras varicosum. - Vöhringer: 122, pl. 2: fig. 1.

1977 Imitoceras varicosum. - Weyer: 170, pl. 2: fig. 2.

1992 Mimimitoceras varicosum. - Korn: 33, fig. 3.

1994 Mimimitoceras varicosum. - Korn: 22, figs 19A, C, 20C, D, 21F, 22C, 64E, F.

2004 "Mimimitoceras" varicosum. - Becker \& Weyer: 6, fig. 2a.

Holotype. Specimen MBG 4706 (coll. Schindewolf).

Type locality and horizon. Abandoned quarry of Gattendorf near Hof (Franconia, Germany); bed 21 (Early Tournaisian, Acutimitoceras acutum Zone).

Material. 12 steinkern specimens from bed 7 and 85 from bed 9 . The material from bed 7 is small (maximally $7 \mathrm{~mm}$ diameter); the material from bed 9 reaches $24 \mathrm{~mm}$ diameter. Body chambers are frequently preserved.

Description. Young individuals have a globular conch. In the sectioned specimen MB.C.3824.1 (Fig. 8A) the ww/dm ratio reaches a value of 0.91 at $4.5 \mathrm{~mm}$ diameter. During ontogeny, the conch shape becomes pachyconic (ww/ $\mathrm{dm}=0.73$ at $\mathrm{dm}=14 \mathrm{~mm})$. Flanks and venter are broadly rounded. The umbilicus is narrow (uw $/ \mathrm{dm}=0.03$ at $\mathrm{dm}=11 \mathrm{~mm}$ ) in all stages in this specimen.

Specimens such as MB.C.3824.2 (Fig.7A, B) and MB.C.3824.4 possess three conspicuous, slightly biconvex steinkern constrictions. They begin at the umbilicus and form a shallow sinus on the venter. The characteristic lip aperturally adjacent to the constrictions is visible in some of
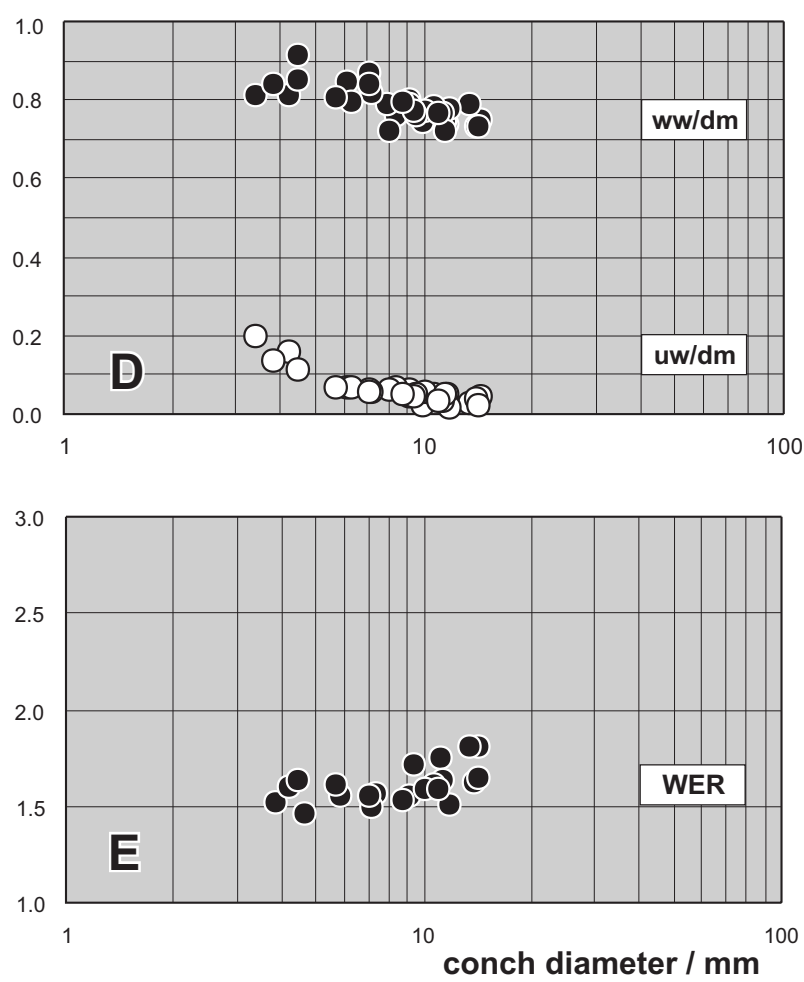

Fig. 8. Cross section (A), suture lines (B, C) and bivariate plots (D, E) of Mimimitoceras varicosum (Schindewolf, 1923) from bed 9 of Mfis. A - MB.C.3824.1, × 3. B - MB.C.3824.3 at ww =1.6 mm, $\times 10$. C - MB.C.3824.2 at dm $=11.9 \mathrm{~mm}$, ww $=6.8 \mathrm{~mm}, \times 6 . \mathbf{D}-$ Ontogenetic development of the whorl width index (ww/dm) and umbilical width index (uw/dm). $\mathbf{E}$ - Ontogenetic development of the whorl expansion rate (WER). 


\section{the specimens (MB.C.3824.2, Fig. 7A, MB.C.3824.5).}

Small specimens such as MB.C.3824.3 (Fig. 8B) show, at $4 \mathrm{~mm}$ conch diameter, a V-shaped external lobe and a closely resembling adventive lobe that is a little wider and has a blunt tip. At $12 \mathrm{~mm}$ diameter (MB.C.3824.2; Fig. 8C), the external lobe has parallel flanks, the ventrolateral saddle forms a rather wide and almost symmetric arc. The adventive lobe is very narrow and pointed in this stage; it is narrower than the external lobe and slightly deeper.

Discussion. Mimimitoceras hoennense Korn, 1993 has a similar, but more slender conch, and differs in the much wider adventive lobe.

\section{Paragattendorfia Schindewolf, 1924}

Type species. Paragattendorfia humilis Schindewolf, 1924

\section{Paragattendorfia aboussalamae n. sp.}

Figs 9, 10

Derivation of name. In honour of Zhor Sarah Aboussalam (Münster), who accompanied us on numerous successful field trips.
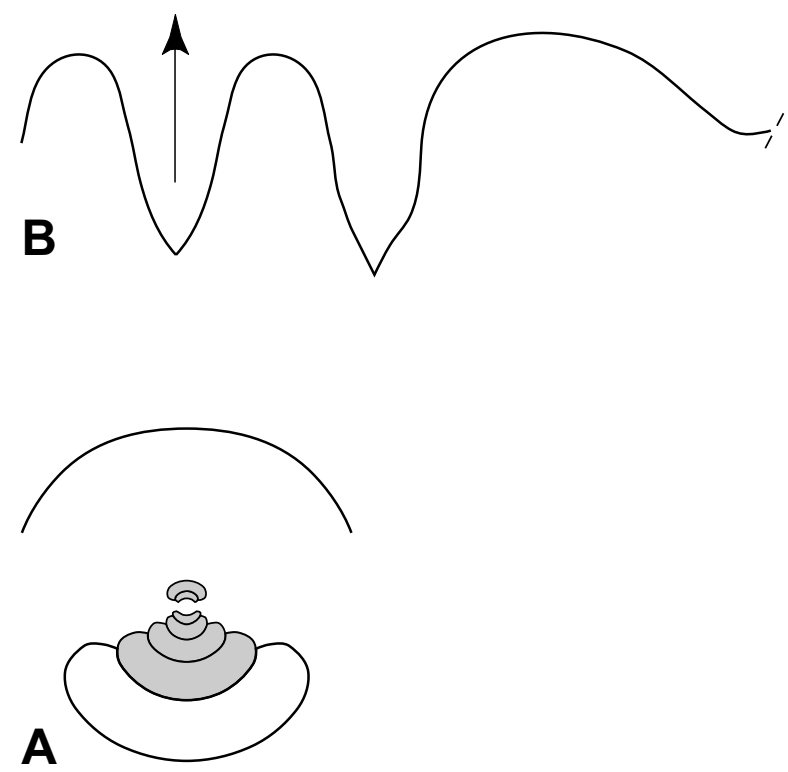

B, Holotype. MB.C.3825.1; figured here in Fig. 10A, B.

Type locality and horizon. Northern slope of the Jebel Debouaâ east of Mfis (Anti-Atlas, Morocco); bed 9 (Early Tournaisian).

Material. One well-preserved phragmocone (the holotype) and four additional, partly fragmentary specimens, all from bed 9 .

Description. Holotype MB.C.3825.1 (Fig. 10A, B) is a specimen with almost $14 \mathrm{~mm}$ diameter and has a globular conch (ww/dm $=0.96$ at $\mathrm{dm}=10 \mathrm{~mm}$ ). It shows a low aperture, reflected in a low whorl expansion rate of 1.57. The conch is widest at the pronounced umbilical edge. The umbilical wall stands vertically to the median plane; the moderate wide umbilicus, uw/dm $=0.27$ (Fig. 10A, B), opens stepwise. The specimen has two shallow steinkern constrictions, arranged at a distance of $180^{\circ}$. They extend in almost linear course across flanks and venter.

The suture line of the holotype (Fig. 9B) possesses, at $12 \mathrm{~mm}$ diameter, a V-shaped external lobe, a symmetrically rounded ventrolateral saddle and a pointed, V-shaped adventive lobe, that is a little narrower than the external lobe. The latter is slightly asymmetric with a flexed dorsal flank. The dorsolateral saddle is slightly higher than the symmetric ventrolateral saddle.
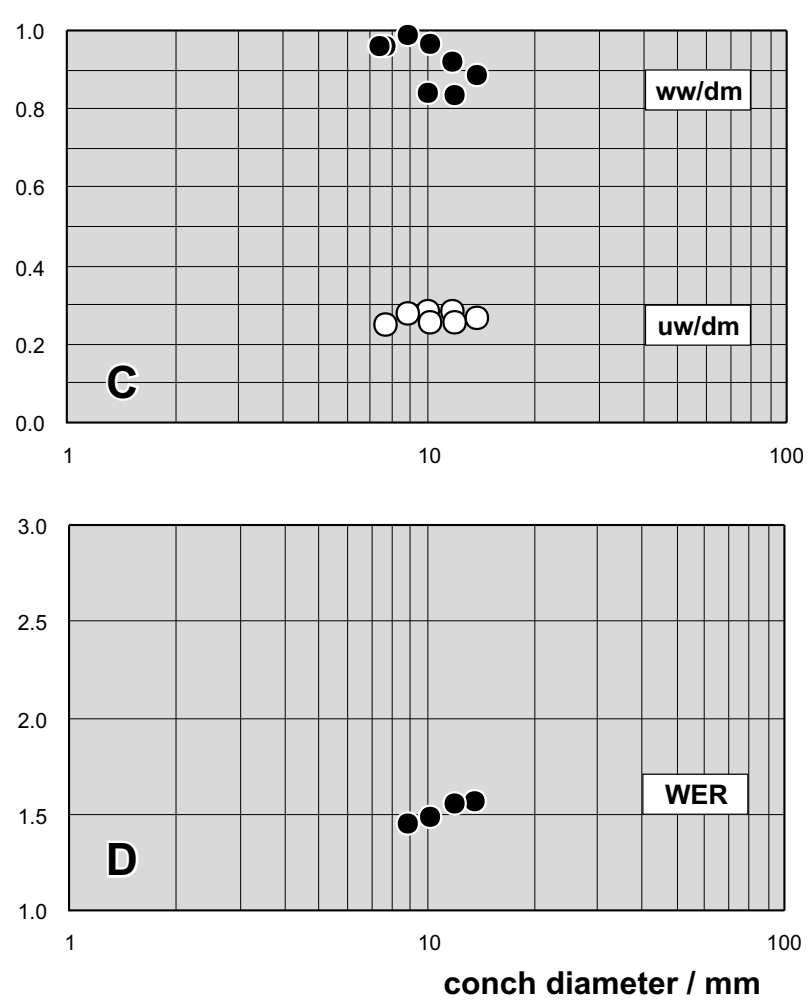

Fig. 9. Cross section (A), suture line (B) and bivariate plots (C, D) of Paragattendorfia aboussalamae n. sp. from bed 9 of Mfis. A - paratype MB.C.3825.4, $\times 3$. B - holotype MB.C.3825.1 at $\mathrm{dm}=12.1 \mathrm{~mm}, \mathrm{ww}=10 \mathrm{~mm}, \times 7.5$. C - Ontogenetic development of the whorl width index (ww/dm) and umbilical width index (uw/dm). D - Ontogenetic development of the whorl expansion rate (WER). 

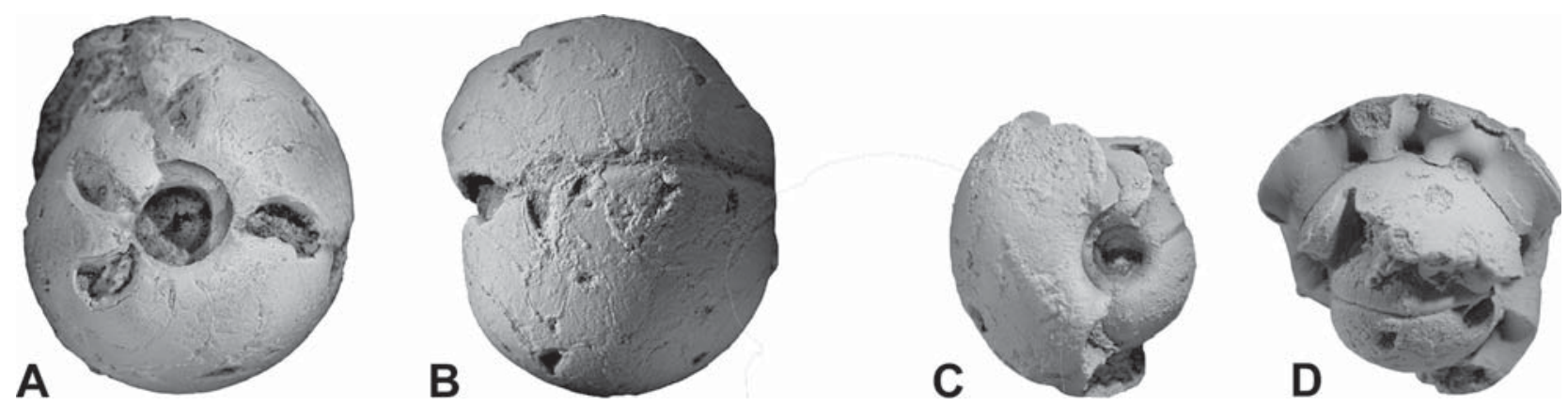

Fig. 10. Paragattendorfia aboussalamae n. sp. from bed 9 of Mfis. A, B - holotype MB.C.3825.1, lateral and ventral views, $\times$ 3. C, D - paratype MB.C.3825.5, lateral and dorsal views, $\times 3$.

Discussion. The new species closely resembles P. patens (Vöhringer, 1960) in its conch shape but differs from that species in the presence of steinkern constrictions.

\section{Subfamily Acutimitoceratinae Korn, 1994}

Discussion. The subdivision of the genus Acutimitoceras Librovich, 1957 into genera and subgenera, Acutimitoceras sensu stricto, Stockumites Becker, 1996, Streeliceras Becker, 1996, Sulcimitoceras Kuzina, 1985 and Nicimitoceras Korn, 1993, is doubtful and discussed in literature (Becker 1996; Korn in Korn \& Klug 2002; Becker \& Weyer 2004). Becker (1996) proposed Stockumites and Streeliceras as subgenera of Acutimitoceras; the validity of Sulcimitoceras was questioned. Acutimitoceras sensu stricto was limited to species with acute venter and evolute inner whorls, which were regarded as ancestors of Voehringerites Manger, 1971. All species with a rounded venter were classified as Stockumites; this subgenus contains species such as A. antecedens, which, according to Vöhringer, are interpreted as beeing ancestors of Gattendorfia Schindewolf, 1920. Discus-shaped, oxyconic species with lanceolate, shortened external lobe and evolute inner whorls were regarded as a specialized side-branch of Acutimitoceras and subsumed in the subgenus Streeliceras. Nicimitoceras was seen as homeomorph with Streeliceras.

Korn in Korn \& Klug (2002) treated Stockumites Becker, 1996 as a synonym of Acutimitoceras Librovich, 1957 and Streeliceras Becker, 1996 as a synonym of Nicimitoceras Korn, 1993. This problem was already mentioned earlier by Weyer (1976: 846), who extensively discussed the importance of sphenoid conch shape in the context of phylogenetic lineages and reached the conclusion that the oxyconic venter represents only a marginal morphology. We follow the argumentation of Weyer and Korn.

\section{Acutimitoceras Librovich, 1957}

Type species. Imitoceras acutum Schindewolf, 1923

\section{Acutimitoceras hollardi n. sp.}

Figs 11, 12

Derivation of name. After Henri Hollard, in honour of his important contributions to the knowledge of the geology of Morocco.

Holotype. MB.C.3827.1; figured here in Fig. 12C, D.

Type locality and horizon. Northern slope of the Jebel Debouaâ east of Mfis (Anti-Atlas, Morocco); bed 9 (Early Tournaisian).

Material. Two specimens from bed 9, the very well-preserved holotype and a fragment; one well-preserved specimen from bed 7 (MB.C.3817, Fig. 12A, B).

Diagnosis. Species of Acutimitoceras with thickly discoidal conch $(\mathrm{ww} / \mathrm{dm}=0.55$ at $\mathrm{dm}=12 \mathrm{~mm})$. Inner whorls up to $5 \mathrm{~mm}$ diameter with open umbilicus (uw $/ \mathrm{dm}=0.15-0.30$ ), umbilicus slightly open at $12 \mathrm{~mm}$ diameter. Aperture low, whorl expansion rate lower than 1.70 in stages larger than $5 \mathrm{mmn}$ diameter. Steinkern without constrictions. Suture line with narrow, lanceolate external lobe and V-shaped, very shallow, narrowly rounded adventive lobe.

Description. The sectioned paratype MB.C.3827.2 (Fig. 11A) shows the ontogeny between 2 and $9 \mathrm{~mm}$ conch diameter. All stages show similar discocone geometry, with the exception that the umbilicus becomes continuously smaller. An uw/dm ratio of 0.27 at $\mathrm{dm}=2.5 \mathrm{~mm}$ is reduced to 0.07 at $\mathrm{dm}=8.6 \mathrm{~mm}$. All stages show a rather low aperture with a whorl expansion rate between 1.55 and 1.70 .

The holotype is thickly discoidal (ww/dm $=0.53$ ); it is a smooth steinkern specimen without constrictions. The umbilicus is not completely closed $(\mathrm{uw} / \mathrm{dm}=0.06)$ with an oblique umbilical wall. Impressions of the growth lines are barely visible, their course is linear. All septa are widely spaced; five septa can be counted on half a volution.

The suture line of the holotype (Fig. 11B) shows the characteristically dissimilar external 

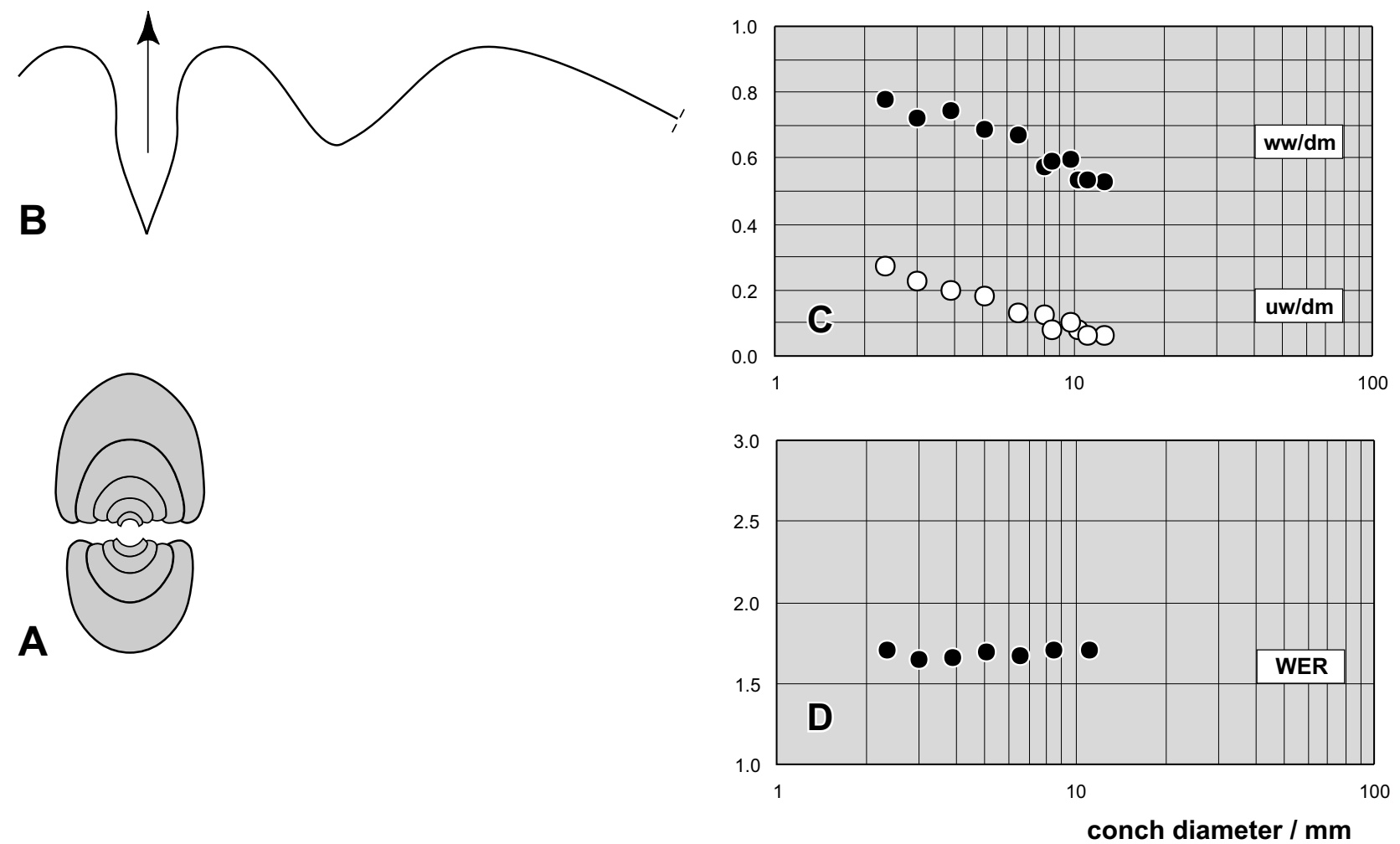

Fig. 11. Cross section (A), suture line (B) and bivariate plots (C, D) of Acutimitoceras hollardi n. sp. from bed 9 of Mfis. A paratype MB.C.3827.2, $\times 3$. B - holotype MB.C.3827.1 at wh $=4.2 \mathrm{~mm}$, ww $=4.9 \mathrm{~mm}, \times 10 . \mathbf{C}-$ Ontogenetic development of the whorl width index (ww/dm) and umbilical width index (uw/dm). D - Ontogenetic development of the whorl expansion rate (WER).

and adventive lobes. At $12 \mathrm{~mm}$ diameter there is a deep lanceolate external lobe and a half as deep, broadly $\mathrm{V}$-shaped and narrowly rounded adventive lobe. Both flanks of the adventive lobe are arranged almost exactly perpendicularily.

Discussion. The new species is characterised by the extremely shallow adventive lobe that separates it from all of the known species of the genus.

\section{Acutimitoceras intermedium (Schindewolf, 1923)} Figs 13, 14

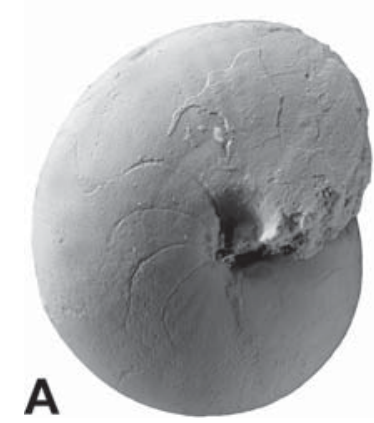

B

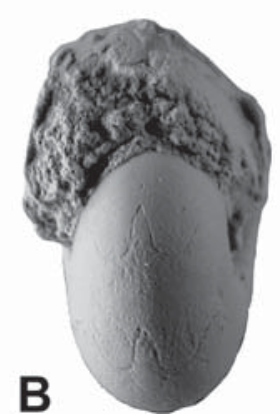

Fig. 12. Acutimitoceras hollardi n. sp. from bed 7 and bed 9 of Mfis. A, B - paratype MB.C.3817, lateral and dorsal views, from bed $7, \times 4$. C, D - holotype MB.C.3827.1, dorsal and lateral views from bed $9, \times 4$.
* 1923 Imitoceras intermedium Schindewolf: 333, pl. 16 : fig. 2.

p 1924 Aganides infracarbonicus. - Schmidt: 149, pl. 8: figs $1,2$.

1925 Aganides intermedius. - Schmidt: 532, pl. 19: fig. 2.

n 1952 Imitoceras intermedium. - Schindewolf: 291, figs $4-6$.

1960 Imitoceras intermedium. - Vöhringer: 131, pl. 3: figs $2,7,8$.

1977 Imitoceras intermedium. - Weyer: 177, fig. 2/1.

1981 Imitoceras (Imitoceras) intermedium. - Ruan: 64, pl. 12: figs 1-6, 9-13, 17-28.

1984 Acutimitoceras intermedium. - Korn: 75, pl. 3: figs $20-23$.

1994 Acutimitoceras intermedium. - Korn: 47, figs 37A-C, $40 \mathrm{C}, 41 \mathrm{~A}-\mathrm{E}, 44 \mathrm{~A}-\mathrm{C}, 45 \mathrm{~A}-\mathrm{C}, 47 \mathrm{~B}, 48 \mathrm{~A}, \mathrm{~B}, 56 \mathrm{D}-\mathrm{F}$, $57 \mathrm{~B}, \mathrm{C}$.

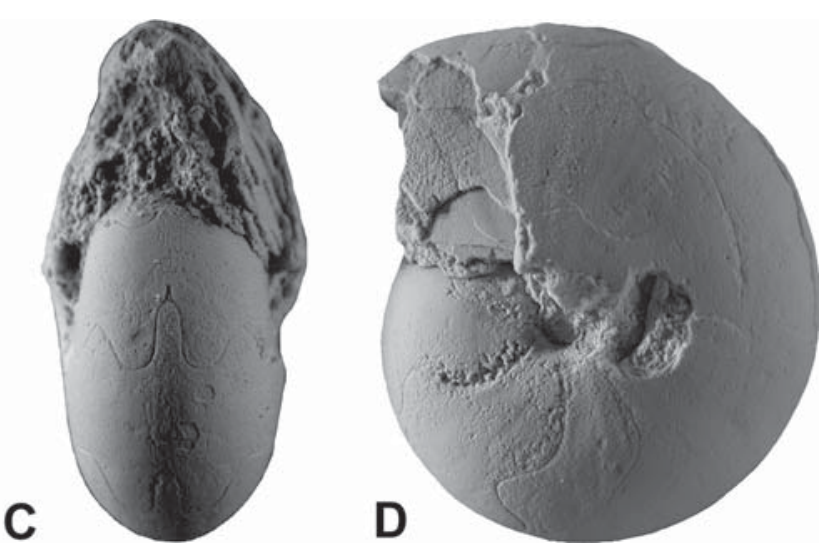



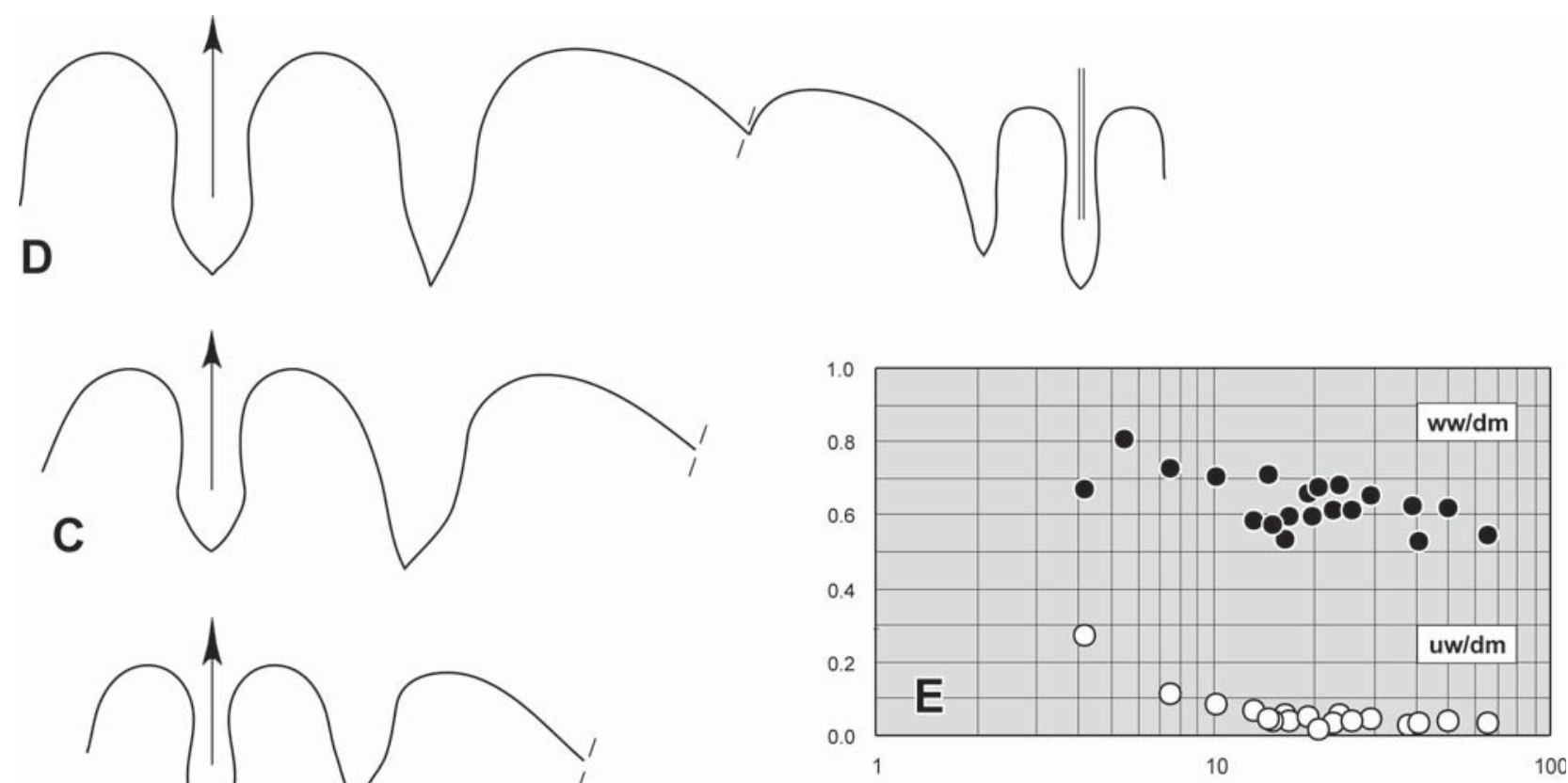

B
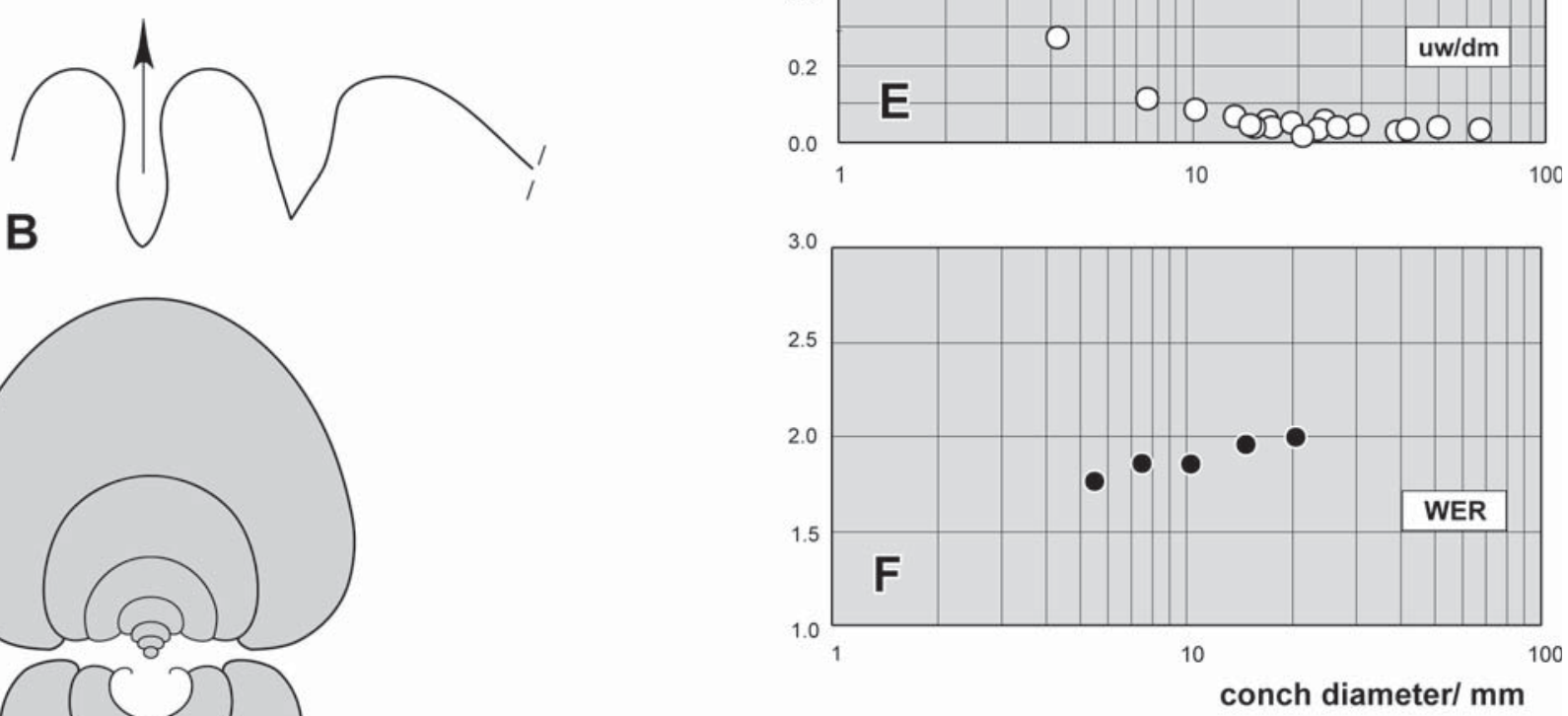

A

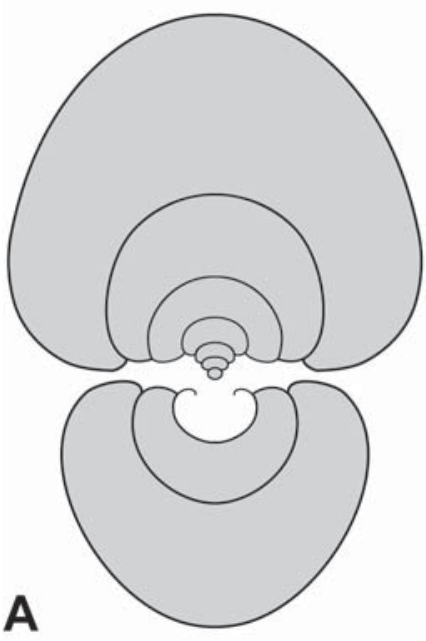

conch diameter/ $\mathrm{mm}$

Fig. 13. Cross section (A), suture lines (B - D) and bivariate plots (E, F) of Acutimitoceras intermedium (Schindewolf, 1923) from bed 1c and bed 2 of Mfis. A - MB.C.3807.3 from bed 1c, $\times 3$. B - MB.C.3807.1 from bed 1c, at $\mathrm{dm}=25 \mathrm{~mm}$, $\mathrm{ww}=15.4 \mathrm{~mm}, \times 2.5$. C - MB.C.3813.3 from bed 2, at $\mathrm{dm}=30 \mathrm{~mm}$, ww $=23.7 \mathrm{~mm}, \times 2 . \mathbf{D}-$ MB.C.3813.1 from bed 2, at $\mathrm{dm}=46 \mathrm{~mm}, \mathrm{ww}=29.7 \mathrm{~mm}, \times 2 . \mathbf{E}-$ Ontogenetic development of the whorl width index (ww/dm) and umbilical width index (uw/dm). F - Ontogenetic development of the whorl expansion rate (WER).
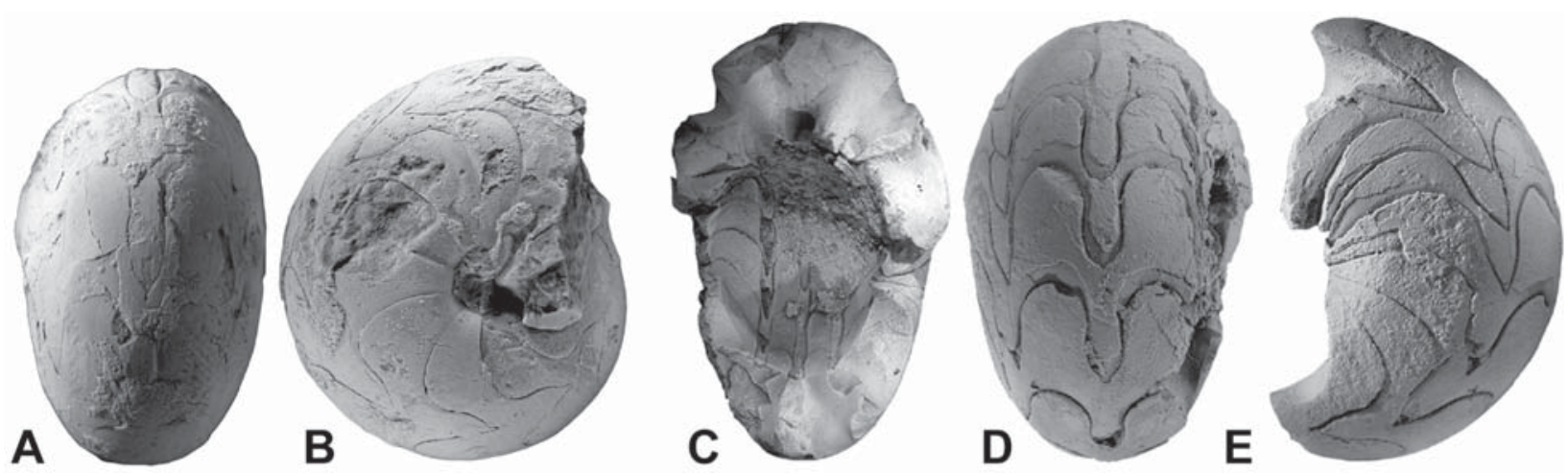

Fig. 14. Acutimitoceras intermedium (Schindewolf, 1923) from bed 1c and bed 2 of Mfis. A, B - MB.C.3807.1, ventral and lateral views, from bed 1c, $\times$ 1.5. C, D, E - MB.C.3813.1, dorsal, ventral and lateral views, from bed $2, \times 1$. 
Holoty pe. Specimen MBG 3111 (coll. Schindewolf).

Type locality and horizon. Abandoned quarry of Gattendorf near Hof (Franconia, Germany); bed 21 (Early Tournaisian, Acutimitoceras acutum Zone).

Material. 16 limonitic specimens up to $37 \mathrm{~mm}$ diameter from bed 1c, two of which are well-preserved phragmocones; five large sideritic specimens from bed 2, one beeing a wellpreserved fragment.

Description. Specimen MB.C.3807.3 (Fig. 13A) was sectioned; it is thickly pachyconic at $5 \mathrm{~mm}$ diameter $(\mathrm{ww} / \mathrm{dm}=0.81)$ and thinly pachyconic at $20 \mathrm{~mm}$ diameter $(\mathrm{ww} / \mathrm{dm}=0.67)$. Within this growth interval, the umbilical width ratio is reduced from 0.27 to 0.02 . The flanks are always broadly rounded and the whorl cross section is almost circular throughout ontogeny.

Specimen MB.C.3813.2 confirms this. It is a specimen that does not show steinkern constrictions, but the steinkern bears indications of convex growth lines; such growth lines are only patchily preserved around the umbilicus, they are sharp and fine.

The suture line of specimen MB.C.3813.1 (Fig. 13D) has a lanceolate external lobe and an almost symmetric ventrolateral saddle that has twice the width of the rather narrow adventive lobe. This is slightly deeper than the external lobe and has weakly sinuous flanks.
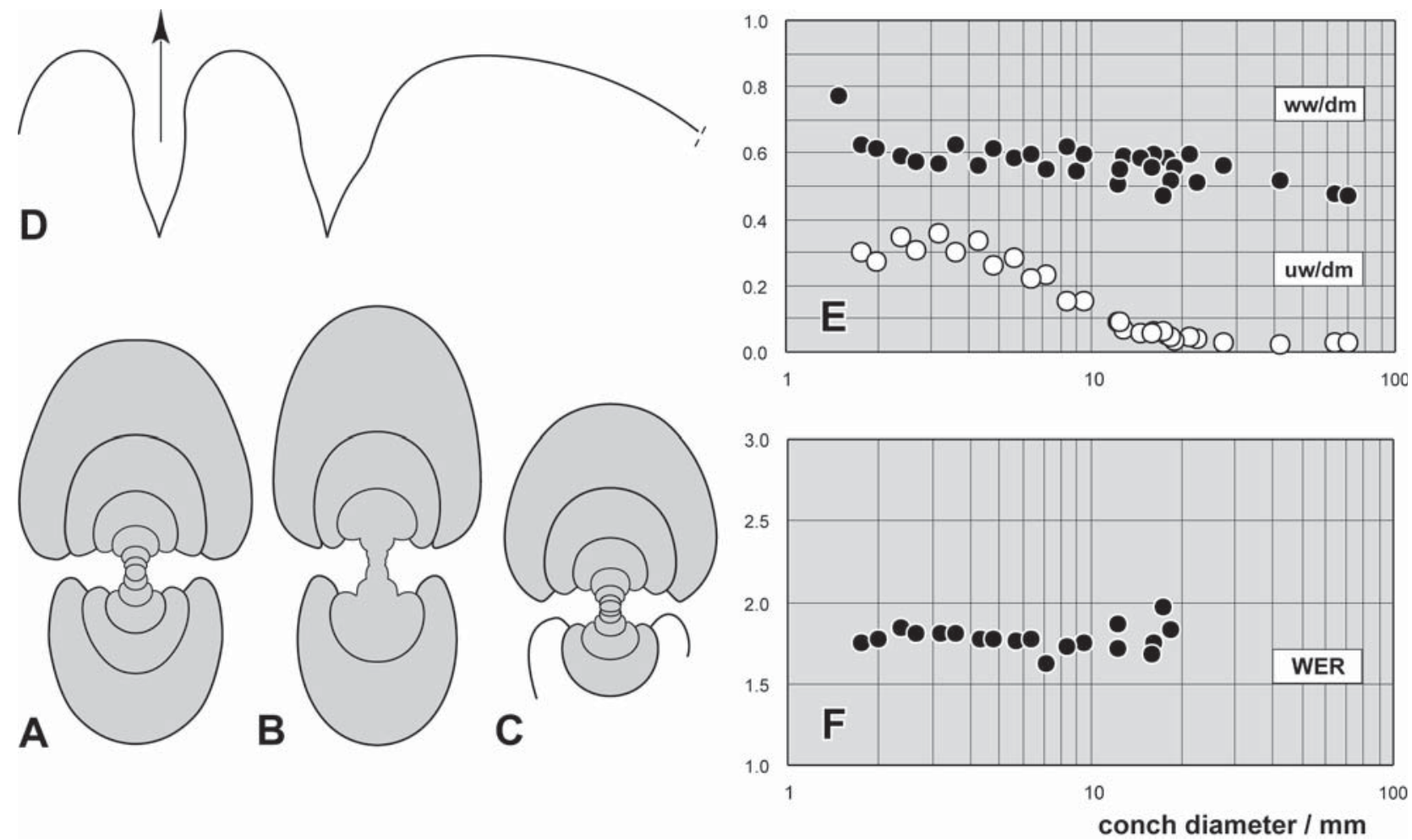

Fig. 15. Cross sections $(\mathrm{A}-\mathrm{C})$, suture line (D) and bivariate plots (E, F) of Acutimitoceras subbilobatum (Münster, 1839), from bed 1c of Mfis. A - MB.C.3809.5, × 3. B - MB.C.3809.3, × 3. C - MB.C.3809.4, × 3. D - MB.C.3809.2 at $\mathrm{dm}=19.4 \mathrm{~mm}, \mathrm{ww}=10.3 \mathrm{~mm}, \times 4 . \mathbf{E}-$ Ontogenetic development of the whorl width index (ww $/ \mathrm{dm})$ and umbilical width index (uw/dm). F - Ontogenetic development of the whorl expansion rate (WER). 

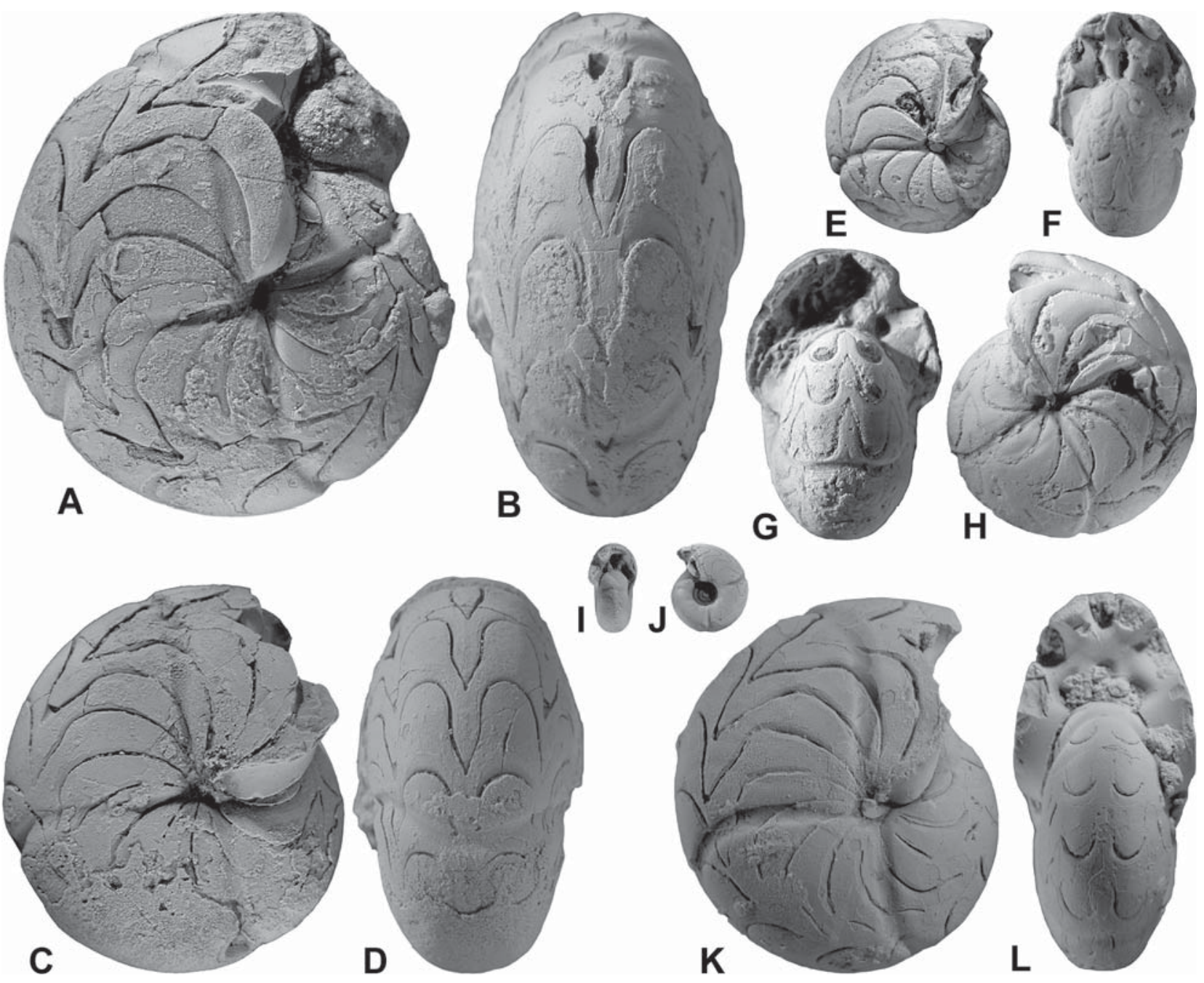

Fig. 16. Species of Acutimitoceras from bed 1c and bed 9 of Mfis. A, B - Acutimitoceras subbilobatum (Münster, 1839), MB.C.3809.1 from bed 1c, lateral and ventral views, $\times$ 2.5. C, D - Acutimitoceras subbilobatum (Münster, 1839), MB.C.3809.2 from bed 1c, lateral and ventral views, $\times 2.5$. E, F - Acutimitoceras posterum n. sp., paratype MB.C.3828.2 from bed 9, lateral and dorsal views, $\times 2.5$. G, H - Acutimitoceras posterum n. sp., holotype MB.C.3828.1 from bed 9, dorsal and lateral views, $\times$ 2.5. I, J - Acutimitoceras mfisense n. sp., paratype MB.C.3829.5 from bed 9, dorsal and lateral views, $\times 3$. K, L - Acutimitoceras mfisense n. sp., holotype MB.C.3811.1 from bed 9, lateral and dorsal views, $\times 3$.

stages, the umbilical width stops increasing. Flanks and venter are broadly rounded and the conch is widest in the midflank area some distance from the umbilicus. At the maximum diameter of $16 \mathrm{~mm}$, the umbilicus is still slightly opened (uw/dm $=0.05$ ). The conch is thickly discoidal in all stages larger than $2 \mathrm{~mm}$ conch diameter $(\mathrm{ww} / \mathrm{dm}=0.55-0.60)$.

An intermediate-sized conch MB.C.3809.1 (Fig. 16A, B) is thickly discoidal at $27 \mathrm{~mm}$ diameter $(\mathrm{ww} / \mathrm{dm}=0.53)$. The flanks stand almost parallel to each other, and the venter is rounded. In this stage, height and width of the whorl are approximately the same. The rather well-preserved steinkern specimen shows four constrictions, which are not exactly arranged in distances of $90^{\circ}$; the last of these extends almost linear across the flanks and bends back to form a welldeveloped ventral sinus. Smaller specimens such as MB.C.3809.2 possess a shallower ventral sinus at $21 \mathrm{~mm}$ diameter. The material from bed 2 has the characteristic conch geometry, but the large specimens do not show constrictions.

The suture line of specimen MB.C.3809.2 (Fig. 15D) is characteristic for Acutimitoceras. There is a lanceolate, narrow external lobe, an asymmetric ventrolateral saddle and a V-shaped adventive lobe with slightly sinuous flanks.

Discussion. Within the assemblages from Mfis, A. subbilobatum is most similar to the new species $A$. posterum. This species, however, has a thicker conch and narrower external and adventive lobes.

\section{Acutimitoceras posterum n. sp.}

Figs $16 \mathrm{E}-\mathrm{H}, 17$ 
Derivation of name. From the Latin posterum = succeeding, because the species is regarded as a descendant of A. subbilobatum.

Holotype. MB.C.3828.1; figured here in Fig. 16G, H.

Type locality and horizon. Northern slope of the Jebel Debouaâ east of Mfis (Anti-Atlas, Morocco); bed 9 (Early Tournaisian).

Material. 112 steinkern specimens from bed 9, of which 55 are well-preserved. The maximal conch diameter is $21 \mathrm{~mm}$; all specimens are phragmocones.

Diagnosis. Species of Acutimitoceras with pachyconic conch $(\mathrm{ww} / \mathrm{dm}=0.60-0.70$ at $\mathrm{dm}=12 \mathrm{~mm})$. Inner whorls up to $5 \mathrm{~mm}$ diameter with open umbilicus (uw/dm $=0.20-0.42$ ), umbilicus slightly open at $12 \mathrm{~mm}$ diameter. Aperture moderate, whorl expansion rate $1.80-2.00$ in stages larger than $5 \mathrm{~mm}$ diameter. Steinkern with well-preserved constrictions. Suture line with narrow, lanceolate external lobe and narrow, V-shaped adventive lobe.

Description. Three specimens were sectioned (Fig. 17A-C); these display the conch ontogeny from the initial stage to a diameter of $13 \mathrm{~mm}$. All show the transition from the serpenticonic early juvenile stage to the pachyconic intermediate stage, in which the whorl cross section is almost circular. The conches are widest in the lower third of the flank area.

The holotype (Fig. 16G, H) is a fully septate specimen (12 septa per whorl) at $16 \mathrm{~mm}$ conch diameter; it is pachyconic $(\mathrm{ww} / \mathrm{dm}=0.66)$ with a closed umbilicus. It has four constrictions arranged $90^{\circ}$ apart. They run straight across the flanks and form a shallow ventral sinus.

The suture line of this specimen (Fig. 17D) has, at $15.5 \mathrm{~mm}$ conch diameter, a very narrow and deep external lobe with almost continuously diverging flanks, followed by a symmetric, broadly rounded ventrolateral saddle that is more than twice as wide as the external lobe and a rather narrow adventive lobe with slightly sinuous flanks. The dorsolateral saddle is broadly rounded and as high as the ventrolateral saddle.

Discussion. The new species shows close affinities to $A$. subbilobatum, but differs in the wider conch. At a diameter of $12 \mathrm{~mm}$, the ww/dm ratio is $0.50-0.60$ in $A$. subbilobatum and $0.60-0.70$ in $A$. posterum. This difference is supported by the development of the umbilical width, which differs in the new species in the much earlier closure of the umbilicus. A further criterion for the separation of the two species is the suture line; the new species has narrower lobes than A. subbilobatum.

\section{Acutimitoceras mfisense n. sp.}

Figs $16 \mathrm{I}-\mathrm{L}, 18$

Derivation of name. After the abandoned Mfis village, where the specimens were collected.
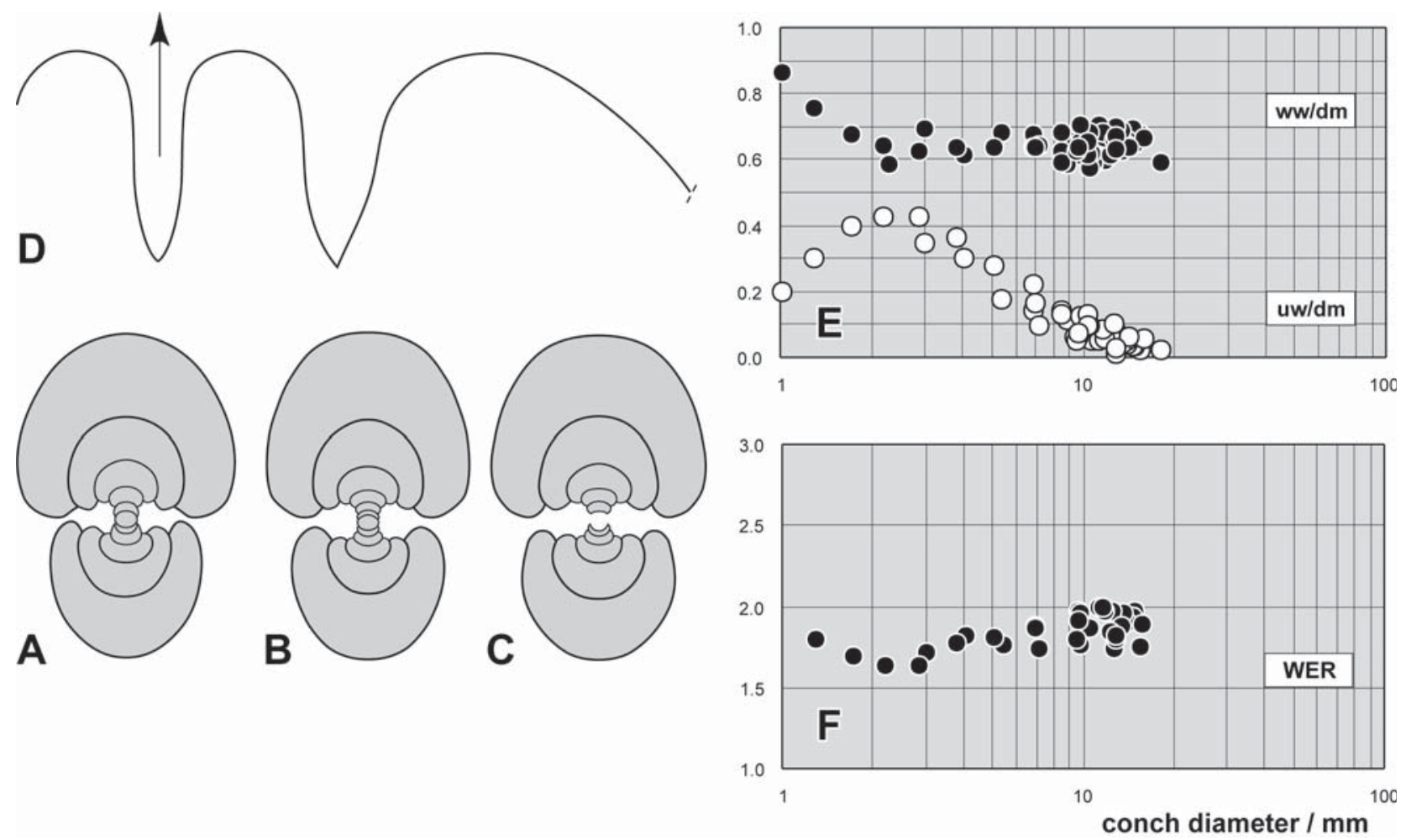

Fig. 17. Cross sections $(\mathrm{A}-\mathrm{C})$, suture line (D) and bivariate plots (E, F) of Acutimitoceras posterum n. sp. from bed 9 of Mfis. A - paratype MB.C.3828.2, × 3. B - paratype MB.C.3828.4, $\times 3$. C - holotype MB.C.3828.1, $\times 3$. D - holotype MB.C. 3828.1 at $\mathrm{dm}=16.5 \mathrm{~mm}, \mathrm{wh}=8.8 \mathrm{~mm}, \mathrm{ww}=10.4 \mathrm{~mm}, \times 5 . \mathbf{E}-$ Ontogenetic development of the whorl width index (ww/dm) and umbilical width index (uw/dm). F - Ontogenetic development of the whorl expansion rate (WER). 
Holotype. MB.C.3811.1; figured here in Fig. 16K, L.

Type locality and horizon. Northern slope of the Jebel Debouaâ east of Mfis (Anti-Atlas, Morocco); bed 1c (Early Tournaisian).

Material. It is the most abundant species in the assemblages from Mfis. A total of 148 well-preserved specimens are available for study; 48 specimens between 16 and $24 \mathrm{~mm}$ diameter are from bed $1 \mathrm{c}, 47$ very small specimens from bed 7 and 53 specimens from bed 9 .

Diagnosis. Species of Acutimitoceras with thickly discoidal conch $(\mathrm{ww} / \mathrm{dm}=0.44-0.56)$ at $12 \mathrm{~mm}$ diameter. Inner whorls with widely opened umbilicus (uw/dm $=0.50$ at $\mathrm{dm}$ $=2.5 \mathrm{~mm}$ ), umbilicus almost closed at $12 \mathrm{~mm}$ diameter. Aperture moderately high, whorl expansion rate 1.80-2.00, in stages larger than $10 \mathrm{~mm}$ diameter. Steinkern with strong constrictions. Suture line with lanceolate, slightly pouched external lobe and asymmetric, V-shaped adventive lobe. Adventive lobe deeper than the external lobe.
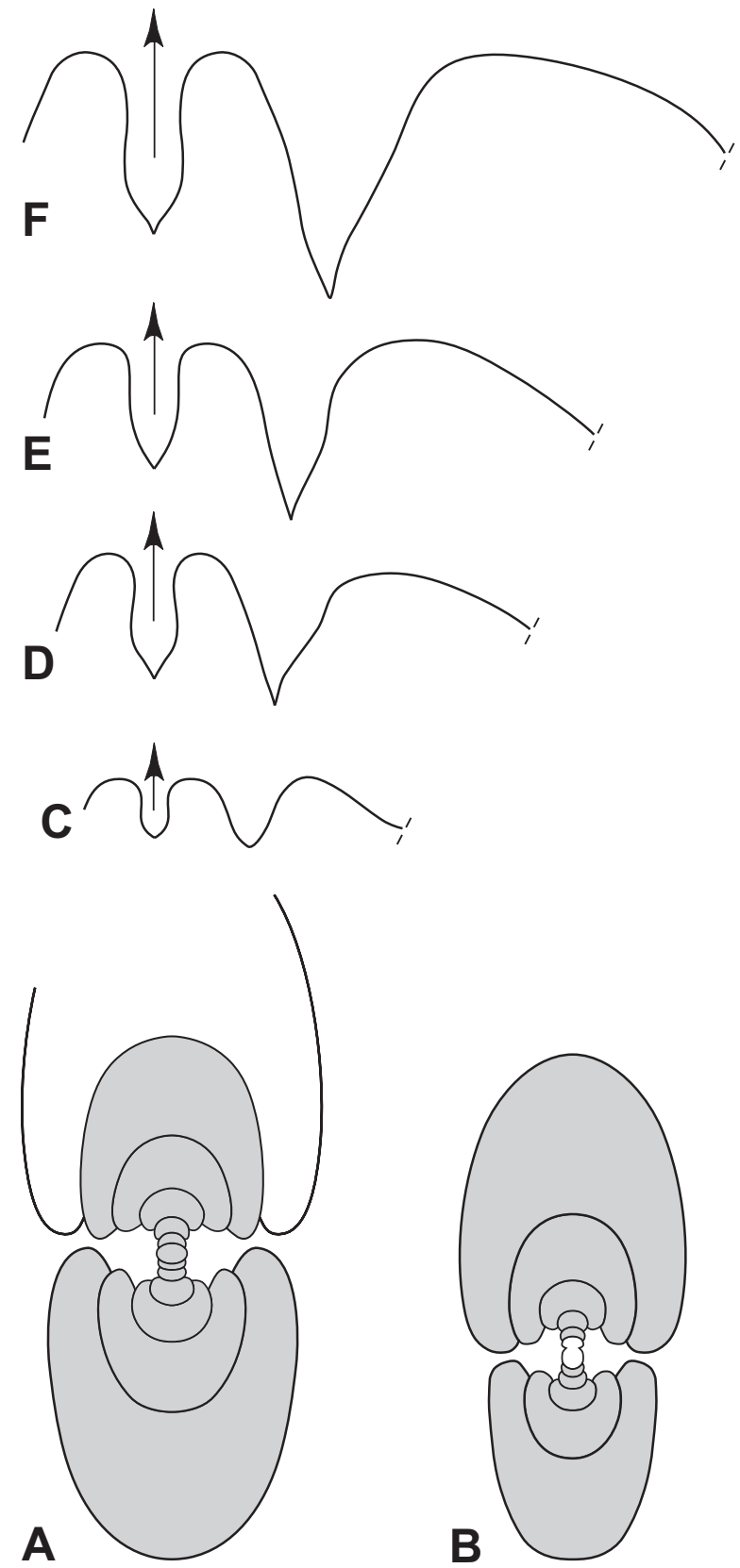

Description. Specimens MB.C.3811.2 and MB.C.3811.6 were sectioned (Fig. 18A, B); both show very similar conch proportions and four very widely umbilicate inner whorls, with a maximum uw/dm ratio of 0.50 at $\mathrm{dm}=2.5 \mathrm{~mm}$ conch. This is the stage in which the conch is very slender $(\mathrm{ww} / \mathrm{dm}=0.50)$ and has the lowest aperture $(\mathrm{WER}=1.55)$. Later in ontogeny, the umbilicus becomes rapidly smaller and is almost closed at $12 \mathrm{~mm}$ conch diameter. While the ww/ $\mathrm{dm}$ ratio does not display remarkable changes, the aperture becomes continuously higher. There is some variability within the assemblage; a whorl expansion rate of 2.00 is reached at $12 \mathrm{~mm}$ conch diameter. The whorl cross section is strongly compressed at a diameter of $18 \mathrm{~mm}$; the
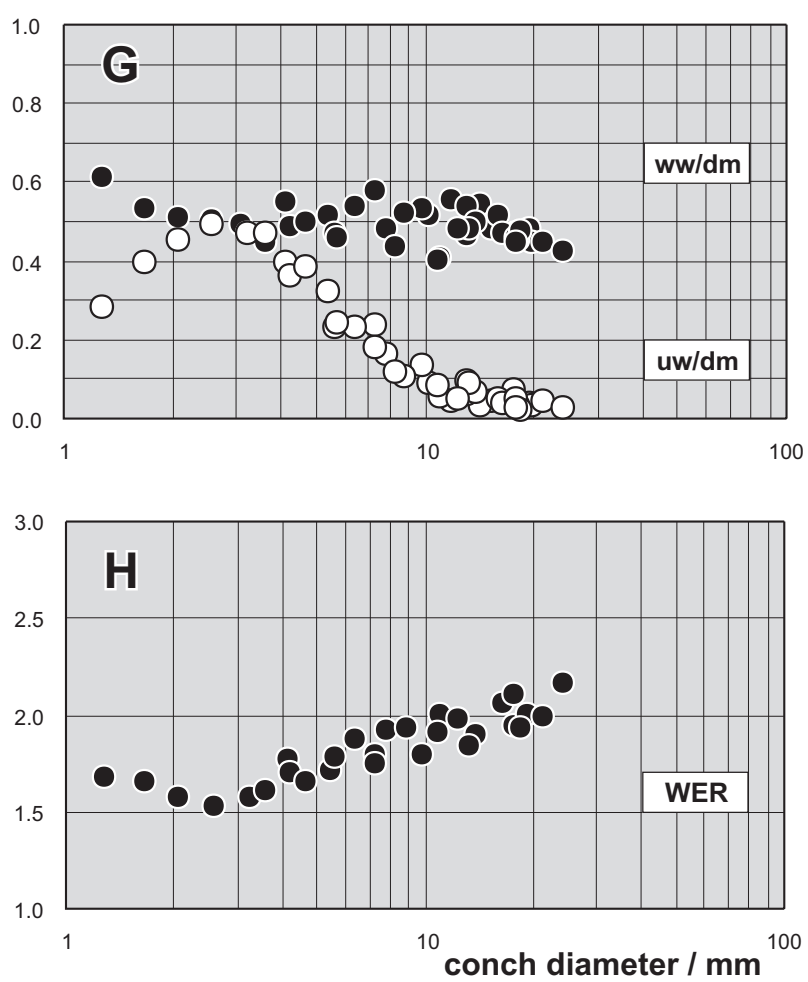

Fig. 18. Cross sections (A, B), suture lines $(\mathrm{C}-\mathrm{F})$ and bivariate plots $(\mathrm{G}, \mathrm{H})$ of Acutimitoceras mfisense n. $\mathrm{sp}$. from bed 1c and bed 9 of Mfis. A - paratype MB.C.3811.2 from bed 1c, $\times 3$. B - paratype MB.C.3811.6 from bed 1c, $\times 3$. C - paratype MB.C.3829.5 from bed 9, at $\mathrm{dm}=4.1 \mathrm{~mm}$, $\mathrm{ww}=2.1 \mathrm{~mm}, \times 12 . \mathbf{D}$ - paratype MB.C.3811.3 from bed $1 \mathrm{c}$, at $\mathrm{dm}=13.5 \mathrm{~mm}, \quad w w=6.5 \mathrm{~mm}, \times 4 . \mathbf{E}$ - holotype MB.C. 3811.1 from bed $1 \mathrm{c}$, at $\mathrm{dm}=16.3 \mathrm{~mm}$, ww $=7.9 \mathrm{~mm}$, $\times$ 4. F - paratype MB.C.3811.2 from bed 1c, at $\mathrm{ww}=9.1 \mathrm{~mm}, \times 4 . \mathbf{G}-$ Ontogenetic development of the whorl width index (ww/dm) and umbilical width index (uw/ $\mathrm{dm})$. $\mathbf{H}$ - Ontogenetic development of the whorl expansion rate (WER). 
conch is widest in the midflank area, with parallel flanks.

Holotype MB.C.3811.1 (Fig. 16K, L) is discoidal at $17.5 \mathrm{~mm}$ conch diameter $(\mathrm{ww} / \mathrm{dm}=0.47)$; the conch is thickest in the midflank area. The flanks are almost parallel and converge slowly to the rounded venter. The fully septate specimen lacks ornament except for the four constrictions that are arranged in distances of approximately $90^{\circ}$. They are linear on the flanks and turn back to form a rather deep, narrow ventral sinus. The last volution has 15 septa.

In the suture line of the holotype (Fig. 18E), drawn at $16 \mathrm{~mm}$ conch diameter, the lanceolate external lobe has only $75 \%$ of the depth of the adventive lobe. This adventive lobe is asymmetrically V-shaped with a slightly sinuous dorsal flank. The suture line of the larger paratype MB.C.3811.2 (Fig. 18F) at $9 \mathrm{~mm}$ whorl width (corresponding to appr. $18 \mathrm{~mm}$ conch diameter) is similar, except for the more sinuous ventral flank of the adventive lobe.
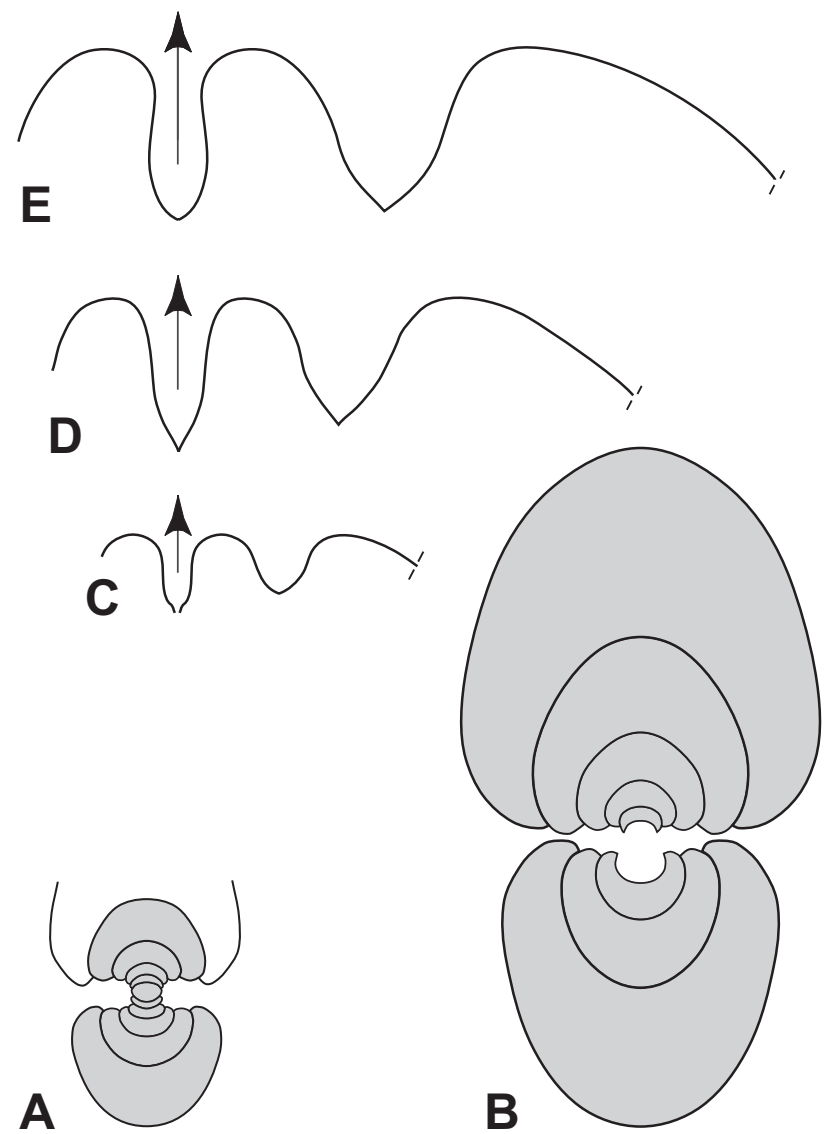

Fig. 19. Cross sections (A, B), suture lines $(\mathrm{C}-\mathrm{E})$ and bivariate plots $(\mathrm{F}, \mathrm{G})$ of Acutimitoceras occidentale $\mathrm{n}$. sp. from bed 1c and bed 9 of Mfis. A - paratype MB.C.3826.4 from bed 9, × 3. B - paratype MB.C.3810.6 from bed 1c, $\times 3$. C - paratype MB.C. 3826.4 from bed 9 , at $\mathrm{dm}=7.6 \mathrm{~mm}, w w=4.9 \mathrm{~mm}, \times 5 . \mathbf{D}-$ paratype MB.C. 3810.3 from bed $1 \mathrm{c}$, at $\mathrm{dm}=15 \mathrm{~mm}$, $\mathrm{ww}=8.7 \mathrm{~mm}, \times 3.5$. E - holotype MB.C. 3810.1 from bed $1 \mathrm{c}$, at $\mathrm{dm}=24.8 \mathrm{~mm}, \mathrm{ww}=13.3 \mathrm{~mm}, \times 3$. F - Ontogenetic development of the whorl width index (ww/dm) and umbilical width index (uw/dm). G - Ontogenetic development of the whorl expansion rate (WER).
Discussion. A. mfisense resembles some species of Nicimitoceras but differs in the presence of the strong steinkern constrictions that are not known from that genus. The new species belongs to the very widely umbilicate species of the genus and is separated by its short external lobe from similar species such as A. subbilobatum.

\section{Acutimitoceras occidentale $\mathbf{n}$. sp.}

Figs 19, 20 West, because of the occurrence in the western part of North Africa.

Holoty pe. MB.C.3810.1; figured here in Fig. 20A, B.

Type locality and horizon. Northern slope of the Jebel Debouaâ east of Mfis (Anti-Atlas, Morocco); bed 1c (Early Tournaisian).

Material. 33 well-preserved steinkern specimens up to $39 \mathrm{~mm}$ conch diameter from bed 1c and four well preserved small specimens ( 3.8 to $9.4 \mathrm{~mm} \mathrm{dm}$ ) from bed 9 .
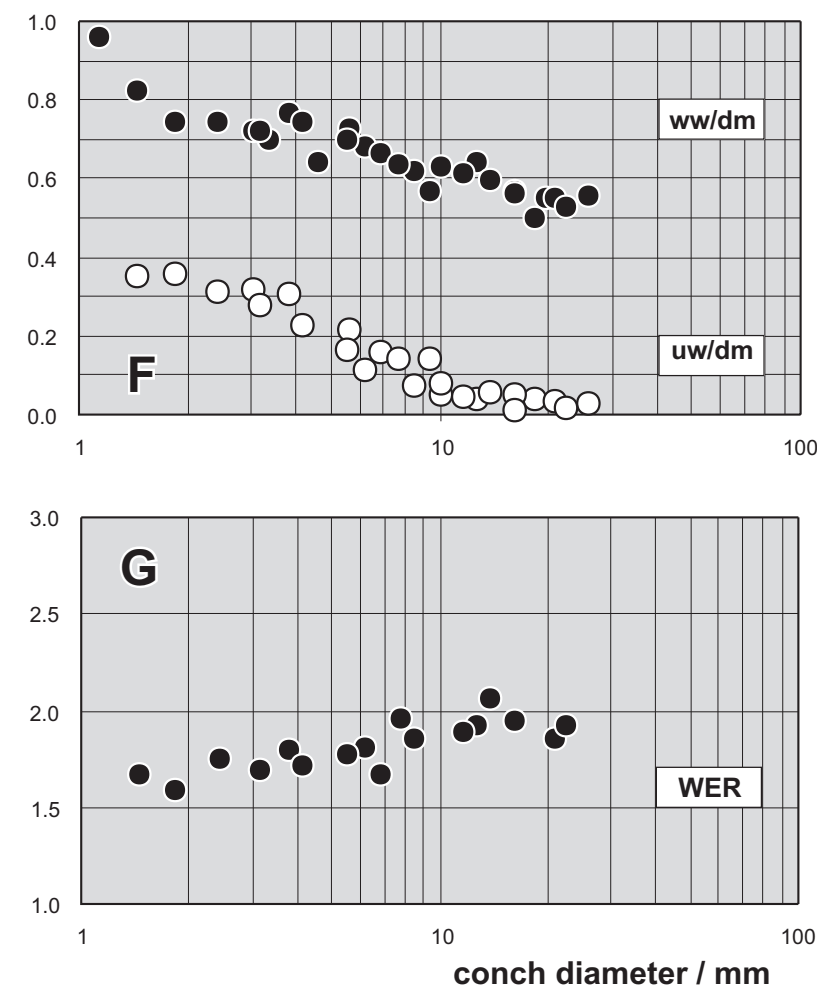

Derivation of name. From the Latin occidens $=$ the 
Diagnosis. Species of Acutimitoceras with pachyconic conch $(\mathrm{ww} / \mathrm{dm}=0.60-0.65)$ at $12 \mathrm{~mm}$ diameter. Inner whorls up to $5 \mathrm{~mm}$ diameter with open umbilicus (uw/dm $=0.20-0.35$ ), umbilicus almost closed at $12 \mathrm{~mm}$ diameter. Aperture moderately high, whorl expansion rate $1.80-2.00$ in stages larger than $10 \mathrm{~mm}$ diameter. Steinkern without constrictions, in the early stage with weak biconvex riblets that are bifurcate in the midflank area. Suture line with narrow, slightly pouched external lobe and narrow, V-shaped adventive lobe.

Description. The two cross sections MB.C.3826.4 (Fig. 19A) and MB.C.3810.6 (Fig. 19B) allow the study of the conch ontogeny from the earliest stage to a diameter of $22.5 \mathrm{~mm}$. Characteristic for Acutimitoceras are the widely umbilicate inner whorls which embrace the preceding to a minor degree. The relative width of the umbilicus has its maximum value at $2 \mathrm{~mm}$ diameter $(\mathrm{uw} / \mathrm{dm}=0.40)$, thereafter a continuous lowering can be seen. The umbilicus is closed in stages larger than $10 \mathrm{~mm}$ conch diameter. Another ontogenetic trend is the lowering of the ww/dm ratio; the pachyconic conch at $4 \mathrm{~mm}$ diameter (ww/dm $=0.70-0.80)$ is transformed into a thickly discoidal conch at $20 \mathrm{~mm}$ diameter $(\mathrm{ww} / \mathrm{dm}=0.50-0.60)$.

The well-preserved holotype MB.C.3810.1 (Fig. 20A, B) shows the conch morphology at $26 \mathrm{~mm}$ diameter. It is thickly discoidal (ww/dm
$=0.56)$ with closed umbilicus and a moderately high aperture (WER =1.95). The umbilicus is funnel-shaped with a visible edge, bordering the flanks; the umbilical wall is oblique. The conch is thickest at the umbilical edge, from where the flanks converge towards the rounded venter. This steinkern is smooth except for some impressions of biconvex growth lines, which appear to be periodically strengthened. There are no constrictions. The fully septate specimen has 15 septa on the last volution.

Medium and smaller specimens such as MB.C.3810.5 differ in ornament and suture line. At approximately $8 \mathrm{~mm}$ diameter, there are weak riblets visible on the steinkern. They extend with biconvex course across flanks and venter and display splitting and intercalation in the midflank area. This ornament disappears soon; the conch is smooth already at $12 \mathrm{~mm}$ diameter.

The four specimens from bed 9 are small. MB.C.3826.4 (Fig. 19A) has a pachyconic conch $(w w / d m=0.75$ at $d m=1.8 \mathrm{~mm}) ; w w / d m$ is reduced to 0.64 at $\mathrm{dm}=7.7 \mathrm{~mm}$. The umbilicus is widely opened in the juvenile stage (uw/dm $=0.36$ ) with a continuous closing to a value of 0.14 at $7.7 \mathrm{~mm}$ diameter. All specimens display equidistant, lamellar impressions of growth lines,
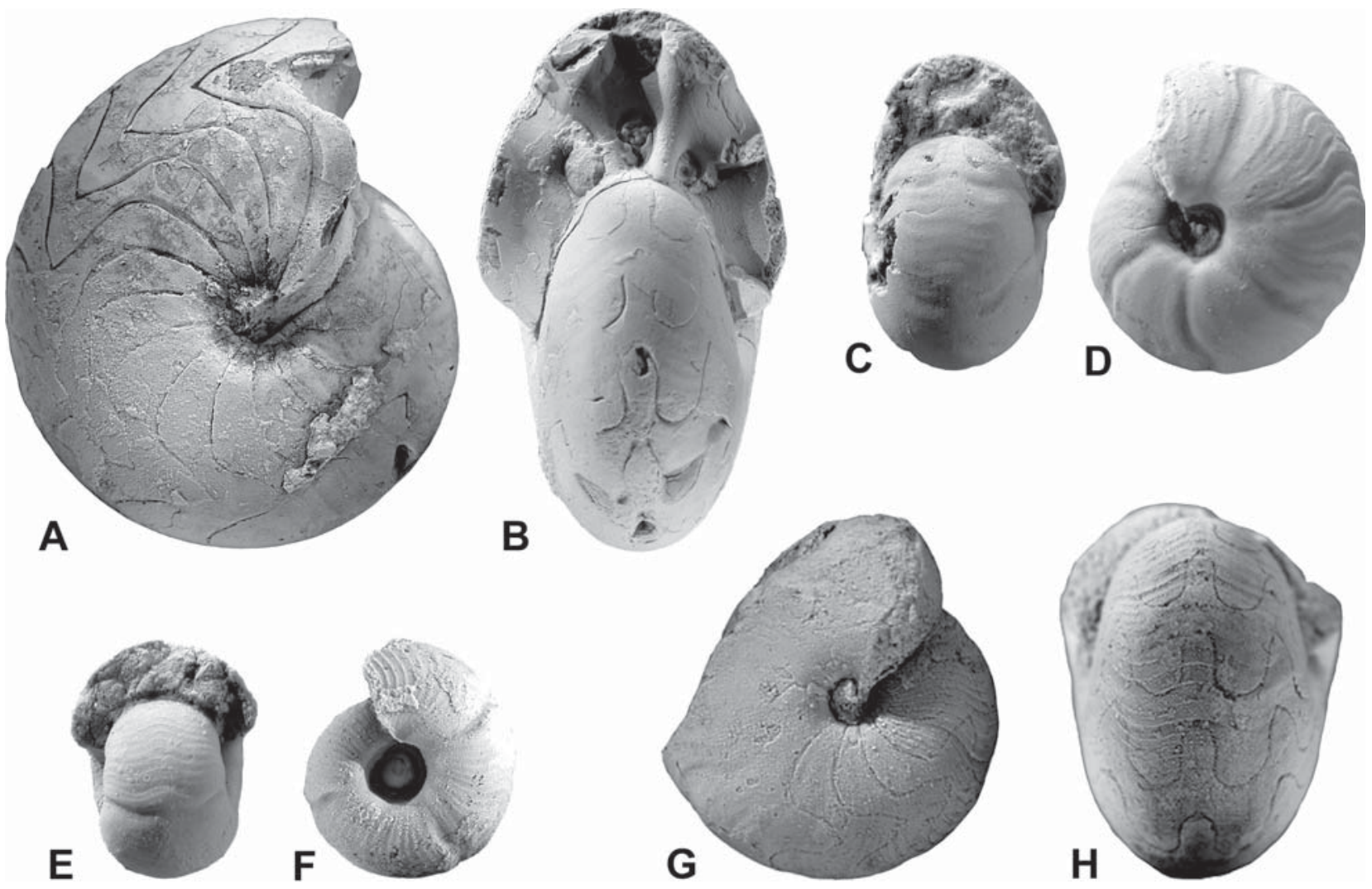

Fig. 20. Acutimitoceras occidentale n. sp. from bed 1c and bed 9 of Mfis. A, B - holotype MB.C.3810.1 from bed 1c, lateral and dorsal views, $\times 2.5$. C, D - paratype MB.C.3826.2, dorsal and lateral views, from bed $9, \times 6 . \mathbf{E}, \mathbf{F}-$ paratype MB.C.3826.3 from bed 9, dorsal and lateral views, $\times$ 8. G, H - paratype MB.C.3826.1 from bed 9, lateral and dorsal views, $\times 8$. 
which have a biconvex course. In MB.C.3826.1 (Fig. 20G, H) the distance of the growth lines is approximately $0.3 \mathrm{~mm}$. The four specimens possess weak constrictions on the last volutions, three in MB.C.3826.3 (Fig. 20E, F), six in MB.C.3826.2 (Fig. 20C, D) and five in MB.C.3826.1 (Fig. 20G, H). These constrictions are best visible on the venter and less near the umbilical edge. They follow the course of the growth lines.

The suture line of the holotype (MB.C.3810.1) at $25 \mathrm{~mm}$ diameter (Fig. 19E), possesses a narrow, tongue-shaped and slightly pouched external lobe, a broadly rounded ventrolateral saddle and a rather wide, V-shaped adventive lobe with slightly curved flanks. The adventive lobe is twice as wide as the external lobe. Ventro-lateral and dorsolateral saddles have the same height. The suture line of the smaller specimen MB.C.3810.5 has a lanceolate external lobe that is deeper than the adventive lobe.

Discussion. A species with a similar conch morphology and ornament is $A$. undulatum (Vöhringer, 1960). This species possesses fine biconvex growth lines, but the riblets present in the new species cannot be seen on the steinkern. The umbilicus shows more differences, it is funnel-shaped in $A$. occidentale but punctiform in $A$. undulatum. The suture line of the new species has a very narrow, slightly pouched external lobe that is much wider in A. undulatum.

\section{Acutimitoceras sp. 1}

Fig. 21A, B

Material. One well-preserved specimen of $48 \mathrm{~mm}$ conch diameter from bed 2 .

Discussion. The specimen MB.C.3816 (Fig. $21 \mathrm{~A}, \mathrm{~B})$ cannot be attributed to any of the known species of Acutimitoceras. The completely smooth, pachyconic conch possesses no constrictions, the umbilicus is closed. Growth lines and suture lines are not visible. Because of the lack of constrictions, a position within Mimimitoceras is unlikely.

\section{Acutimitoceras sp. 2}

Figs $21 \mathrm{C}, \mathrm{D}, 22$

Material. Four very well-preserved specimens from 12,7 to 15,3 mm diameter from bed $1 \mathrm{c}$.

Description. Two sections allow the study of the ontogeny. The conch shape is discoidal in MB.C.3808.2 (Fig. 22B) at 2,8 mm diameter (ww/ $\mathrm{dm}=0.57)$, later in ontogeny it becomes pachyconic $(\mathrm{ww} / \mathrm{dm}=0.75$ at $\mathrm{dm}=12.7 \mathrm{~mm})$. The conches are evolute up to the fifth whorl (uw/dm $=0.40$ at $\mathrm{dm}=3 \mathrm{~mm}$ ), becoming involute thereafter. MB.C.3808.3 (Fig. 22A) is a more slender specimen with a ww/dm ratio of 0.68 at $12.8 \mathrm{~mm}$ diameter. The whorl expansion rate increases continuously during ontogeny from 1.65 to 1.80 . MB.C.3808.4 (Fig. 21C, D) has equidistant, lamellous impressions of growth lines with biconvex course and a weak constriction on the venter.

The suture line of MB.C.3808.1 (Fig. 22C) has a linguiform external lobe with parallel flanks. The ventrolateral saddle is symmetrically rounded and 1.5 times as wide as the external lobe. The adventive lobe is one third shorter than the external lobe.

Discussion. $A$. sp. 2 has a conch shape that is similar to A. intermedium. The suture line, however, differs from the latter in the short adventive lobe. In this respect, it is closer to $A$. occidentale n. sp. which has a much more slender conch.
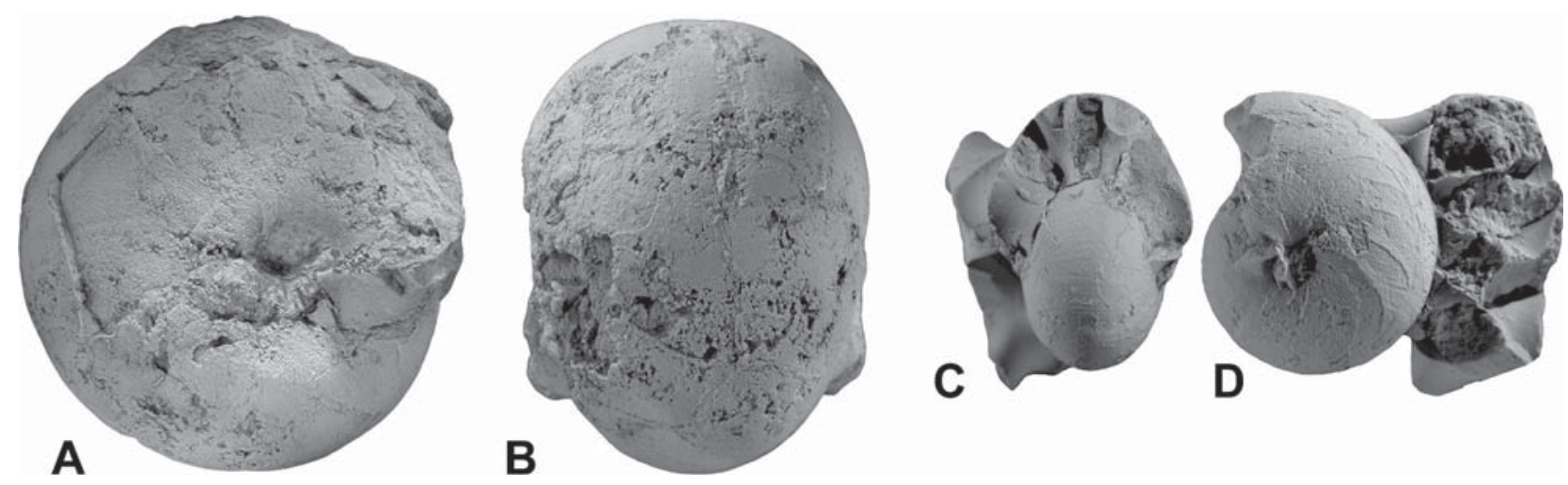

Fig. 21. Species of Acutimitoceras from bed 1c and bed 9 of Mfis. A, B - Acutimitoceras sp. 1 MB.C.3816 from bed 2, lateral and ventral views, $\times 1$. C, D - Acutimitoceras sp. 2, MB.C.3808.4 from bed 1c, dorsal and lateral views, $\times 2$. 

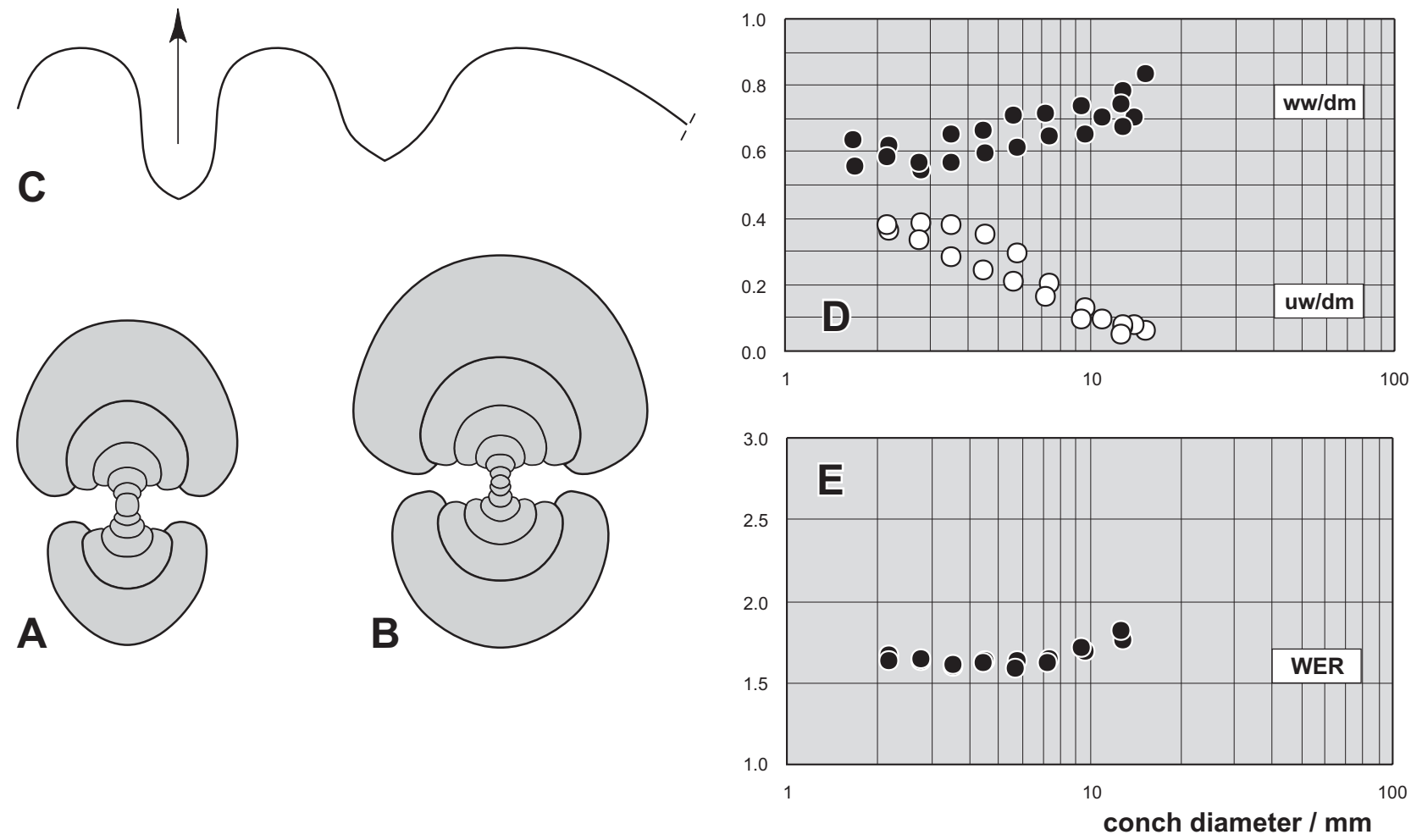

Fig. 22. Cross sections (A, B), suture line (C) and bivariate plots (D, E) of Acutimitoceras sp. 2 from bed 1c of Mfis. A MB.C.3808.3 $\times$ 3. B - MB.C.3808.2, $\times 3$. C - MB.C.3808.1 at dm $=10 \mathrm{~mm}$, ww $=7.3 \mathrm{~mm}, \times 3.5$. D - Ontogenetic development of the whorl width index $(w w / d m)$ and umbilical width index $(u w / d m)$. E - Ontogenetic development of the whorl expansion rate (WER).
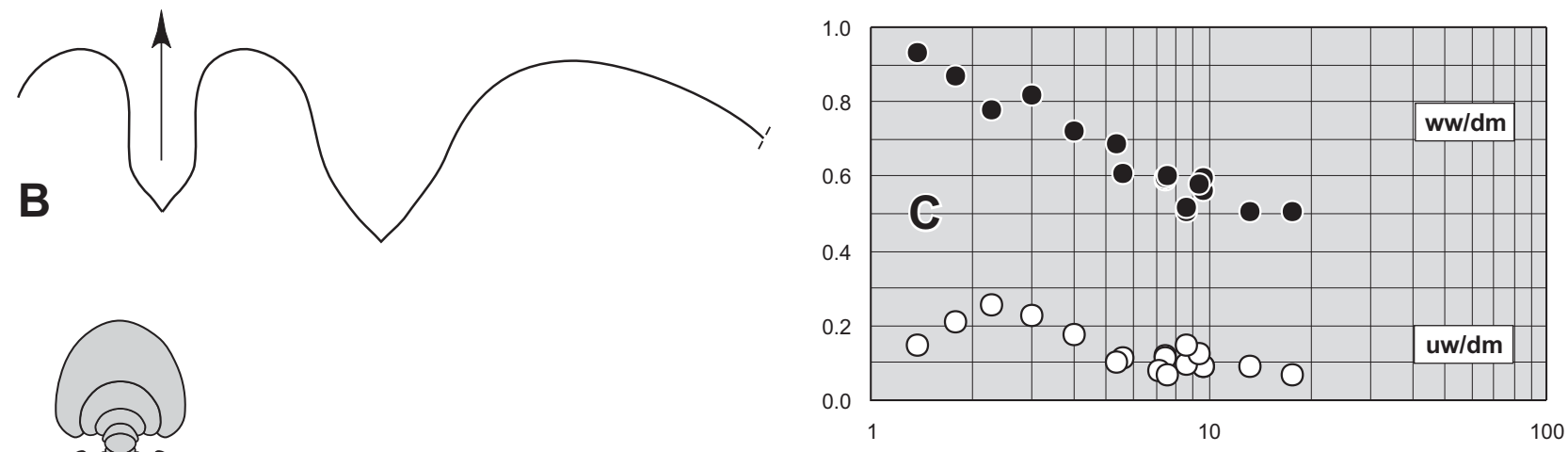

A
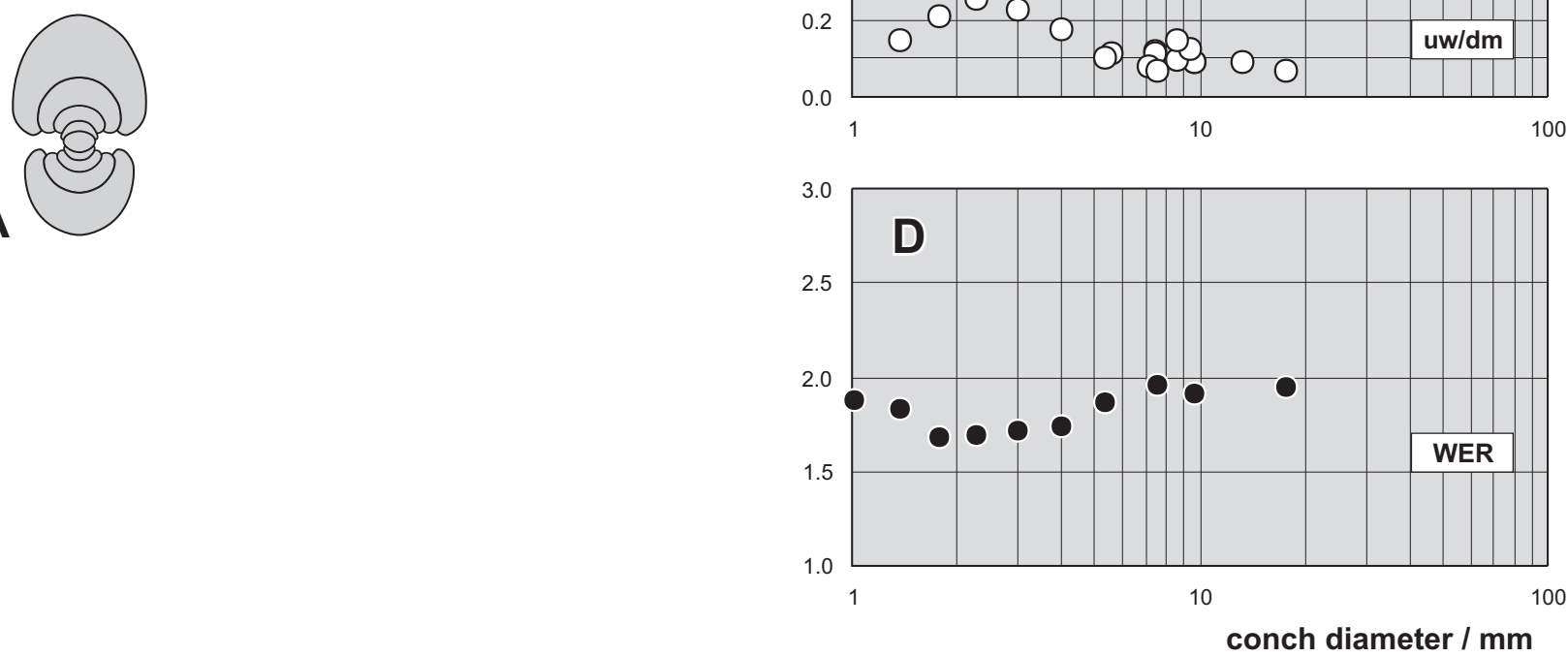

Fig. 23. Cross section (A), suture line (B) and bivariate plots (C, D) of Nicimitoceras trochiforme (Vöhringer, 1960) from bed 9 of Mfis. A - MB.C.3830.4, $\times 3$. B - MB.C.3830.2 at dm $=13.7 \mathrm{~mm}, \mathrm{ww}=7.7 \mathrm{~mm}, \times 6 . \mathbf{C}-$ Ontogenetic development of the whorl width index $(\mathrm{ww} / \mathrm{dm})$ and umbilical width index (uw/dm). D - Ontogenetic development of the whorl expansion rate (WER). 


\section{Nicimitoceras Korn, 1993}

Type species. Imitoceras subacre Vöhringer, 1960

\section{Nicimitoceras trochiforme Vöhringer, 1960}

Figs 23, 24A, B, E, F

* 1960 Imitoceras trochiforme Vöhringer: 119, pl. 1: fig. 4.

1994 Nicimitoceras trochiforme. - Korn: 59, figs 58A, 59A, B.

Holotype. Specimen IGT 1130/1 (coll. Vöhringer).

Type locality and horizon. Railway cut near Ober-Rödinghausen (Rhenish Mountains, Germany); bed 3c (Gattendorfia Stufe, Pseudarietites westfalicus Zone).

Material. One phragmocone of $18 \mathrm{~mm}$ diameter, one specimen with body chamber $(\mathrm{dm}=10 \mathrm{~mm})$ and three sectioned specimens with 10 to $12 \mathrm{~mm}$ diameter. All were collected from bed 9 and are well-preserved.

Description. Cross section MB.C.3830.4 (Fig. 23A) has, at $7 \mathrm{~mm}$ conch diameter, a thinly pachyconic shape and a very narrow umbilicus $(\mathrm{uw} / \mathrm{dm}=0.06)$. Already at this stage, it has a rather high aperture with a whorl expansion rate of 1.95 .
MB.C.3830.2 (Fig. 24A, B) is the best preserved specimen, of almost $18 \mathrm{~mm}$ conch diameter, thickly discoidal $(w w / d m=0.50)$ with an almost closed umbilicus. The umbilicus is funnelshaped with a rounded edge where the conch is widest. The surface of the steinkern is almost completely smooth and only one short constriction, limited to the venter, can be seen. The specimen is a phragmocone with 12 septa. It has a suture line drawn at a diameter of $13.7 \mathrm{~mm}$, with a lanceolate external lobe that has 0.8 of the depth of the much wider, symmetric adventive lobe. The ventrolateral saddle is broadly rounded (Fig. 23B).

The smaller specimen MB.C.3830.3 (Fig. 24E, F) has, at $9.6 \mathrm{~mm}$ conch diameter, similar conch ratios. It bears several short steinkern constrictions.

Subfamily Imitoceratinae Ruzhencev, 1950
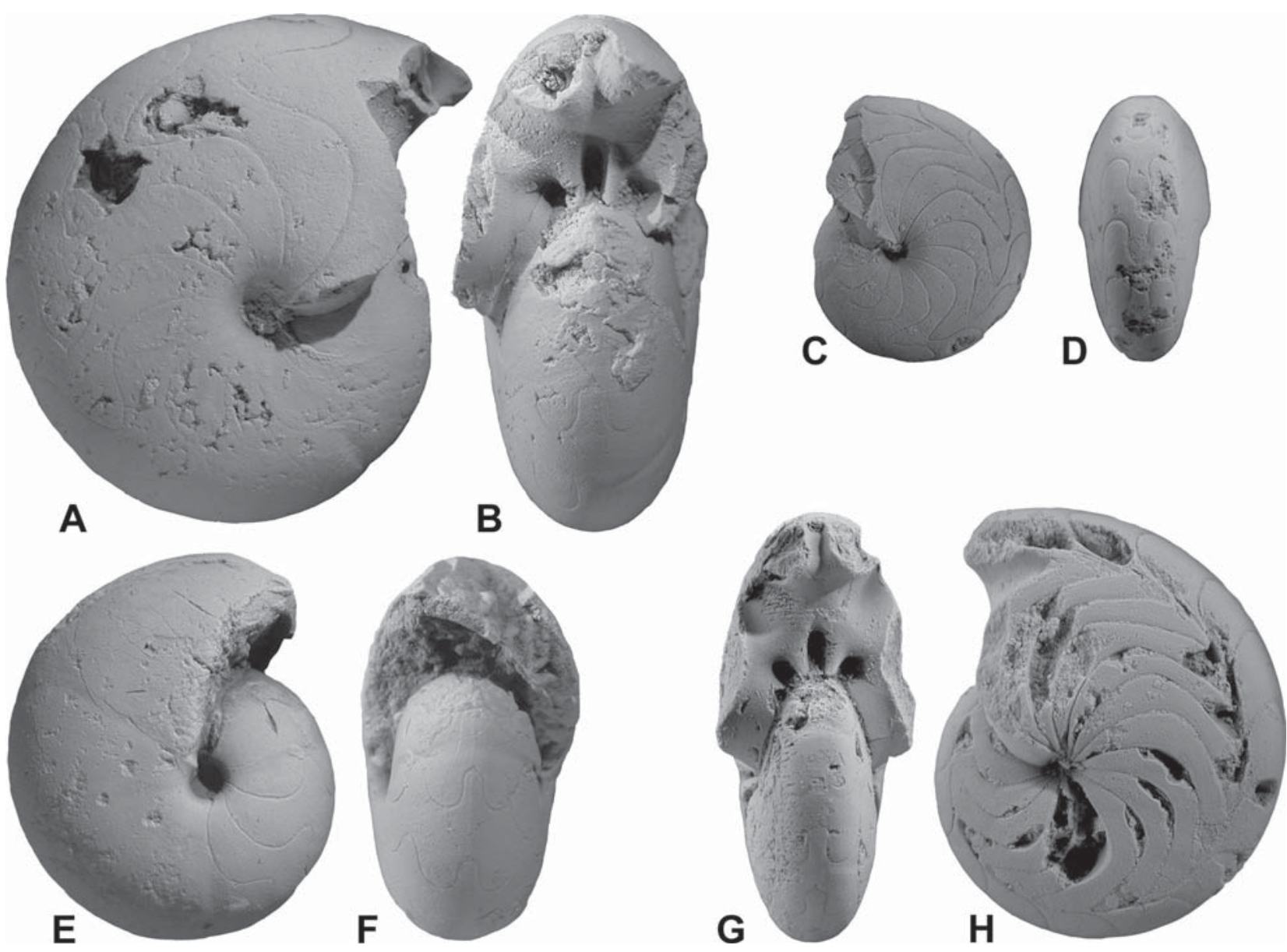

Fig. 24. Species of Nicimitoceras and Imitoceras from bed 9 of Mfis. A, B - Nicimitoceras trochiforme (Vöhringer, 1960), MB.C.3830.2, lateral and dorsal views, $\times$ 4. C, D - Imitoceras oxydentale n. sp., paratype MB.C.3831.6, lateral and ventral views, $\times$ 3. E, F - Nicimitoceras trochiforme (Vöhringer, 1960), MB.C.3830.3, lateral and dorsal views, $\times 5$. G, H - Imitoceras oxydentale n. sp., holotype MB.C.3831.1, dorsal and lateral views, $\times 3$. 


\section{Imitoceras Schindewolf, 1923}

Type species. Goniatites Ixion Hall, 1860

\section{Imitoceras oxydentale n. sp.}

Figs 24C, D, G, H, 25

Derivation of name. From the Greek $\xi_{\varsigma}=$ acute and the Latin dens $=$ tooth, after the acute, tooth-like adventive lobe.

Holotype. MB.C.3831.1; figured here in Fig. 24G, H.

Type locality and horizon. Northern slope of the Jebel Debouaâ east of Mfis (Anti-Atlas, Morocco); bed 9 (Early Tournaisian).

Material. Two small specimens from bed 7 and 11 specimens between 9 and $22 \mathrm{~mm}$ diameter from bed 9 . All are without body chambers but otherwise well-preserved.

Diagnosis. Species of Imitoceras with discoidal conch (ww/ $\mathrm{dm}=0.40-0.50)$ between 3 and $20 \mathrm{~mm}$ diameter. Inner whorls widely umbilicate ( $\mathrm{uw} / \mathrm{dm}=0.45$ at $\mathrm{dm}=2 \mathrm{~mm}$ ), umbilicus rapidly closing. Aperture moderately high, whorl expansion rate 2.10 , in stages larger than $10 \mathrm{~mm}$ diameter. Steinkern without constrictions. Suture line with small, slightly pouched external lobe and narrow adventive lobe, with a vertical ventral flank.

Description. The cross sections MB.C.3831.3 and MB.C.3831.7 (Fig. 25A and B) allow the observation of the conch ontogeny up to almost $17 \mathrm{~mm}$ diameter. Both show nearly identical on- togenies with three very evolute inner whorls and a continuous closing of the umbilicus. Between 2 and $12 \mathrm{~mm}$ diameter, there is a transition from ventrally depressed whorls (ww/wh $=1.65)$ to laterally compressed whorls (ww/wh $=0.70$ ). Furthermore, the aperture is heightened and the whorl expansion rate increases from 1.65 at $2 \mathrm{~mm}$ diameter to 2.10 at $12 \mathrm{~mm}$ diameter.

Paratype MB.C.3831.2 is with $21,7 \mathrm{~mm}$ diameter the largest specimen. It has a slender conch $(\mathrm{ww} / \mathrm{dm}=0.39)$ with a closed funnelshaped umbilicus and continuously converging flanks. It does not possess constrictions or remains of growth lines. The fully septate specimen has approximately 18 septa; the suture line of the specimen was drawn at $21 \mathrm{~mm}$ conch diameter (Fig. 25D). Some conspicuous characteristics can be seen here, the very short lanceolate external lobe, at $22 \mathrm{~mm}$ diameter and $9 \mathrm{~mm}$ whorl width, only half as deep as the adventive lobe, the wide asymmetric ventrolateral saddle, and the deep, asymmetrically V-shaped adventive lobe with a vertical ventral flank and an almost linear, inclined dorsal flank.

In the smaller specimen MB.C.3831.5 (Fig. 25C) with $12 \mathrm{~mm}$ diameter and $7 \mathrm{~mm}$ whorl
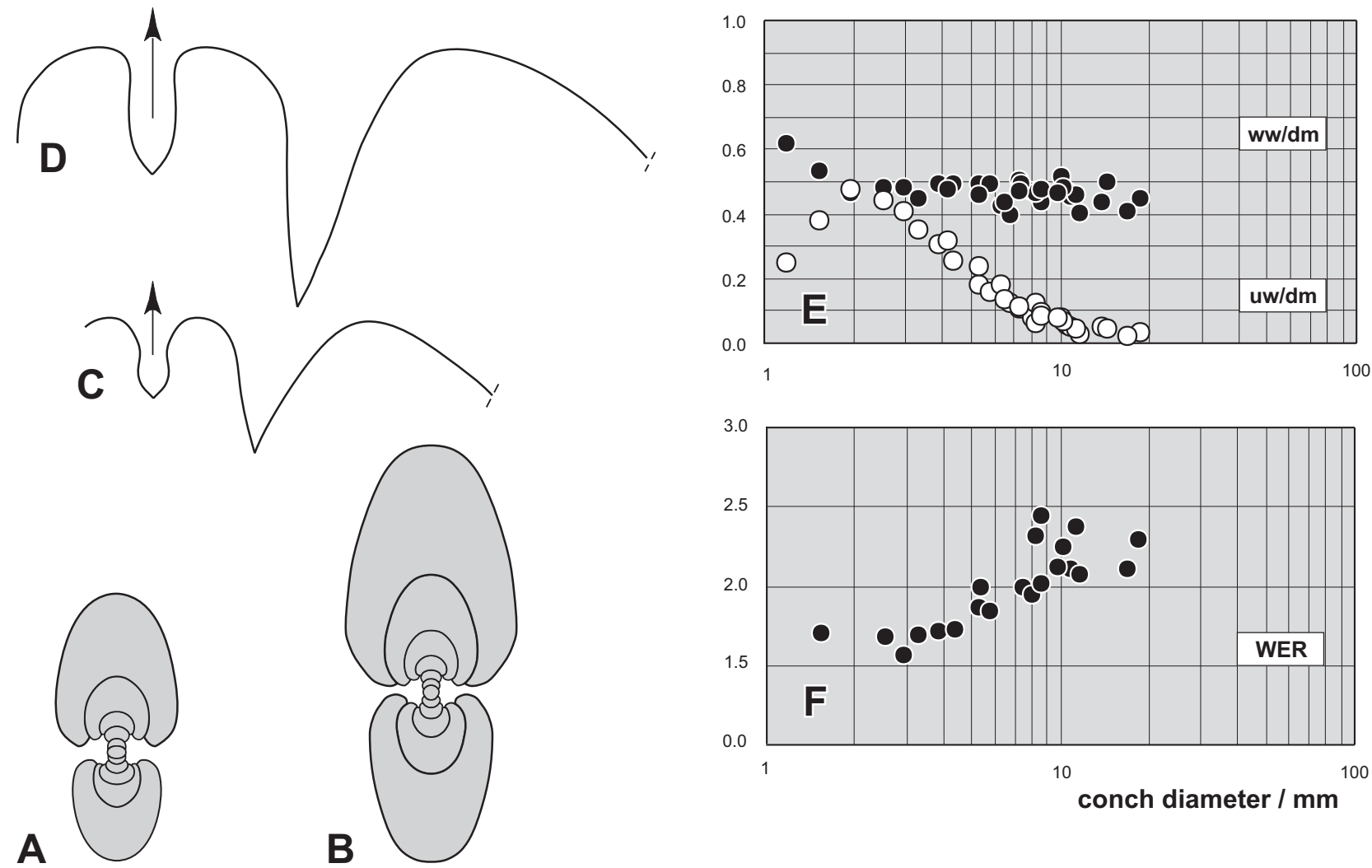

Fig. 25. Cross sections (A, B), suture lines (C, D) and bivariate plots (E, F) of Imitoceras oxydentale n. sp. from bed 9 of Mfis. A - paratype MB.C.3831.3 $\times 3$. B - paratype MB.C.3831.7, $\times 3 . \mathbf{C}-$ paratype MB.C. 3831.5 at $\mathrm{dm}=12.4 \mathrm{~mm}, w \mathrm{wh}=7 \mathrm{~mm}$, $\times 4.5$. D - paratype MB.C. 3831.2 at $\mathrm{dm}=21.6 \mathrm{~mm}, \mathrm{ww}=8.5 \mathrm{~mm}, \times 4.5 . \mathbf{E}-$ Ontogenetic development of the whorl width index (ww/dm) and umbilical width index (uw/dm). F - Ontogenetic development of the whorl expansion rate (WER). 
height, the external lobe is two thirds as deep as the adventive lobe.

Discussion. A number of species were regarded as belonging to Imitoceras, but the genus was often used as a wastebasket taxon. A revision of the group is needed; most probably, some of the species belong to other genera. The new species differs from the rather well-known, probably synonymous species I. rotatorium (de Koninck, 1844) and I. ixion (Hall, 1860) in the much more widely umbilicate inner whorls and the less pouched external lobe.

Family Gattendorfiidae Bartzsch \& Weyer, 1987 Subfamily Gattendorfiinae Bartzsch \& Weyer, 1987
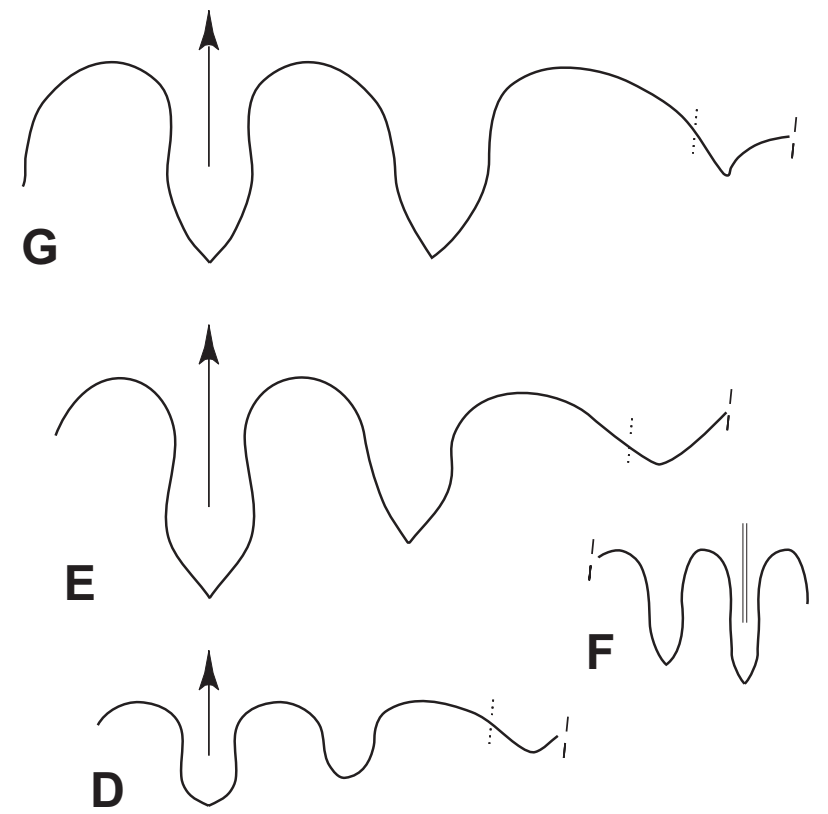

\section{Gattendorfia Schindewolf, 1920}

Type species. Goniatites subinvolutus Münster, 1832

\section{Gattendorfia crassa Schmidt, 1924}

Figs 26, 27G-J

* 1924 Gattendorfia crassa Schmidt: 151, pl. 8: figs 9-11.

1925 Gattendorfia crassa. - Schmidt: 535, pl. 19: fig. 9.

n 1952 Gattendorfia crassa. - Schindewolf: 296, pl. 2: fig. 5.

1960 Gattendorfia crassa. - Vöhringer: 154, pl. 4: figs 1-4, pl. 5: fig. 8.

1965 Gattendorfia crassa. - Weyer: 447, pl. 7: fig. 1.

1975 Gattendorfia crassa. - Popov: 115, pl. 36: fig. 9, pl. 46: fig. 8.

1982 Gattendorfia crassa. - Barzsch \& Weyer: 21, fig 6.

1986 Gattendorfia crassa. - Bartzsch \& Weyer: pl. 2: fig. 3.
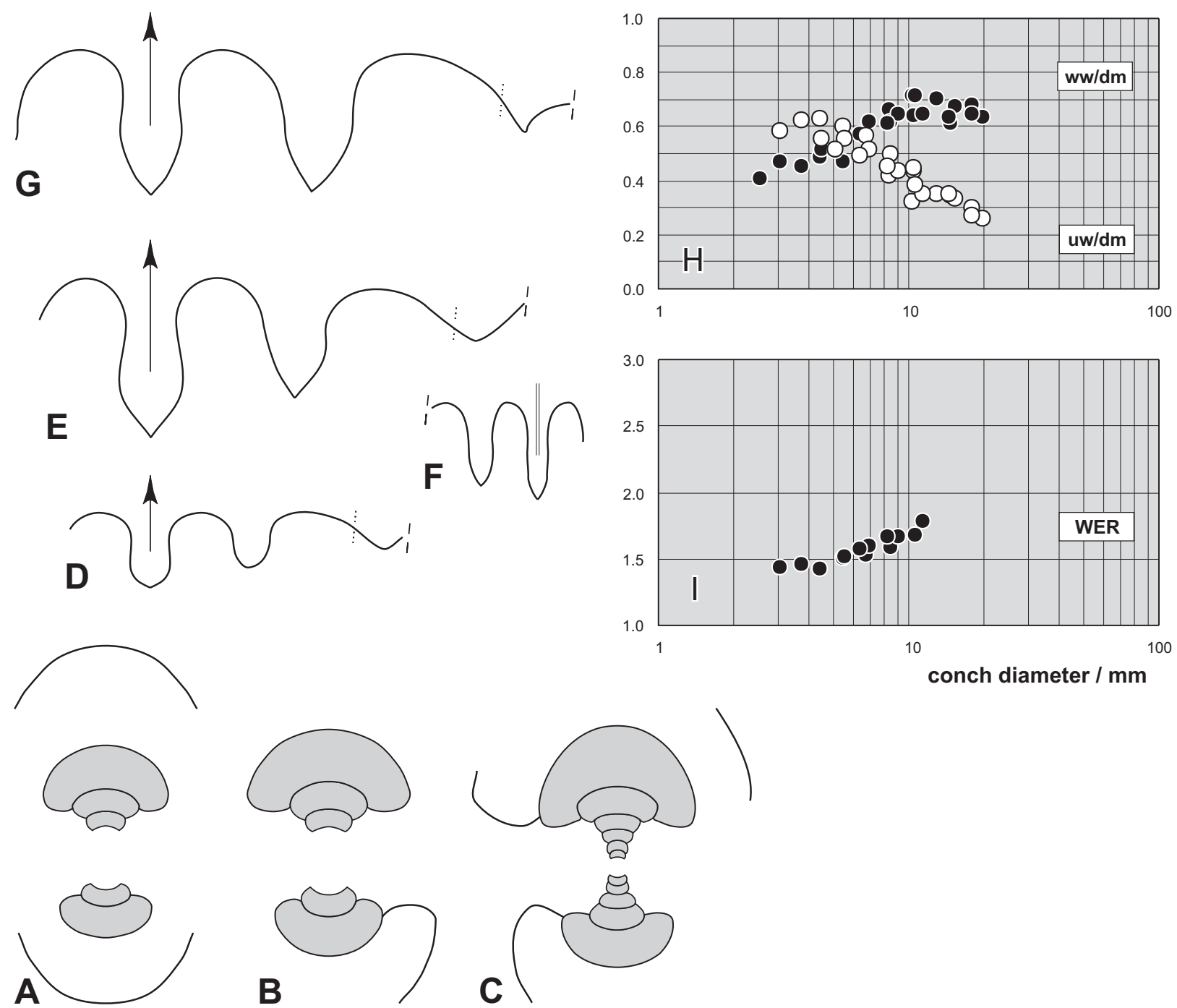

Fig. 26. Cross sections $(A-C)$, suture lines $(D-G)$ and bivariate plots (H, I) of Gattendorfia crassa Schmidt, 1924 from bed 7 and 9 of Mfis. A - MB.C.3832.4 from bed 9, $\times 3$. B - MB.C.3832.5 from bed 9, $\times$ 3. C - MB.C.3832.8 from bed 9, $\times$ 3. D - MB.C.3832.1 from bed 9, at $\mathrm{dm}=8.2 \mathrm{~mm}, \mathrm{ww}=5.2 \mathrm{~mm}, \times 6.5 . \mathbf{E}, \mathbf{F}-$ MB.C.3819 from bed 7 , at $\mathrm{ww}=6.7 \mathrm{~mm}(\mathrm{E}$ A L) and $w w=2.8 \mathrm{~mm}(\mathrm{U} \mathrm{I}), \times 6.5$. G - MB.C.3832.3 from bed 9, at $\mathrm{dm}=15 \mathrm{~mm}$, ww $=9.3 \mathrm{~mm}, \times 6.5$. H Ontogenetic development of the whorl width index (ww/dm) and umbilical width index (uw/dm). I - Ontogenetic development of the whorl expansion rate (WER). 
1994 Gattendorfia crassa. - Korn: 73, figs 66B, C, 67B, $68 \mathrm{~A}, 69 \mathrm{~A}-\mathrm{D}$.

1997 Gattendorfia crassa. - Dzik: 107, fig. 28G.

Holotype. Specimen BGRB X5714 (coll. Schmidt 1920).

Type locality and horizon. Railway cut near Ober-Rödinghausen (Rhenish Mountains, Germany); Gattendorfia Stufe.

Material. Eight phragmocones from 7 to $15 \mathrm{~mm}$ conch diameter from bed 9 and one fragment from bed 7.

Description. The cross sections MB.C.3832.4, MB.C.3832.5, and MB.C.3832.8 are incomplete, but allow the study of the conch ontogeny up to a diameter of $10.5 \mathrm{~mm}$ (Fig. 26A-C). The conch is serpenticonic within the first five whorls (approximately $8 \mathrm{~mm}$ diameter), extremely evolute (uw/dm sometimes $>0.60$ ) and possesses a low aperture with trapezoidal outline. Here, a dramatic transformation in the conch geometry takes place, with more compressed whorls with higher aperture and stagnation in the uw/ww ratio. There is some variability in speciemens of moderate size and in MB.C.3832.8 (Fig. 26C) the umbilicus is bordered by a subangular edge.
Specimen MB.C.3832.2 (leg. Becker; Fig. 27G, $\mathrm{H})$ has four weak constrictions on the last volution, extending rectiradiate across the flanks turning back to a shallow external sinus. Other specimens such as MB.C.3832.1 possess only three constrictions.

Specimen MB.C.3832.3 (Fig. 26G) shows the suture line at $15 \mathrm{~mm}$ conch diameter. The external sinus is lanceolate and pointed at its base; the ventrolateral saddle is 1.5 times as wide as the external lobe and the adventive lobe is rather wide and as deep as the external lobe. In specimen MB.C.3819 (Fig. 26E) it is slightly shorter than the external lobe.

Discussion. All specimens from Mfis are much smaller than those from the type locality; therefore, there is some uncertainty in the attribution to $G$. crassa. A comparison with the morphometric analysis by Korn \& Vöhringer (2004) shows that in the North African specimens, the ontogenetic transition from the initial serpenticonic stage to the more involute stage takes place
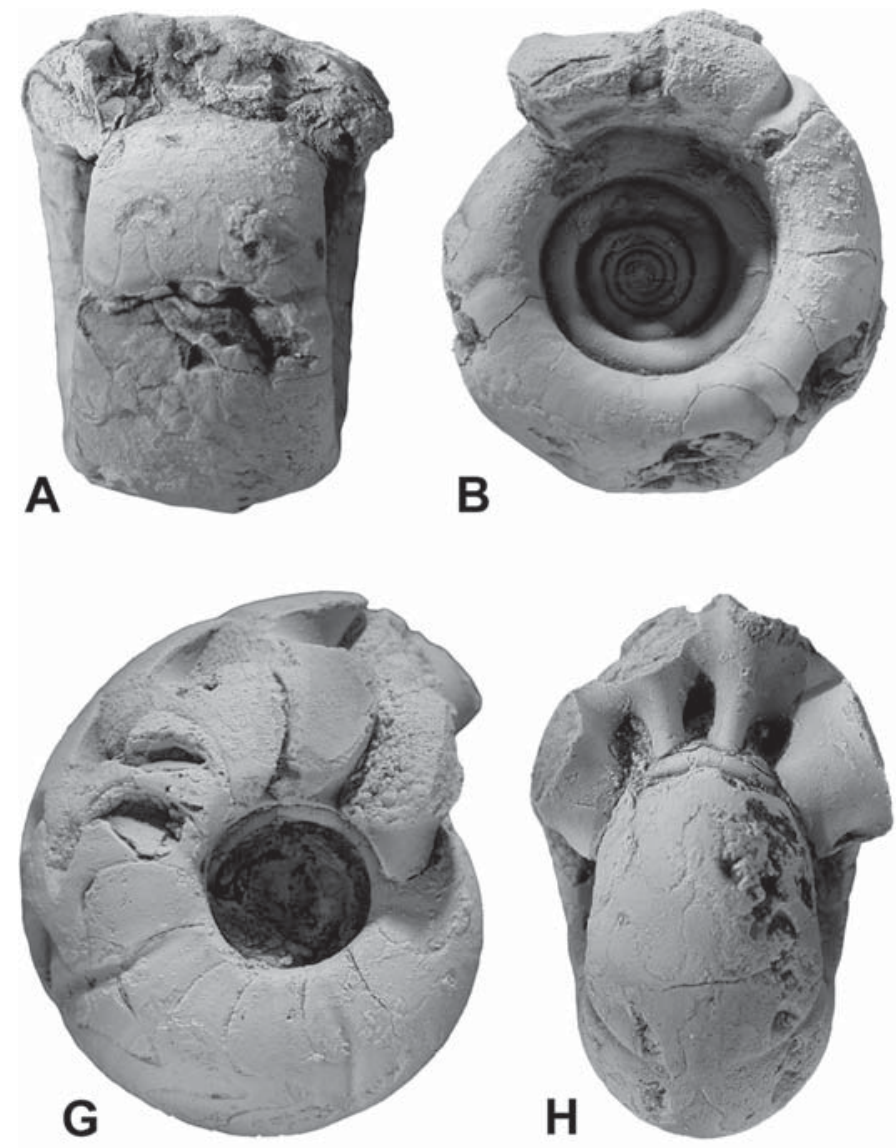

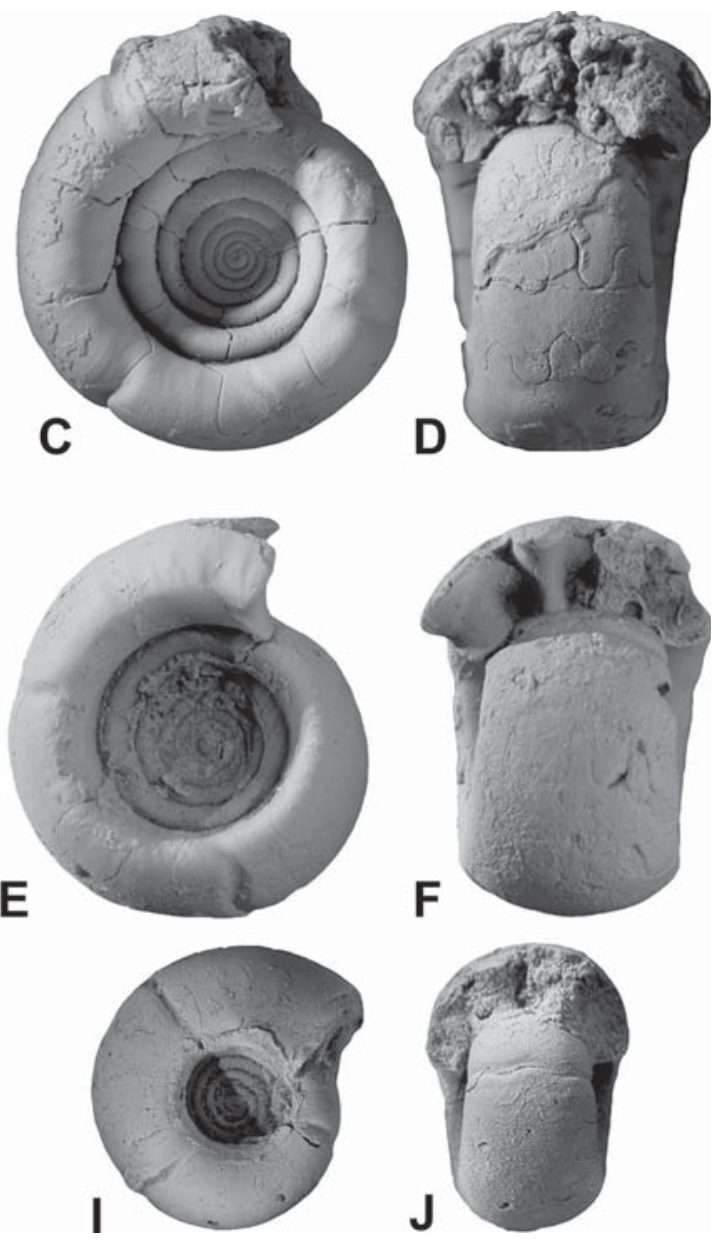

Fig. 27. Species of Gattendorfia from bed 9 of Mfis. A, B - Gattendorfia jacquelinae Ebbighausen et al., 2004, MB.C.3833.1, dorsal and lateral views, $\times$ 3. C, D - Gattendorfia jacquelinae Ebbighausen et al., 2004, MB.C.3833.2, lateral and dorsal views, $\times$ 3. E, F - Gattendorfia jacquelinae Ebbighausen et al., 2004, MB.C.3833.3, lateral and dorsal views, $\times 3$. G, H Gattendorfia crassa Schmidt, 1924, MB.C.3832.2, lateral and dorsal views (leg. Becker), $\times 3$. I, J - Gattendorfia crassa Schmidt, 1924, MB.C.3832.1, lateral and dorsal views, $\times 3$. 
one whorl earlier, at a smaller conch diameter. However, this is due to dwarfism of the specimens from Mfis, and does not indicate another species.

Gattendorfia jacquelinae Ebbighausen, Bockwinkel, Korn \& Weyer, 2004

Figs $27 \mathrm{~A}-\mathrm{F}, 28$

* 2004 Gattendorfia jacquelinae Ebbighausen et al.: 142, figs $11-13$.

Holotype. MB.C.5462.1 (coll. Ebbighausen et al. 2004).

Type locality and horizon. Dry plain immediately north-east of the Gara el Kahla, $35 \mathrm{~km}$ south-west of Timimoun, Gourara, Algeria; claystone horizon in the Grès supérieurs de Kahla, probably Early Tournaisian.

Material. 68 steinkern specimens from 3.5 to $14 \mathrm{~mm}$ conch diameter from bed 9 and 28 steinkern specimens from bed 7 .
Description. A number of specimens were sectioned, the best three of these (MB.C.3833.4-MB.C.3833.6) are figured in Fig. 28A, B, and C. All show principally the same ontogenetic trajectories of the conch geometry, e.g., the widely umbilicate inner five whorls embrace the preceding only slightly, followed by the slow transformation into strongly depressed whorls. Specimen MB.C.3833.4 and MB.C.3833.5 reach a maximum diameter of almost $13 \mathrm{~mm}$; the conches are thinly pachyconic in this stage (ww/ $\mathrm{dm}=0.70)$ and still rather widely umbilicate $(\mathrm{uw} / \mathrm{dm}=0.46)$. There are, however, also some characteristics in which the two specimens differ and therefore represent two different morphs within the species. Specimen MB.C.3833.4 (Fig. 28A) possesses a rounded umbilical edge
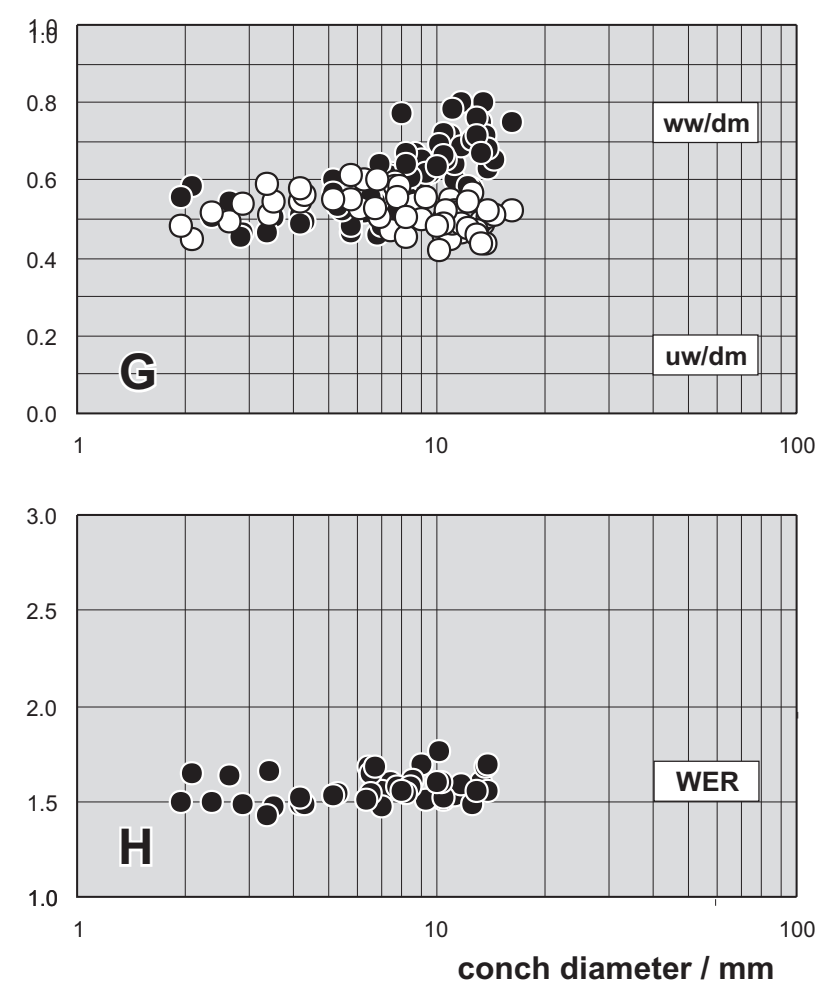
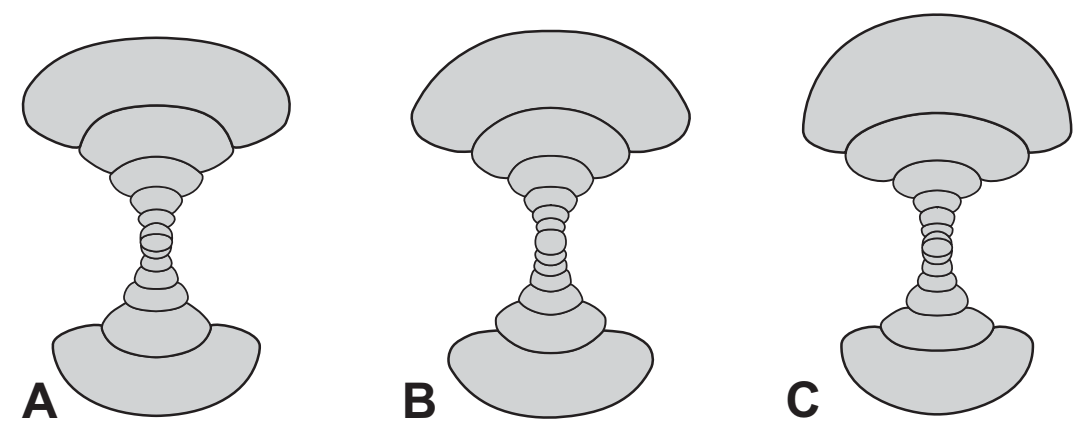

Fig. 28. Cross sections $(A-C)$, suture lines $(\mathrm{D}-\mathrm{F})$ and bivariate plots $(\mathrm{G}, \mathrm{H})$ of Gattendorfia jacquelinae Ebbighausen et al., 2004 from bed 9 of Mfis. A - MB.C.3833.4, × 3. B - MB.C.3833.5, × 3. C - MB.C.3833.6, $\times 3$. D - MB.C.3833.7 at $\mathrm{dm}=11.8 \mathrm{~mm}, \mathrm{wh}=3 \mathrm{~mm}, \mathrm{ww}=6 \mathrm{~mm}, \times 8 . \mathbf{E}-$ MB.C.3833.10 at $\mathrm{dm}=14.6 \mathrm{~mm}, \mathrm{ww}=7.2 \mathrm{~mm}, \times 8 . \mathbf{F}-$ MB.C.3833.9 at $\mathrm{dm}=11.7 \mathrm{~mm}, \mathrm{wh}=3.3 \mathrm{~mm}, \mathrm{ww}=8.3 \mathrm{~mm}, \times 8 . \mathbf{G}-$ Ontogenetic development of the whorl width index $($ ww $/ \mathrm{dm})$ and umbilical width index (uw/dm). H - Ontogenetic development of the whorl expansion rate (WER). 
and a slightly flattened venter, whereas specimen MB.C.3833.5 (Fig. 28B) shows a pronounced subangular umbilical edge and has a broadly rounded venter. All specimens have a low aperture with a whorl expansion rate that ranges 1.50 to 1.70 at 3 and $15 \mathrm{~mm}$ conch diameter.

The intraspecific variability is also noticeable in the other specimens, demonstrating that the two morphs are connected by intermediate forms and are not separable. Slightly flattened venters are also visible in specimen MB.C.3833.1 (Fig. 27A, B), whereas it is rounded in MB.C.3833.6 (Fig. 28C) and MB.C.3833.3 (Fig. 27E, F). MB.C.3833.5 (Fig. 28B) and MB.C.3833.2 (Fig. 27C, D) are intermediate forms.

An ornament can not be seen in the specimens. Constrictions, however, are common, but they may be extremely weak or even missing. The well-preserved specimen MB.C.3833.2 (Fig. 27C, D) bears, in front of the rather deep constrictions, weak nodes on the umbilical edge. The three constrictions are spaced in different distances and demonstrate the variability in strength. They have a concavo-convex course with very shallow lateral sinus and deeper ventral sinus.

The suture line of specimen MB.C.3833.9 (Fig. 28F) has, at $11.7 \mathrm{~mm}$ conch diameter, a lan- ceolate external lobe and a symmetric ventrolateral saddle. The adventive lobe is V-shaped with slightly sinuous flanks and almost as deep as the external lobe. In specimen MB.C.3833.10 (Fig. 28E), it is shorter than the external lobe; the lateral lobe has a position on the umbilical wall.

Discussion. The separation of species on the basis of juvenile specimens is not possible. $G$. jacquelinae shows some similarities with $G$. costata Vöhringer, 1960, but this species has a more angular umbilical edge. Furthermore, G. jacquelinae does not show the umbilical ribs present in G. costata. G. crassa Schmidt, 1924 differs from G. jacquelinae by its much more widely umbilicate early whorls.

\section{Kazakhstania Librovich, 1940}

Type species. Gattendorfia (Kazakhstania) karagandensis Librovich, 1940

\section{Kazakhstania evoluta (Vöhringer, 1960)}

Figs 29, 30E-H

\footnotetext{
* 1960 Gattendorfia evoluta Vöhringer: 159, figs 34a, b, pl. 5: figs $4 \mathrm{a}-\mathrm{b}$.
}
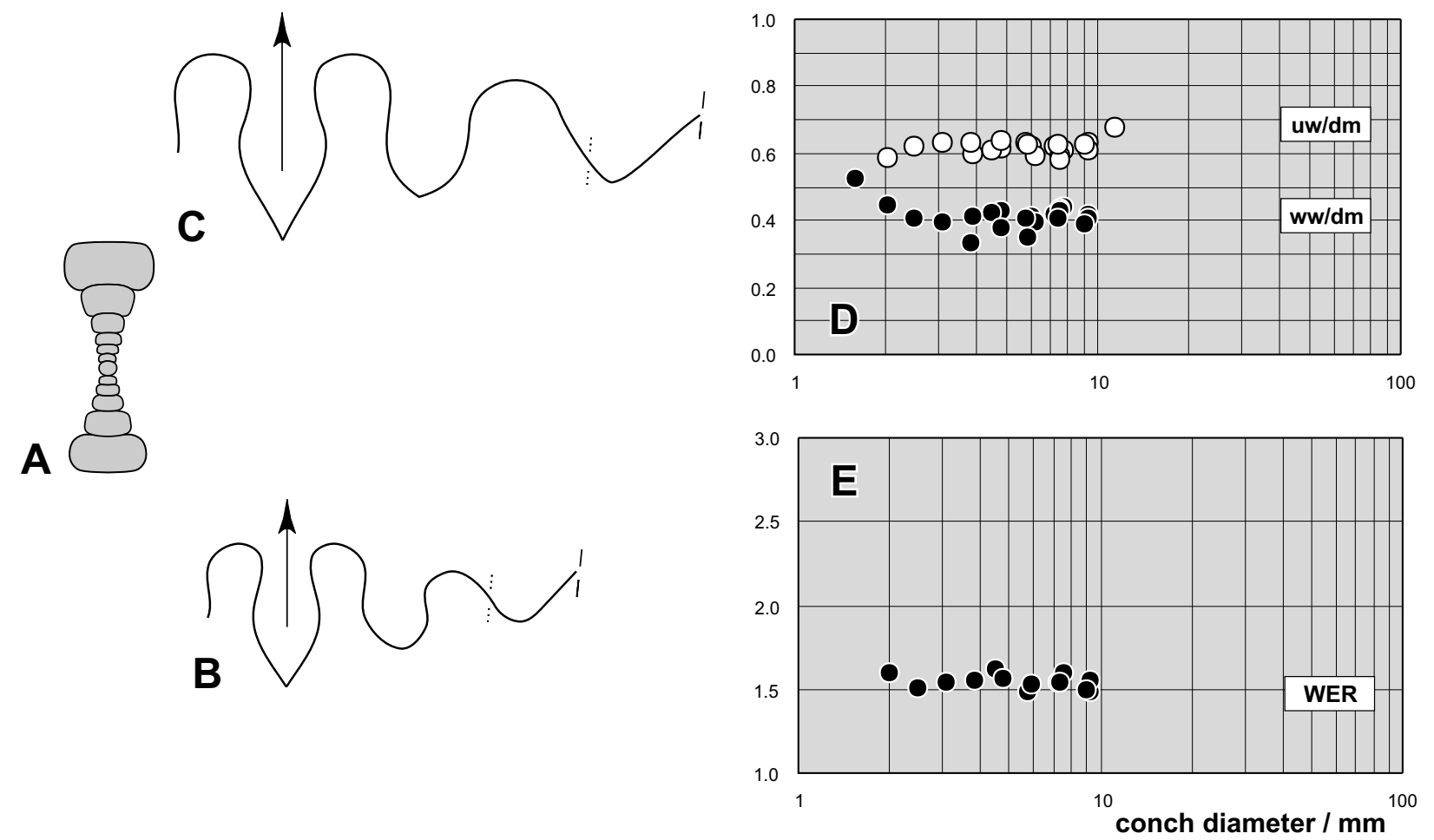

Fig. 29. Cross section (A), suture lines (B, C) and bivariate plots (D, E) of Kazakhstania evoluta (Vöhringer, 1960) from bed 7 of Mfis. A - MB.C.3820.4, $\times 3$. B - MB.C. 3820.3 at $\mathrm{dm}=6.1 \mathrm{~mm}$, wh $=1.4 \mathrm{~mm}, \times 8 . \mathbf{C}-$ MB.C. $3820.1 \mathrm{at} \mathrm{dm}=7.9 \mathrm{~mm}$, wh $=3.4 \mathrm{~mm}, \times 8 . \mathbf{D}-$ Ontogenetic development of the whorl width index (ww/dm) and umbilical width index (uw/dm). $\mathbf{E}$ - Ontogenetic development of the whorl expansion rate (WER). 
1994 Gattendorfia evoluta. - Korn: 74, figs 65I, 66L, 68F.

2003 Gattendorfia evoluta. - Korn \& Weyer: 100, pl. 2: figs 14,15 .

Holotype. Specimen IGT 1130/113 (coll. Vöhringer).

Type locality and horizon. Railway cut near Ober-Rödinghausen (Rhenish Mountains, Germany); bed 2 (Gattendorfia Stufe, Paragattendorfia patens Zone).

Material. Eight steinkern specimens of 6 to $12 \mathrm{~mm}$ conch diameter from bed 7, six of these are well-preserved.

Diagnosis. Species of Kazakhstania with discoidal conch (ww $/ \mathrm{dm}=0.38$ at $\mathrm{dm}=12 \mathrm{~mm}$ ) with strongly depressed whorls. All whorls widely umbilicate $(\mathrm{uw} / \mathrm{dm}>0.60)$. Steinkern without constrictions. Suture line with very deep, lanceolate and pouched external lobe and small, rounded adventive lobe.

Description. None of the specimens is larger than $11.5 \mathrm{~mm}$. During ontogeny no change can be seen in morphology which is worth mentioning. Cross section MB.C.3820.4 (Fig. 29A) has six whorls; all whorls have a depressed rectangular or trapezoidal cross section with flattened venter and a wide umbilicus (uw/dm $>0.60)$. The whorl expansion rate ranges between 1.50 and 1.60. The height of the aperture is almost the same as the whorl height, resulting in a very shallow imprint zone.

Specimen MB.C.3820.1 is the best preserved of the larger individuals (Fig. 30E, F). It is very evolute $(\mathrm{uw} / \mathrm{dm}=0.63)$ and thinly discoidal (ww/ $\mathrm{dm}=0.42$ ) with a completely flat venter that is bordered by an angular edge from the umbilical wall. The whorl width measures more than twice the whorl height, and the aperture is low (WER $=1.48$ ). It is a smooth phragmocone without any traceable ornament and without constrictions. The suture line of this specimen, drawn at $8 \mathrm{~mm}$ diameter, displays a lanceolate, rather strongly pouched external lobe, an asymmetric ventrolateral saddle and a rounded adventive lobe. As characteristic for the genus, the deepest suture element is the external lobe, being almost 1.5 times as deep as the adventive lobe (Fig. 29C).

Discussion. For the first time, the new material permits the study of the complete external suture line. This shows that the external lobe is much deeper than the adventive lobe and thus separates the species from typical Gattendorfia. Kazakhstania evoluta is easily distinguishable from the other species of the genus by the lack of constrictions.

\section{Kazakhstania colubrella ? (Morton, 1836)}

Figs 30C, D, 31

? 1836 Ammonites colubrellus Morton: 154, figs 49, 51.

? 1971 Kazakhstania colubrella. - Manger: 37, pl. 12: figs 8, $10-12$.
Types. Original types are probably lost. Hypotypes from the Logan Formation of Ohio were figured and described by Manger (1971).

Material. Only one well-preserved steinkern specimen with $12 \mathrm{~mm}$ conch diameter.

Description. The conch is serpenticone in the first six whorls (up to approximately $6 \mathrm{~mm}$ diameter) and has a circular whorl cross section. Thereafter, the flanks become compressed and the venter remains rounded. Whorl and aperture height increase only slightly. All growth stages are widely umbilicate, but the uw/dm ratio decreases during ontogeny. All but the last whorl embrace the preceding only slightly, the umbilical edge is always rounded. All whorls possess three rursiradiate, linear steinkern constrictions, (MB.C.3834, Fig. 30C, D).

Suture line (Fig. 31) with narrow, parallel-sided external lobe, rounded ventrolateral saddle, widely rounded adventive lobe and a similar lateral lobe. The external lobe is twice as deep as the adventive lobe and the lateral lobe.

Discussion. The single specimen from Mfis is smaller than the material figured by Manger (1971); the adventive lobe of the original $\mathrm{Ka}$ zakhstania colubrella (Morton, 1836) is V-shaped and acute in contrast to our material from Mfis. This may be due to the difference in size, because the suture line of the Mfis specimen was drawn at a diameter of $5 \mathrm{~mm}$ and that from Ohio at a diameter of $17 \mathrm{~mm}$.

\section{Kazakhstania nitida n. sp.}

Figs 30A, B, 32

Derivation of name. From the Latin nitidus = neat, because of the morphology of the species.

Holotype. MB.C.3835.1; figured here in Fig. 30A, B.

Type locality and horizon. Northern slope of the Jebel Debouaâ east of Mfis (Anti-Atlas, Morocco); bed 9 (Early Tournaisian).

Material. Five well-preserved steinkern specimens from 4 to $16 \mathrm{~mm}$ conch diameter from bed 9 .

Diagnosis. Species of Kazakhstania with thinly discoidal conch $(\mathrm{ww} / \mathrm{dm}=0.35$ at $\mathrm{dm}=5 \mathrm{~mm})$ and thickly discoidal conch at $12 \mathrm{~mm}$ diameter $(\mathrm{ww} / \mathrm{dm}=0.50)$ with strongly depressed whorls. All whorls widely umbilicate (uw/dm $>0.60$ at $\mathrm{dm}=5 \mathrm{~mm}$ and 0.55 at $\mathrm{dm}=12 \mathrm{~mm}$ ). Steinkern with strong, concavo-convex constrictions. Suture line with very deep, lanceolate and pouched external lobe and small, lanceolate adventive lobe.

Description. The cross section of paratype MB.C.3835.4 (Fig. 32A) allows the observation of the conch ontogeny up to a diameter of $12 \mathrm{~mm}$. Two morphologically different ontogenetic stages can be recognised: an early serpenticonic stage 

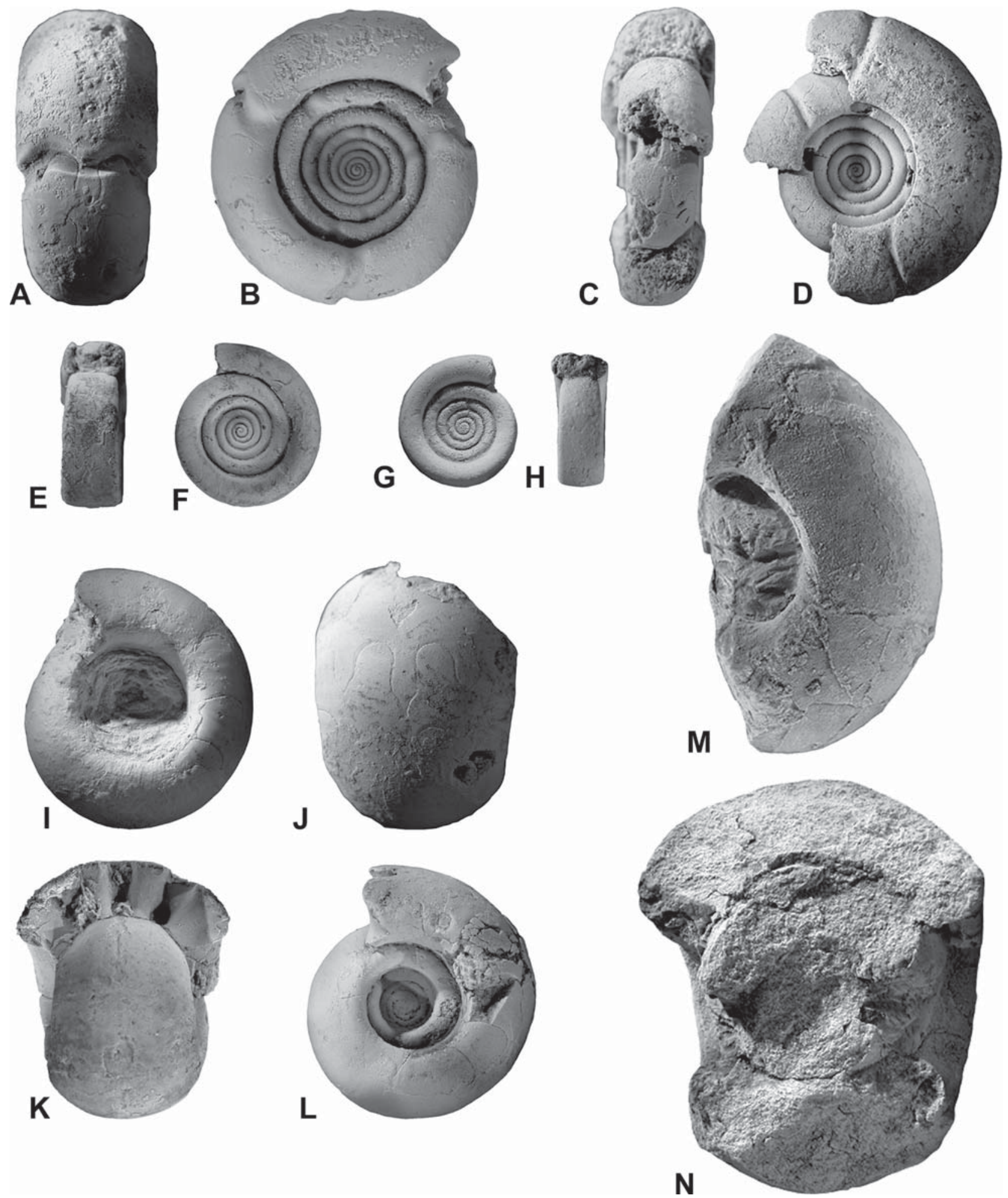

Fig. 30. Species of Kazakhstania and Zadelsdorfia from bed 2, bed 7 and bed 9 of Mfis. A, B - Kazakhstania nitida n. sp., holotype MB.C.3835.1 from bed 9, ventral and lateral views, $\times$ 3. C, D - Kazakhstania colubrella ? (Morton, 1836), MB.C.3834 from bed 9, dorsal and lateral views, $\times$ 4. E, F - Kazakhstania evoluta Vöhringer, 1960, MB.C.3820.1 from bed 7, dorsal and lateral views, $\times$ 3. G, H - Kazakhstania evoluta Vöhringer, 1960, MB.C.3820.2 from bed 7, lateral and dorsal views, $\times 3$. I, J - Zadelsdorfia debouaaensis n.sp., paratype MB.C.3836.2 from bed 9, lateral and ventral views, $\times 3 . \mathbf{K}, \mathbf{L}-$ Zadelsdorfia debouaaensis n.sp., holotype MB.C.3836.1 from bed 9, dorsal and lateral views, $\times 3$. M, N - Zadelsdorfia debouaaensis n. sp., MB.C.3815.1 from bed 2, dorsal and lateral views, $\times 2$.

with extremely wide umbilicus (uw/dm $>0.60$ ) with barely embracing whorls and a second stage, present in the last whorl, with an increase of the whorl width that leads to ventrally de- pressed whorls with a crescent-shaped cross section. The aperture is low in all stages (WER $=1.40-1.50$ ), six whorls can already be counted at a diameter of $12 \mathrm{~mm}$. 


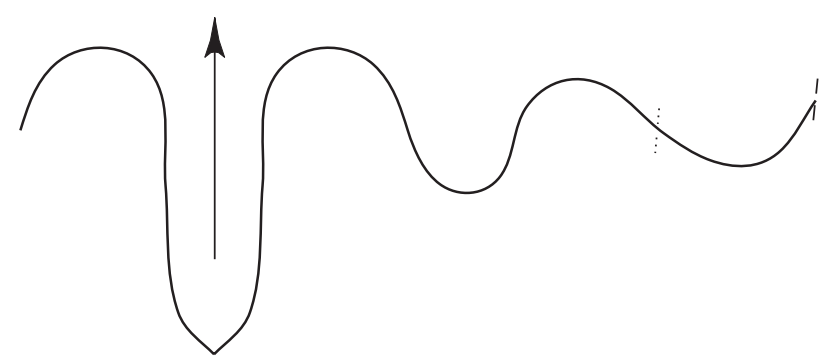

Fig. 31. Suture line of Kazakhstania colubrella ? (Morton, 1836) from bed 9 of Mfis. MB.C.3834 at ww $=2.7 \mathrm{~mm}, \times 15$.

Holotype MB.C.3835.1 (Fig. 30A, B) is a wellpreserved specimen of almost $16 \mathrm{~mm}$ conch diameter. It is discoidal $(\mathrm{ww} / \mathrm{dm}=0.45)$ with a wide umbilicus (uw/dm $=0.56$ ) and depressed whorls. The last whorl has four deep constrictions. They have a concavo-convex course, i.e., they project markedly on the umbilical wall and form a rather shallow ventral sinus. The height and width of the aperture increase markedly immediately after the constrictions. The phragmocone has about 15 septa and the suture line (drawn at $14 \mathrm{~mm}$ diameter) shows a deep, pouched external lobe with pointed base, a continuously rounded ventrolateral saddle, a lanceolate adventive lobe and an angular lateral lobe on the umbilical wall. The external lobe is more than 1.5 times deeper than the adventive lobe (Fig. 32B).
Discussion. Kazakhstania nitida differs from the other known species of the genus in its strongly depressed, very wide whorl cross section. A second criterion for separation is the form of the concavo-convex constrictions, which have a more linear course in the other known species of Kazakhstania, such as K. karagandensis (Librovich, 1940), K. depressa (Librovich, 1940), K. americana Miller \& Garner, 1955, and K. colubrella (Morton, 1836).

\section{Zadelsdorfia Weyer, 1972}

Type species. Gattendorfia asiatica Librovich, 1940

\section{Zadelsdorfia debouaaensis n. sp.}

Figs 30I-N, 33

Derivation of name. After the Jebel Debouaâ, where the specimens were collected.

Holotype. MB.C.3836.1; figured here in Fig. 30K, L.

Type locality and horizon. Northern slope of the Jebel Debouaâ east of Mfis (Anti-Atlas, Morocco); bed 9 (Early Tournaisian).

Material. Two well-preserved steinkern specimens, 14 and $18 \mathrm{~mm}$ conch diameter, from bed 9 . Three specimens from bed 2, MB.C.3815.1 (Fig. 30M, N), MB.C.3815.2 and
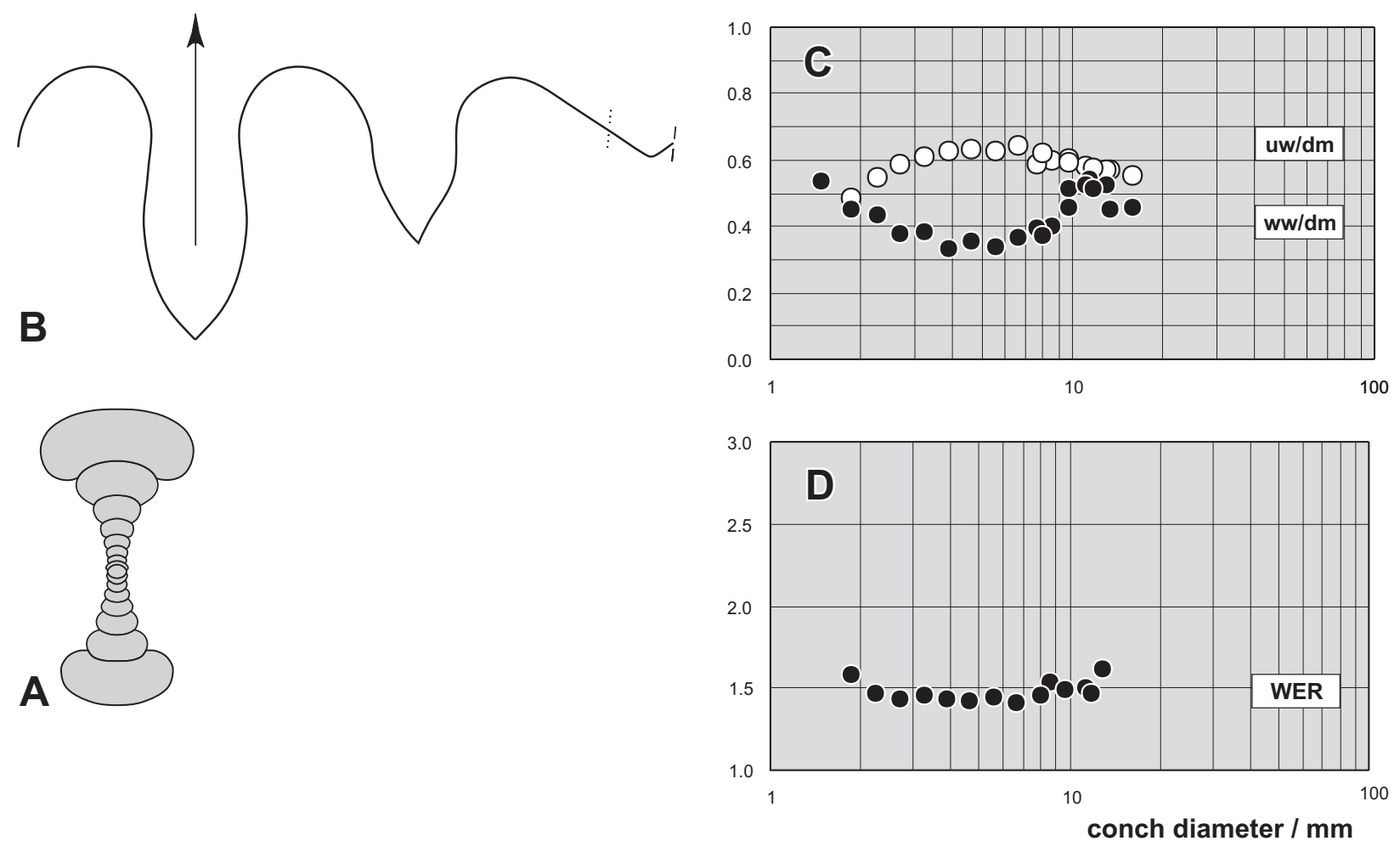

Fig. 32. Cross section (A), suture line (B) and bivariate plots (C, D) of Kazakhstania nitida n. sp. from bed 9 of Mfis. A paratype MB.C.3835.4, $\times 3$. B - holotype MB.C.3835.1 at $\mathrm{dm}=13.9 \mathrm{~mm}, \mathrm{ww}=6.2 \mathrm{~mm}, \times 10 . \mathbf{C}-$ Ontogenetic development of the whorl width index $(w w / d m)$ and umbilical width index (uw/dm). D - Ontogenetic development of the whorl expansion rate (WER). 

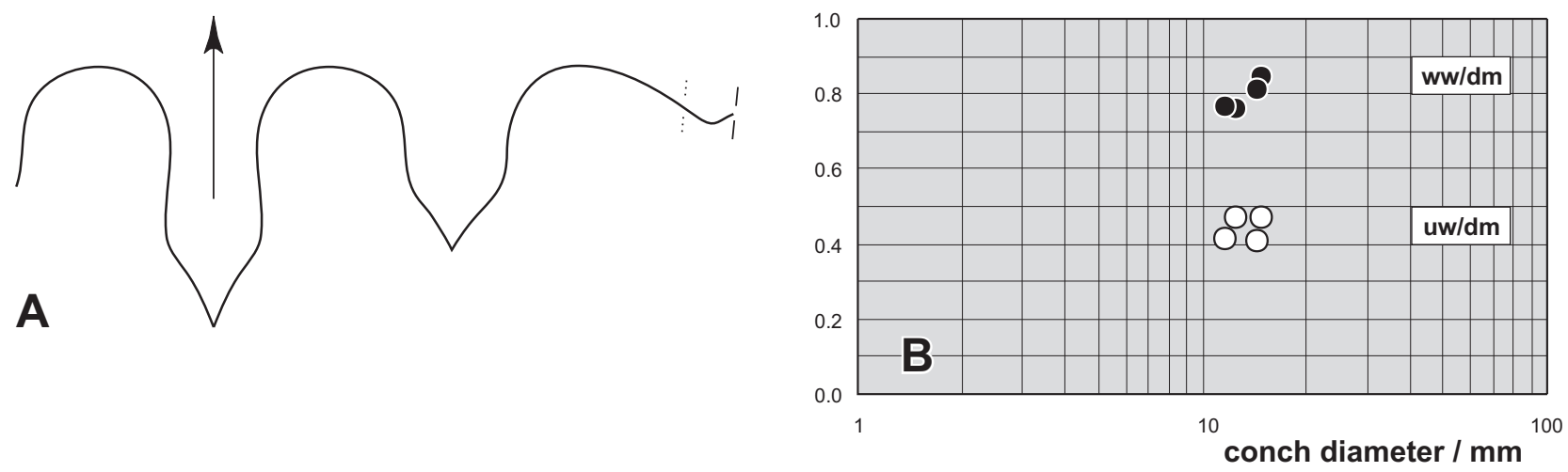

Fig. 33. Suture line (A) and bivariate plot (B) of Zadelsdorfia debouaaensis n. sp. from bed 9 of Mfis. A - paratype MB.C.3836.2 at $\mathrm{dm}=13 \mathrm{~mm}$, ww $=10 \mathrm{~mm}, \times 8 . \mathbf{B}-$ Ontogenetic development of the whorl width index $(\mathrm{ww} / \mathrm{dm})$ and umbilical width index (uw/dm).

MB.C.3815.3, probably belong to the same species, but due to bad preservation, a definite classification is not possible.

Diagnosis. Species of Zadelsdorfia with thickly pachyconic conch $(\mathrm{ww} / \mathrm{dm}=0.75-0.85$ at $\mathrm{dm}=12 \mathrm{~mm})$. Umbilicus wide (uw/dm 0.40-0.48). Steinkern lacks ornament. Suture line with very deep, lanceolate and slightly pouched external lobe and small, lanceolate adventive lobe.

Description. Holotype MB.C.3836.1 (Fig. 30K, $\mathrm{L})$ is the best preserved specimen. It has a diameter of $14 \mathrm{~mm}$, where the conch is pachyconic $(\mathrm{ww} / \mathrm{dm}=0.81)$ with a rather wide umbilicus $(\mathrm{uw} / \mathrm{dm}=0.41)$ and a very low aperture (WER =1.62). Flanks and venter are one unit and are continuously rounded; they are separated from the steep umbilical wall by a subangular edge which possesses some barely visible nodes. Otherwise, the steinkern is smooth without any traces of constrictions.

The suture line is well-visible only in the paratype MB.C.3836.2 (Fig. 33A). There is a deep, lanceolate and slightly pouched external lobe, an almost symmetric and broadly rounded ventrolateral saddle, and a lanceolate and pointed adventive lobe. The external lobe is 1.40 as deep as the adventive lobe and the dorsolateral saddle is as high as the ventrolateral saddle.

Discussion. About 12 species can be attributed to the genus Zadelsdorfia, but many of them are insufficiently described and therefore difficult to interpret. The placing of the material to $Z a$ delsdorfia is preferred for several reasons, (1) the pouched and very deep external lobe, (2) the lack of steinkern constrictions, and (3) the rectiradiate direction of the growth line impressions. A pouched external lobe, however, is also present in some of the species of Gattendorfia (Korn 1994, Fig. 67), but here, the external lobe is not deeper than the adventive lobe. The direction of the growth lines is rursiradiate in Gattendorfia; species of this genus usually possess steinkern constrictions.
The new species can not be confused with any of the other species within the assemblages from Mfis. Most of the other species of Zadelsforfia, such as Z. asiatica (Librovich, 1940), Z. subaperta (Librovich, 1940), Z. nuraensis (Librovich, 1940), Z. stummi (Miller \& Garner, 1955), and Z. yaliana (Liang, 1976) differ in their more slender conches, with a ww/dm ratio ranging between 0.40 and 0.60 .

\section{Weyerella n. gen.}

Type species. Weyerella protecta $n$. $\mathrm{sp}$

Derivation of name. In honour of Dieter Weyer (Berlin) for his continuous assistance and support.

Composition of the genus.

angularia: Gattendorfia angularia Liang \& Wang, 1991; Xingiang.

concava: Gattendorfia concava Vöhringer, 1960; Rhenish Mountains.

discoides: Gattendorfia discoides Ruan, 1981; Guizhou. mimica: Gattendorfia mimica Ruan, 1981; Guizhou.

minor: Weyerella minor n. sp.; Anti-Atlas.

molaris: Gattendorfia molaris Vöhringer, 1960; Rhenish Mountains.

parapplanata: Gattendorfia parapplanata Sheng, 1984; Xingiang.

popanoides: Gattendorfia popanoides Ruan, 1981; Guizhou. protecta: Weyerella protecta $\mathrm{n}$. sp.; Anti-Atlas.

reticulum: Gattendorfia reticulum Vöhringer, 1960; Rhenish Mountains.

Genus definition. Genus of the subfamily Gattendorfiinae with significant ontogenetic changes. Juvenile stage serpenticonic with circular whorl cross section; adult stage with compressed whorls and increasing height of the aperture. Adult overlap of the umbilicus by the inner flank.

Discussion. The possibility of a separation of the group of Gattendorfia molaris Vöhringer, 1960 from the group of Gattendorfia subinvoluta (Münster, 1832) has been discussed several times (Vöhringer 1960; Weyer 1976; Becker 1993, 1996; Becker \& Weyer 2004). Weyerella differs from typical Gattendorfia in the mode of umbili- 
cus, closing with an overlap of the whorls over the preceding and in the platyconic conch shape of the adult conch. A genus with similar morphology is Gattenpleura; but this has, in contrast to Weyerella, an ornament with bifurcate riblets. In the suture line and the conch shape, there are close similarities, probably reflecting an evolutionary lineage from Gattendorfia to Weyerella and finally Gattenpleura.

Stratigraphic and geographic distribution. Early Tournaisian; Germany (Rhenish Mountains, Thuringia), China (Guizhou, Xinjiang), and Morocco (Anti-Atlas).
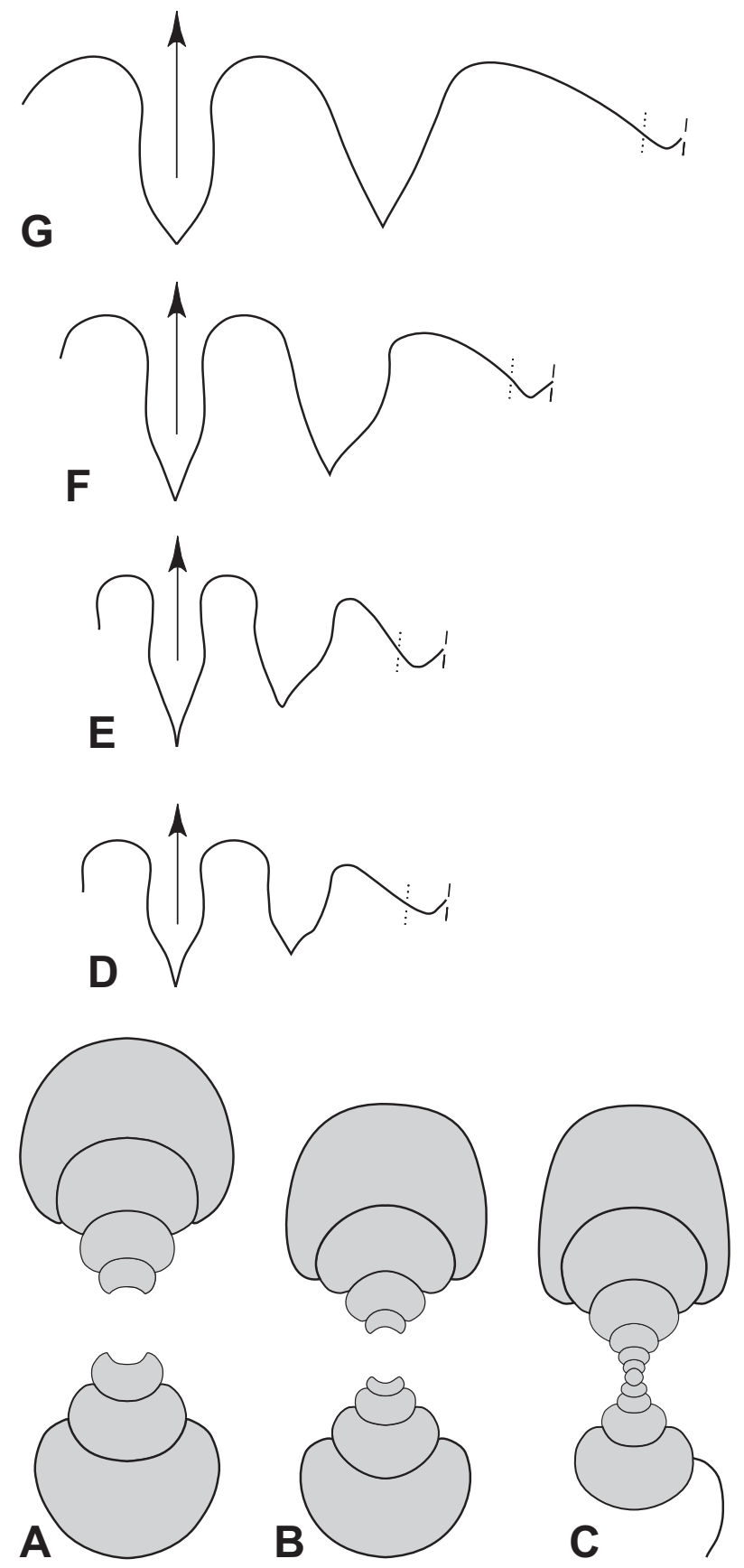

Fig. 34. Cross sections $(A-C)$, suture lines $(D-G)$ and bivariate plots $(\mathrm{H}, \mathrm{I})$ of Weyerella protecta $\mathrm{n}$. sp. from bed 9 of Mfis. A - paratype MB.C.3837.4, × 3. B - paratype MB.C.3837.3, $\times 3 . \mathbf{C}-$ paratype MB.C.3837.5, $\times 3 . \mathbf{D}-$ paratype MB.C. 3837.9 at $\mathrm{wh}=2.4 \mathrm{~mm}, \mathrm{ww}=4 \mathrm{~mm}, \times 6.5$. E - paratype MB.C. 3837.8 at $\mathrm{dm}=8.5 \mathrm{~mm}$, wh $=2.5 \mathrm{~mm}$, $\times$ 6.5. F - holotype MB.C.3837.1 at wh $=4.3 \mathrm{~mm}$, $\mathrm{ww}=6.0 \mathrm{~mm}, \quad \times 6.5 . \mathbf{G}-$ The same specimen at $\mathrm{dm}=19.7 \mathrm{~mm}, \mathrm{wh}=7.4 \mathrm{~mm}, \mathrm{ww}=7.5 \mathrm{~mm}, \times 6 . \mathbf{H}-$ Ontogenetic development of the whorl width index (ww/dm) and umbilical width index (uw/dm). I - Ontogenetic development of the whorl expansion rate (WER). 
0.40-0.50) in all stages. Whorl expansion rate decreasing during ontogeny to 1.60 at $20 \mathrm{~mm}$ diameter. Steinkern with strong concavo-convex constrictions. Suture line with very deep, lanceolate and slightly pouched external lobe and lanceolate adventive lobe. Adventive lobe much shorter than the external lobe; dorsolateral saddle strikingly asymmetric and subangular.

Description. A number of specimens were measured, and thus the ontogeny and intraspecific variability can be outlined. There is an inconspicuous ontogenetic trend towards a more slender conch; small individuals of $5 \mathrm{~mm}$ diameter have a thickly discoidal conch (ww/dm $=0.50-0.55$ ), which is transformed in larger specimens to a thinly discoidal conch at $15-20 \mathrm{~mm}$ diameter $(\mathrm{ww} / \mathrm{dm}=0.40-0.45)$. During this growth interval no significant change in the umbilical width can be observed; the uw/dm ratio is rather stable with a value of $0.40-0.50$. In contrast to most other ammonoid species of the genus, there is an ontogenetic decrease in the height of the aperture, with a reduction of the whorl expansion rate from 1.80 at $5 \mathrm{~mm}$ conch diameter to $1.50-1.60$ at $20 \mathrm{~mm}$ diameter (Fig. 34I).

Some specimens were sectioned; three of these are figured here (Fig. 34A-C). They display some variability in conch shape, particularly when the adult whorls are examined. MB.C.3837.4 (Fig. 34A) shows minor ontogenetic changes; only the embracing of the last volution
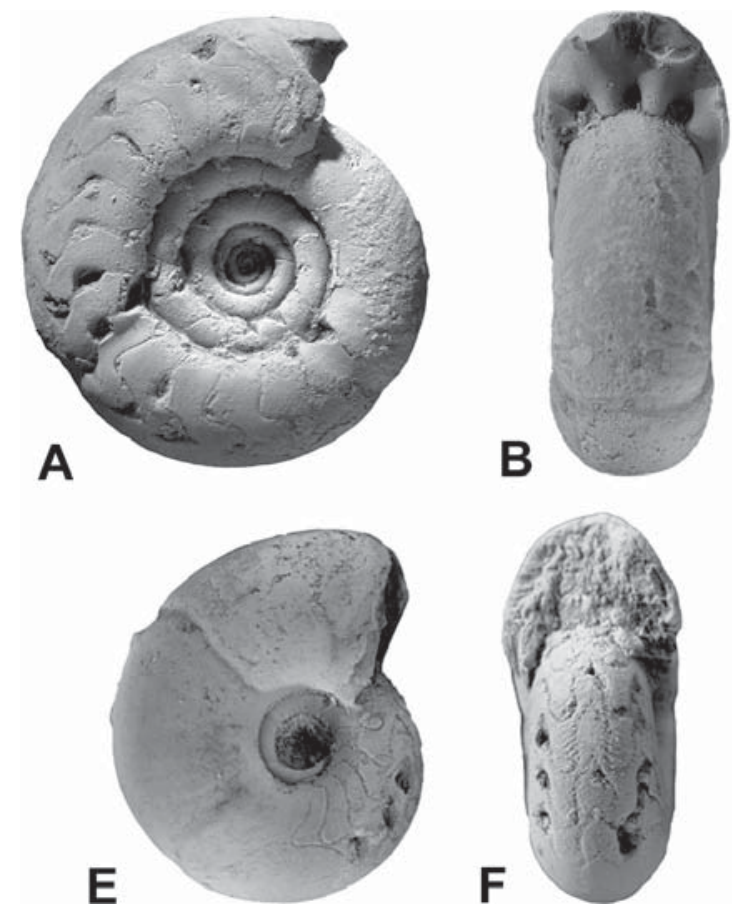

is slightly more expressed. MB.C.3837.3 (Fig. 34B) and MB.C.3837.5 (Fig. 34C) show a terminal whorl with slightly flattened flanks.

The holotype is with $20 \mathrm{~mm}$ conch diameter one of the largest specimens. Septal approximation in the last quarter of the whorl indicates adulthood of this specimen so that only the terminal body chamber is probably missing. It is thinly discoidal $(\mathrm{ww} / \mathrm{dm}=0.37)$ with a moderately wide umbilicus $(\mathrm{uw} / \mathrm{dm}=0.36)$. Within the last quarter of the whorl, there occurs a striking overlap of the whorl upon the preceding whorl, leading to a significant lowering of the uw/dm ratio. The specimen possesses four steinkern constrictions with almost linear course, only a very shallow ventral sinus can be seen. More than 25 septa can be counted on the last volution and a segment of the suture ontogeny can be studied. The last preserved septum shows a suture line (Fig. 34G) with a deep lanceolate external lobe, slightly deeper than the adventive lobe. The rounded ventrolateral saddle is almost perfectly symmetric, and the adventive lobe also has a symmetric V-shaped outline with barely sinuous flanks. The dorsolateral saddle is asymmetric and broadly rounded. About $300^{\circ}$ earlier, there is a shorter adventive lobe and a strikingly subangular dorsolateral saddle, showing a $90^{\circ}$ angle (Fig. 34F).
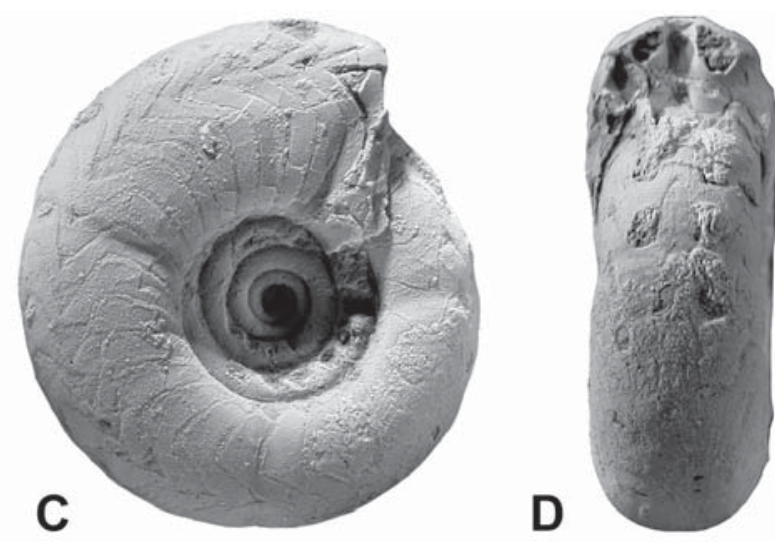

Fig. 35. Species of Weyerella from bed 9 of Mfis. A, B - Weyerella protecta n. sp., paratype MB.C.3837.2, lateral and dorsal views, $\times$ 2.5. C, D - Weyerella protecta n. sp., holotype MB.C.3837.1 (leg. R.T. Becker), lateral and dorsal views, $\times 2.5$. E, F - Weyerella minor n. sp., holotype MB.C.3838.1, lateral and dorsal views, $\times 4$. G, H - Weyerella minor n. sp., paratype MB.C.3838.2, dorsal and lateral views, $\times 4$. 
The smaller paratype MB.C.3837.2 (Fig. 35A, B) has, at $18 \mathrm{~mm}$ diameter, a conch that closely resembles the holotype, but is somewhat stouter $(\mathrm{ww} / \mathrm{dm}=0.42)$ with an almost circular whorl cross section and a wider umbilicus (uw/dm $=0.42$ ); the steinkern constrictions are weaker in this specimen. A smaller paratype MB.C.3837.8 is similar but has, at $4 \mathrm{~mm}$ whorl width, a ventrally depressed whorl cross section and also rather weak constrictions. The suture line of this specimen (Fig. 34E) has a pouched external lobe that is deeper than the very asymmetric adventive lobe. This has a steep ventral flank and a widely curved dorsal flank. This suture line has a conspicuous dorsolateral saddle with an asymmetric, hook-like indentation. Another small specimen, MB.C.3837.9 (Fig. 34D) has, at $8.5 \mathrm{~mm}$ conch diameter, a very similar conch shape and a similar suture line.

Discussion. The new species is very similar to W. molaris (Vöhringer, 1960), but a number of differences can be seen. W. molaris has, at comparable conch diameters, a narrower umbilicus (uw $/ \mathrm{dm}=0.30-0.35$ at $\mathrm{dm}=18 \mathrm{~mm})$ than
W. protecta $(\mathrm{uw} / \mathrm{dm}=0.38-0.44) . \quad W$. molaris shows a less angular dorsolateral saddle without such a deep external indentation.

Differences to W. minor n. sp. from Mfis are as follows: The whorl expansion rate decreases in W. protecta n. sp. during ontogeny (Fig. 34I), whereas it increases in W. minor n. sp. (Fig. 36G). W. mimica (Ruan, 1981) (uw/dm $=0.25-0.30$ at $\mathrm{dm}=19 \mathrm{~mm}$ ) and $W$. popanoides (Ruan, 1981) $(\mathrm{uw} / \mathrm{dm}=0.13$ at $\mathrm{dm}=17 \mathrm{~mm}$ and 0.17 at $\mathrm{dm}$ $=20 \mathrm{~mm}$ ) have a narrower umbilicus in contrast to W. protecta with $\mathrm{uw} / \mathrm{dm}=0.40-0.50$ at 15-20 mm diameter. W. angularia (Liang \& Wang, 1991) has a much longer adventive lobe. W. concava (Vöhringer, 1960) differs in the presence of a spiral groove on the inner flank.

\section{Weyerella minor $\mathbf{n}$. sp.}

Figs $35 \mathrm{E}-\mathrm{H}, 36$

Derivation of name. From Latin minor $=$ small; because of the small conch.

Holoty pe. MB.C.3838.1; figured here in Fig. 35 E, F.
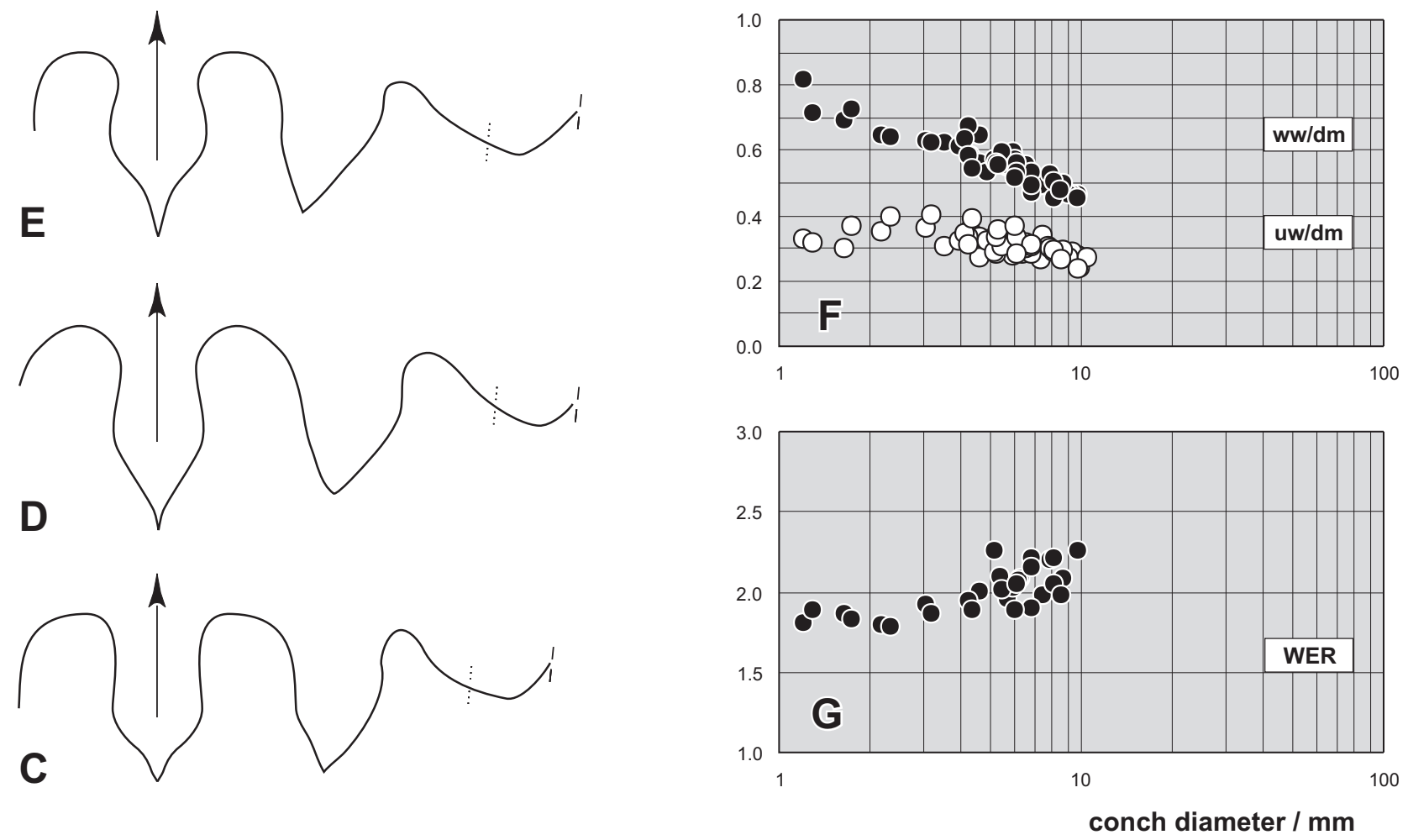

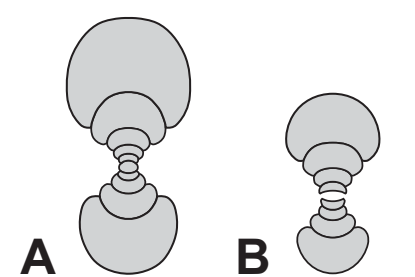

Fig. 36. Cross sections (A, B), suture lines (C - E) and bivariate plots (G, F) of Weyerella minor n. sp. from bed 7 and bed 9 of Mfis. A - paratype MB.C.3838.3 from bed $9, \times 3$. B paratype MB.C.3821.1 from bed 7, × 3. C - holotype MB.C.3838.1 from bed 9, at $\mathrm{dm}=6.4 \mathrm{~mm}, w w=3.4 \mathrm{~mm}, \times 12 . \mathbf{D}$ - paratype MB.C.3838.5 from bed 9 , at $\mathrm{dm}=7 \mathrm{~mm}$, $\mathrm{ww}=3.6 \mathrm{~mm}, \times 12 . \mathbf{E}-$ paratype MB.C.3838.4 from bed 9 , at $\mathrm{dm}=7.8 \mathrm{~mm}$, ww $=4 \mathrm{~mm}$, $\times 12$. F - Ontogenetic development of the whorl width index (ww/dm) and umbilical width index (uw/dm). G - Ontogenetic development of the whorl expansion rate (WER). 
Type locality and horizon. Northern slope of the Jebel Debouaâ east of Mfis (Anti-Atlas, Morocco); bed 9 (Early Tournaisian).

Material. Eleven moderately well-preserved specimens from bed 7 and 65 partly well-preserved specimens of up to maximally $11 \mathrm{~mm}$ diameter from bed 9 .

Diagnosis. Species of Weyerella with discoidal conch (ww/ $\mathrm{dm}=0.45-0.50)$ at $10 \mathrm{~mm}$ diameter; umbilicus moderately narrow (uw/dm $=0.25-0.30)$. Whorl expansion rate increasing during ontogeny to more than 2.00 at $10 \mathrm{~mm}$ diameter. Steinkern with concavo-convex constrictions. Suture line with wide, pouched external lobe and asymmetric adventive lobe. Adventive lobe shorter than the external lobe. Dorso-lateral saddle strikingly asymmetric and subangular.

Description. The individuals of the species are small. The cross sections of the specimens MB.C.3838.3 and MB.C.3821.1 (Fig. 36A, B) demonstrate that no significant ontogenetic changes occur up to a diameter of $8.5 \mathrm{~mm}$ and that mainly the whorl cross section undergoes changes from a ventrally depressed shape to a more circular. There is also no umbilical edge detectable; flanks and venter are continuously rounded. The ontogeny of the aperture shows a continuous increase: already at a conch diameter of $6 \mathrm{~mm}$ a WER value of more than 2.00 is reached.

The holotype belongs to the larger specimens. It has $9.5 \mathrm{~mm}$ conch diameter with a ww/dm ratio of 0.45 and an uw/dm ratio of 0.24 . The conch is laterally compressed and thickest in the midflank; the flanks converge towards the rounded venter. The umbilical wall is oblique and the umbilical edge widely rounded. More than half of the last volution belongs to the body chamber. This bears three steinkern constrictions with distances of $90^{\circ}$, whereas the phragmocone is not constricted. These constrictions are prorsiradiate on the flank, form a low projection in the ventrolateral position turning back to a shallow ventral sinus. Fine growth lines are occasionally preserved (Fig. 35E, F), following the course of the constrictions; between the constrictions, weak impressions of riblets are visible.

The suture line of paratype MB.C.3838.4 (Fig. 36E) has, at almost $8 \mathrm{~mm}$ conch diameter, a rather strongly pouched external lobe; the ventrolateral saddle is asymmetric and ventrally inclined, followed by a strikingly asymmetric Vshaped adventive lobe with steep ventral and diagonal dorsal flank. The dorsolateral saddle is also strikingly asymmetric and subangular. The external lobe is slightly deeper than the adventive lobe. The other two specimens, MB.C.3838.1 (Fig. 36C) and MB.C.3838.5 (Fig. 36D) display similar suture lines, demonstrating that some variability occurs in the shape of the external lobe, the base of the adventive lobe, and the shape of the dorsolateral saddle.

Discussion. W. minor n. sp. differs from W. molaris (Vöhringer, 1960) and the other species of the genus by the relatively narrow umbilicus (uw/dm $=0.25-0.30$ at $\mathrm{dm}=10 \mathrm{~mm}$ ), and the rather rapid increase of the aperture height (WER > 2.00 already at $\mathrm{dm}=6 \mathrm{~mm}$ ).

Order Prolecanitida Miller \& Furnish, 1954

Superfamily Prolecanitoidea Hyatt, 1884

Family Prolecanitidae Hyatt, 1884

Subfamily Prolecanitinae Hyatt, 1884

\section{Eocanites Librovich, 1957}

Type species. Protocanites supradevonicus (Schindewolf, 1926)

\section{Eocanites simplex n. sp.}

Figs 37A-E, 38I-K

Derivation of name. From Latin simplex, because of the rather simple suture line.

Holotype. MB.C.3841.1; figured here in Fig. 38J, K.

Type locality and horizon. Ma'der, Aguelmous, Bou Tlidat, (N 30 58'973" W 04 51'234", Anti-Atlas, Morocco); bed $2 b$ (Early Tournaisian).

Material. Eight specimens from Bou Tlidat and one fragment from bed $1 \mathrm{c}$ of Mfis.

Diagnosis. Species of Eocanites with very thin, discoidal conch $(\mathrm{ww} / \mathrm{dm}=0.40)$ at $10 \mathrm{~mm}$ diameter; umbilicus wide $(\mathrm{uw} / \mathrm{dm}=0.50)$. Whorl expansion rate 1.80-1.90. Coarse, rectiradiate growth lines. Suture line with deep, pouched external lobe, strikingly asymmetric adventive lobe, and very shallow lateral lobe.

Description. The holotype (almost $9 \mathrm{~mm}$ diameter) is a discoidal, serpenticonic conch (ww/ $\mathrm{dm}=0.40$ ) with barely embracing whorls and wide umbilicus $(\mathrm{uw} / \mathrm{dm}=0.50)$. The whorl cross section is ventrally slightly depressed (ww/dm $=1.50$ ), with rounded flanks and venter. The steinkern bears weak, rounded riblets, best visible in the ventrolateral portion where they form a very low projection, turning back to a very low ventral sinus.

The suture line possesses a very deep, pouched external lobe, 1.5 times deeper than the adventive lobe, a continuously rounded ventrolateral saddle, an asymmetric, subacute adventive lobe, a very asymmetric, narrowly rounded dorsolateral saddle and a low and narrowly rounded lateral lobe (Fig. 37B). 

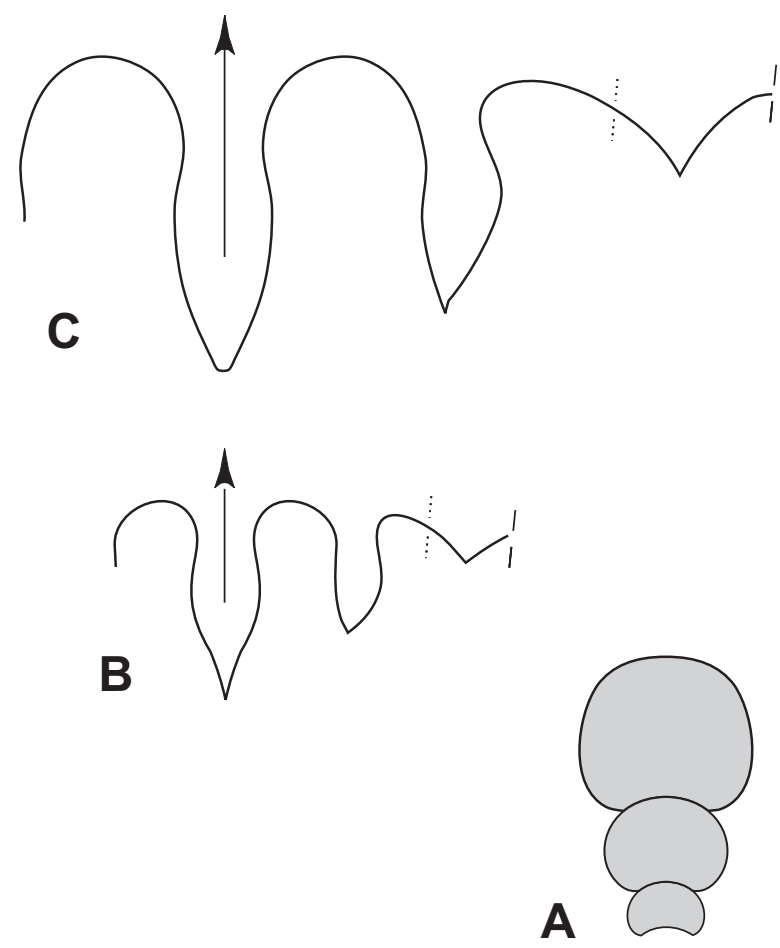
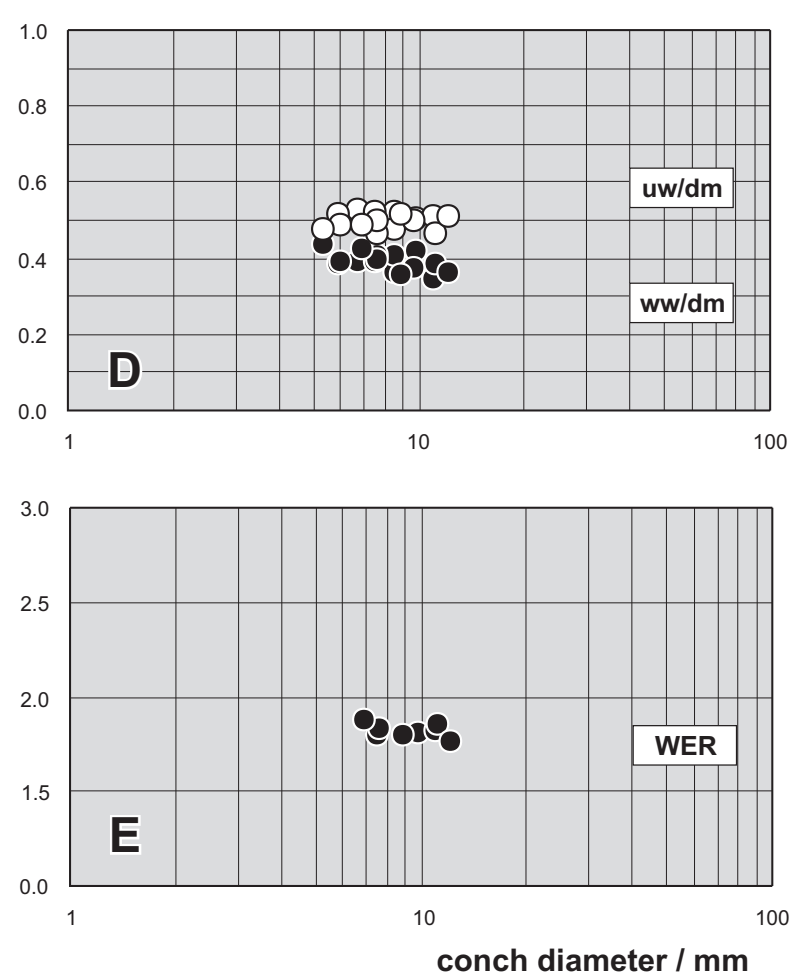

Fig. 37. Cross section (A), suture lines (B, C) and bivariate plots (D, E) of Eocanites simplex n. sp. from bed 1c of Mfis and bed $2 \mathrm{~b}$ of Bou Tlidat (Aguelmous). A - paratype MB.C.3841.2 from Bou Tlidat $\times 3$. B - holotype MB.C.3841.1 at $\mathrm{dm}=9.9 \mathrm{~mm}, w \mathrm{w}=3.7 \mathrm{~mm}$ from Bou Tlidat $\times 7$. C - paratype MB.C.3812 from bed 1c of Mfis, at wh $=6.4 \mathrm{~mm}$, ww $=5 \mathrm{~mm}, \times 7 . \mathbf{D}-$ Ontogenetic development of the whorl width index (ww/dm) and umbilical width index (uw/dm). E Ontogenetic development of the whorl expansion rate (WER).

Paratype MB.C.3812 (Fig. 37C, 38I) from Mfis is a fragment of a larger specimen with a slightly flattened venter, but otherwise similar conch morphology. The suture line represents a more advanced ontogentic stage in which the adventive lobe is now deeper, but still conspicuously asymmetric.

D iscussion. Eocanites simplex n. sp. is similar to E. nodosus (Schmidt, 1925). Striking differences can be seen in the suture line, particularly in the much narrower and pouched external lobe, the narrow and asymmetric adventive lobe and the asymmetric dorsolateral saddle. The wide, ventrally depressed whorl cross section is, in addition to the characteristics listed above, a criterion for a separation from the other species of Eocanites.

\section{Eocanites rtbeckeri n. sp.} Figs 38G, H, L, M 39

Derivation of name. In honour of Ralph Thomas Becker (Münster) who accompanied us on numerous occasions to Morocco and gave valuable advice in the field.

Holoty pe. MB.C.3839.1; figured here in Fig. 38G, H.

Type locality and horizon. Northern slope of the Jebel Debouaâ east of Mfis (Anti-Atlas, Morocco); bed 9 (Early Tournaisian)
Material. 92 steinkern specimens from bed 9, partly wellpreserved with a conch diameter of up to $26 \mathrm{~mm}$.

Diagnosis. Species of Eocanites with thin, discoidal conch (ww/dm $=0.30-0.35$ at $\mathrm{dm}=15 \mathrm{~mm}$; umbilicus wide $(\mathrm{uw} / \mathrm{dm}$ $=0.50$ ). Whorl cross section subquadrate; whorl expansion rate 1.80-1.90. Ornament with lamellose rursiradiate growth lines. Suture line with pouched external lobe and asymmetric, slightly pouched adventive lobe and rather deep, hookshaped lateral lobe.

Description. All growth stages display a similar conch geometry with a trend towards a more slender conch (ww/dm is reduced from 0.45 at $\mathrm{dm}=2.5 \mathrm{~mm}$ to $<0.30$ at $\mathrm{dm}=25 \mathrm{~mm}$; Fig. 39E). The sectioned paratype MB.C.3839.5 $(\mathrm{dm}=16 \mathrm{~mm})($ Fig. 39A) allows the study of the conch ontogeny and the transition from the ventrally depressed, crescent-shaped whorl cross section in early juveniles, to the subquadrate cross section of large individuals. The whorls embrace the preceding only to a minor degree.

The holotype is a well-preserved specimen of $12 \mathrm{~mm}$ conch diameter with some attached shell remains. It is a thinly discoidal conch (ww/dm $=0.33$ ) with an almost circular whorl cross section and has a wide umbilicus ( $\mathrm{uw} / \mathrm{dm}=0.49)$. It displays fine growth lines that extend in rursiradiate direction, with a shallow ventral sinus across flanks and venter. The suture line of this 

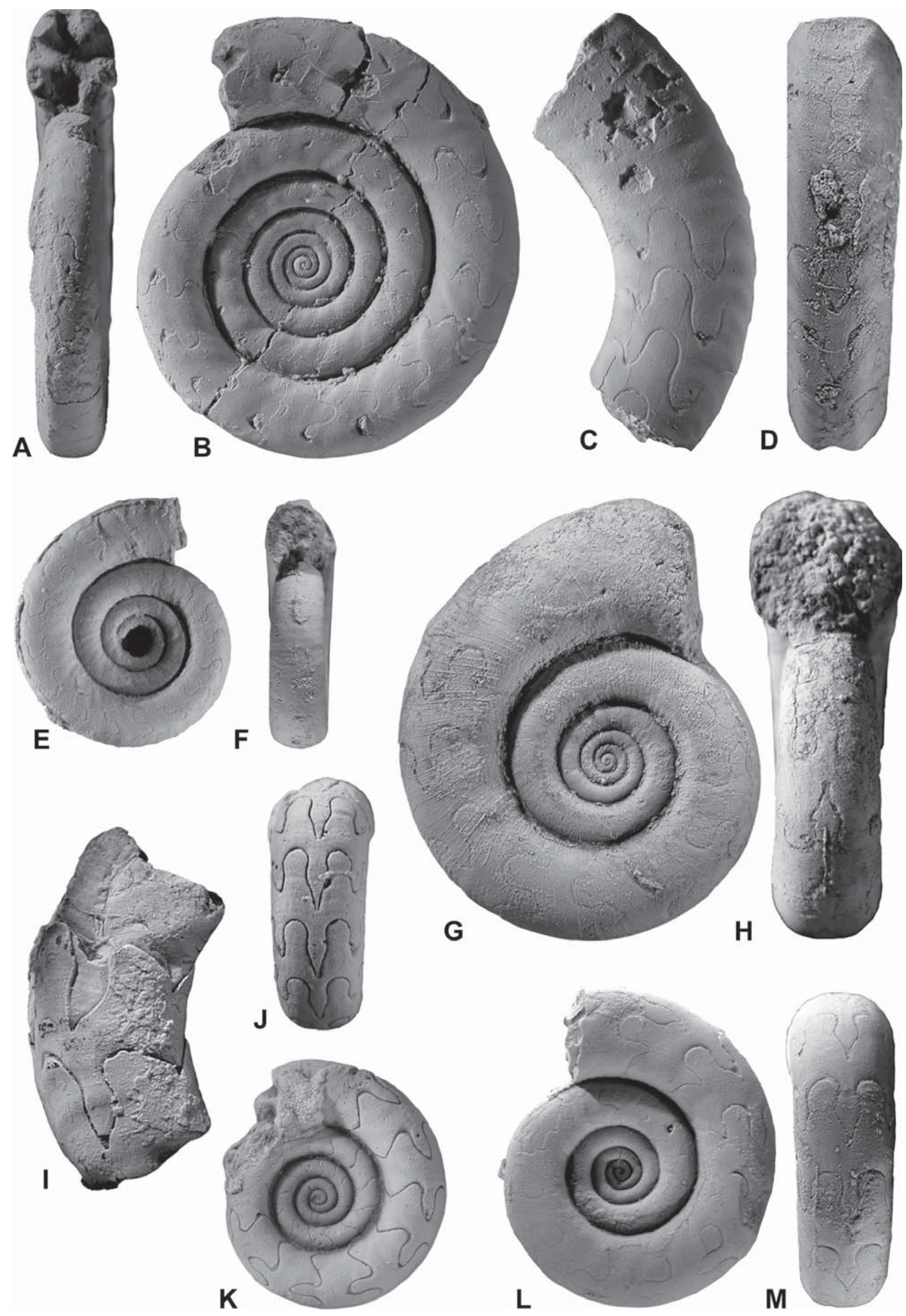

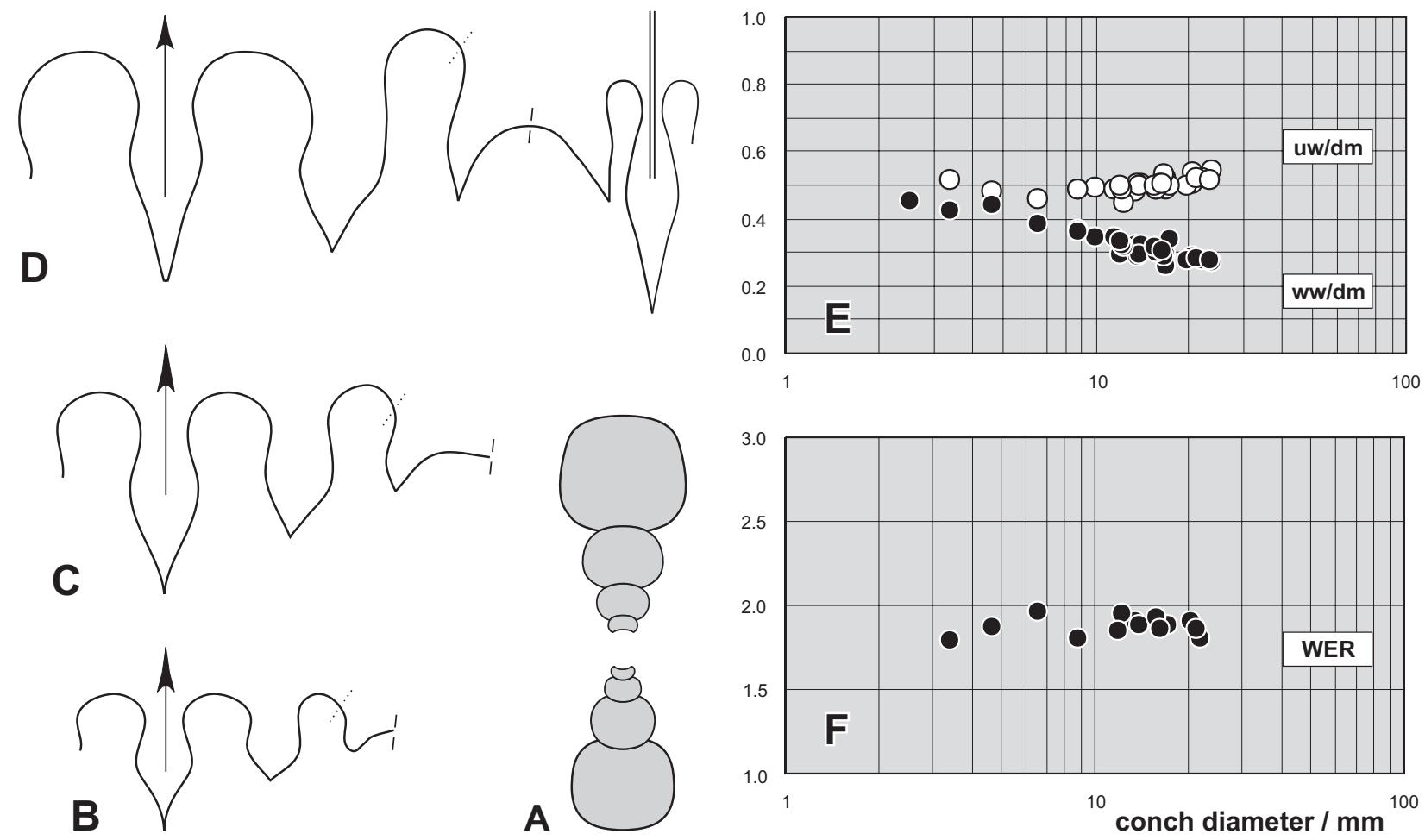

Fig. 39. Cross section (A), suture lines (B - D) and bivariate plots (E, F) of Eocanites rtbckeri n. sp. from bed 9 of Mfis. A paratype MB.C.3839.5, $\times 3 . \mathbf{B}-$ paratype MB.C. 3839.4 at $\mathrm{dm}=6.6 \mathrm{~mm}$, ww $=6.6 \mathrm{~mm} \times 7$. C - paratype MB.C.3839.2 at $\mathrm{dm}=7.5 \mathrm{~mm}, \mathrm{wh}=2.4 \mathrm{~mm}, \mathrm{ww}=3 \mathrm{~mm}, \times 7 . \mathbf{D}-$ paratype MB.C. 3839.3 at $\mathrm{dm}=12 \mathrm{~mm}, \mathrm{wh}=3.5 \mathrm{~mm}, \mathrm{ww}=5.5 \mathrm{~mm}, \times 5$. E - Ontogenetic development of the whorl width index (ww/dm) and umbilical width index (uw/dm). F - Ontogenetic development of the whorl expansion rate (WER).

specimen has a deep, pouched external lobe, which is the dominant element. It is almost 1.5 times deeper than the adventive lobe).

In MB.C.3839.4 (Fig. 39B) the external lobe is also very deep, amphora-shaped and widest at half depth. The ventrolateral saddle is broadly rounded and the adventive lobe asymmetric and acute, with the ventral side more sinuous than the dorsal side. The adventive lobe is a little shorter than the external lobe. On the flank follows a narrow dorsolateral saddle and a hookshaped lateral lobe on the umbilical wall.

Discussion. The new species differs from most of the other species within the genus in the weak ornament. Similar is E. supradevonicus, which has a rounded, i.e., circular to oval, whorl cross section. The suture line closely resembles that of E. wangyuensis Ruan, 1981, but this species bears ribs and has a higher aperture.

\section{Eocanites dkorni n. sp.}

Figs 38A-F, 40

Derivation of name. In honour of Dieter Korn (Berlin) for the support in the preparation of specimens and with electronic imaging techniques.

Holotype. MB.C.3840.1; figured here in Fig. 38A, B.

Type locality and horizon. Northern slope of the Jebel Debouaâ east of Mfis (Anti-Atlas, Morocco); bed 9 (Early Tournaisian)

Material. One well-preserved phragmocone of $17 \mathrm{~mm}$ diameter (the holotype) and two whorl fragments from bed 9, and one specimen of $9 \mathrm{~mm}$ diameter from bed 7 .

Diagnosis. Species of Eocanites with very thin, discoidal conch $(\mathrm{ww} / \mathrm{dm}=0.20)$ at $15 \mathrm{~mm}$ diameter; umbilicus very wide $(\mathrm{uw} / \mathrm{dm}=0.60)$. Steinkern with backwards directed, shallow and weak riblets. Suture line with parallel-sided external lobe and lanceolate adventive lobe.

Description. The holotype (Fig. 38A, B) has a diameter of $16.5 \mathrm{~mm}$ and displays a uniquely slender conch morphology $(\mathrm{ww} / \mathrm{dm}=0.20)$ with a very wide umbilicus $(\mathrm{uw} / \mathrm{dm}=0.60)$. The

Fig. 38. Species of Eocanites from bed 1c, bed 7 and bed 9 of Mfis and from bed 2 of Bou Tlidat, Aguelmous (J, K). A, B Eocanites dkorni n. sp., holotype MB.C.3840.1 from bed 9 of Mfis, dorsal and lateral views, $\times 5$. C, D - Eocanites dkorni n. sp., paratype MB.C.3840.2 from bed 9 of Mfis, lateral and ventral views, $\times$ 5. E, F - Eocanites dkorni n. sp., MB.C.3822 from bed 7 of Mfis, lateral and dorsal views, $\times 5$. G, $\mathbf{H}-$ Eocanites rtbeckeri n. sp., holotype MB.C.3839.1 from bed 9 of Mfis, lateral and dorsal views, $\times 5$. I - Eocanites simplex n. sp., paratype MB.C.3812 from bed $1 \mathrm{c}$ of Mfis, latral view, $\times 5$. J, $\mathbf{K}-$ Eocanites simplex n. sp., holotype MB.C.3841.1 from bed 2 of Bou Tlidat, Aguelmous, ventral and lateral views, $\times 5$. L, M Eocanites rtbeckeri n. sp., paratype MB.C.3839.3 from bed 9 of Mfis, lateral and ventral views, $\times 5$. 


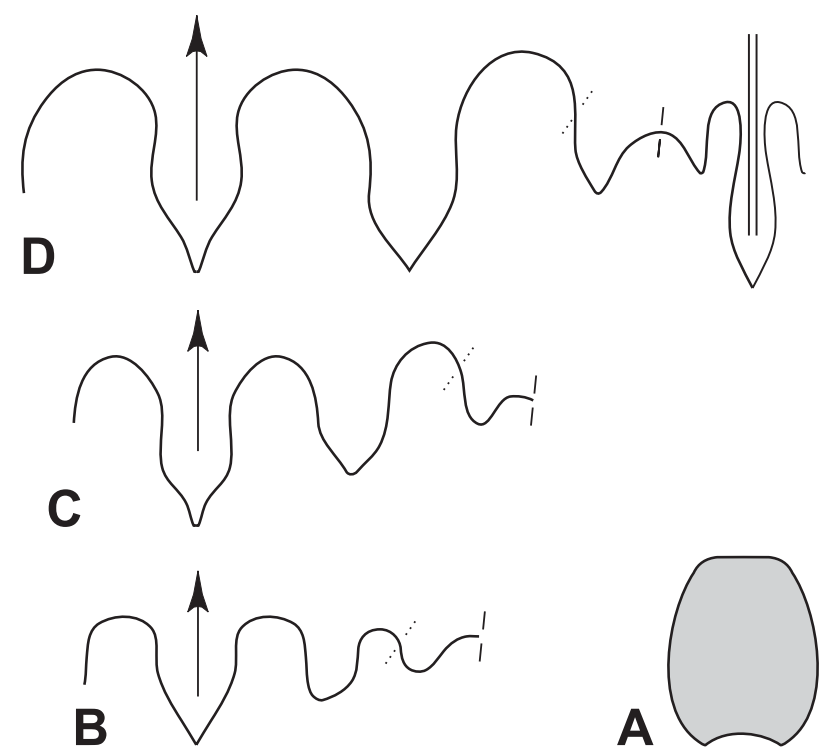

Fig. 40. Cross section (A) and suture lines (B - D) of Eocanites dkorni n. sp. from bed 7 and bed 9 of Mfis. A - paratype MB.C.3840.2 from bed $9 \times 3$. B - MB.C.3822 from bed 7 , at $\mathrm{dm}=9.8 \mathrm{~mm}, \quad w w=3.6 \mathrm{~mm}, \quad \times 8 . \quad \mathbf{C}-$ holotype MB.C. 3840.1 from bed 9 , at $\mathrm{dm}=15 \mathrm{~mm}$, wh $=3.4 \mathrm{~mm}, \times 8$. D - paratype MB.C. 3840.2 from bed 9 , at $w h=5.3 \mathrm{~mm}$, $\mathrm{ww}=4.3 \mathrm{~mm}, \times 7$.

flanks stand parallel and are only slightly rounded; the venter is broadly rounded. This means that the whorl cross section is laterally compressed, with a ww/wh ratio $=0.80$. Numerous weak riblets (approximately 20-25 per whorl) are best visible on the inner flanks; they are aligned backwards. The suture line (Fig. 40C) can be regarded as immature; it has a lanceolate external lobe and a much shorter, subacute adventive lobe; the lateral lobe is still rounded.

The suture line of the larger fragment MB.C.3840.2 (Fig. 40D) is typical for Eocanites; it has a lanceolate external lobe that is almost half as wide as deep. The ventrolateral saddle is almost symmetric and the adventive lobe resembles the external lobe, in size as well as in shape. This fragment possesses some of the ornament characteristics of the holotype but differs in the tabular venter. One whorl earlier, the venter is still rounded as in the holotype.

Discussion. Eocanites dkorni n. sp. differs in the extremely slender and widely umbilicate conch morphology and the rursiradiate riblets from all other species of the genus.

\section{Acknowledgements}

We are especially indebted to Dieter Korn (Museum für Naturkunde der Humboldt-Universität zu Berlin), who gave important input for the improvement of our paper; to Dieter
Weyer (Berlin) who helped us with literature and classified the additional fauna of the assemblages; Ralph Thomas Becker and Zhor Sarah Aboussalam (Westfälische WilhelmsUniversität Münster, Germany) have accompanied us on numerous occasions to Morocco and gave valuable advice in the field. Knut Hahne (GeoForschungsZentrum Potsdam) analysed sedimentological samples. We are also indebted to the Moroccan authorities, particularly Ahmed El Hassani (Institut Scientifitique, Rabat) for their kind support and hospitality. Finally we thank Christian Klug (Paläontologisches Institut und Museum der Universität Zürich) and Alistair McGowan (British Museum of Natural History) for their critical reviews of the manuscript.

\section{References}

Bartzsch, K. \& Weyer, D. 1982. Zur Stratigraphie des Untertournai (Gattendorfia-Stufe) von Saalfeld im Thüringischen Schiefergebirge. - Abhandlungen und Berichte für Naturkunde und Vorgeschichte 12 (4): 3-54.

- 1986. Biostratigraphie der Devon/Karbon-Grenze im Bohlen-Profil bei Saalfeld (Thüringen, DDR). - Zeitschrift für geologische Wissenschaften 14: 147-152.

- 1987. Das unterkarbonische Ammonoidea-Tribus Pseudarietini. - Abhandlungen und Berichte für Naturkunde und Vorgeschichte 13: 59-68.

Becker, R. T. 1993. Analysis of ammonoid palaeogeography in relation to the global Hangenberg (terminal Devonian) and lower Alum Shale (Middle Tournaisian) Events. Annales de la Société géologique de Belgique 115 (2): 459-473.

- 1996. New faunal records and holostratigraphic correlation of the Hasselbachtal D/C-boundary auxilliary stratotype (Germany). - Annales de la Société géologique de Belgique 117 (1): 19-45.

Becker, R. T. \& House, M. R. 2000. The Famennian ammonoid succession at Bou Tchrafine (Anti-Atlas, southern Morocco). - Notes et Mémoires du Service Géologique 399: 49-56.

Becker, R. T., House, M. R., Bockwinkel, J., Ebbighausen, V. \& Aboussalam, S. 2002. Famennian ammonoid zones of the eastern Anti-Atlas (southern Morocco). - Münstersche Forschungen zur Geologie und Paläontologie 93: 159-205.

Becker, R. T. \& Weyer, D. 2004. Bartzschiceras n. gen. (Ammonoidea) from the Lower Tournaisian of Southern France. - Mitteilungen aus dem Geologisch-Paläontologischen Institut der Universität Hamburg 88: 11-36.

Choubert, G., Clariond, L. \& Hindermeyer, J. 1952. Livret Guide de l'Excursion C 36. Anti-Atlas Central et Oriental. - Congrès Géologique International, XIX ${ }^{\mathrm{e}}$ Session, Alger 1952: 1-89; Rabat.

Conrad, J. 1984. Les séries Carbonifères du Sahara Central Algérien; stratigraphie, sédimentation, évolution structurale. - Université de Droit, d' Economie et des Sciences d'Aix Marseille. Thèse de Doctorat d'Etat ès-Sciences naturelles: $370 \mathrm{pp}$; Marseille.

Conrad, J., Pareyn, C. \& Weyant, M. 1970. Mise en évidence $\mathrm{du}$ Tournaisien inférieur dans la vallée de la Saoura (Sahara nord-occidental) et conséquences paléogéographiques. - Compte Rendus Hebdomadaires des Séances de l'Académie des Sciences (Paris), Série D: Sciences Naturelles 271 (11): 900-903.

Dzik, J. 1997. Emergence and succession of Carboniferous conodont and ammonoid communities in the Polish part of the Variscan Sea. - Acta Palaeontologica Polonica 42 (1): 57-170.

Ebbighausen, V., Bockwinkel, J., Korn, D. \& Weyer, D. 2004. Early Tournaisian ammonoids from Timimoun (Gourara, Algeria). - Mitteilungen aus dem Museum für Naturkunde in Berlin, Geowissenschaftliche Reihe 7: 133-152. 
Frech, F. 1897-1902. Lethaea geognostica oder Beschreibung und Abbildung der für die Gebirgs-Formationen bezeichnendsten Versteinerungen. I. Theil. Lethaea palaeozoica. 2. Band. IV. - 257-452; Stuttgart (Schweizerbart). pp. 1-283: 1897, pp. 284-471: 1899, pp. 472ff.: 1902.

- 1902. Über devonische Ammoneen. - Beiträge zur Paläontologie Österreich - Ungarns und des Orients 14: 27-112.

Hall, J. 1860. Notes and observations upon fossils of the Goniatite Limestone in the Marcellus shale of the Hamilton group, in the eastern and central parts of the State of New York, and those of the Goniatite beds of Rockford, Indiana; with some analogous forms from the Hamilton group proper. - Annual Reports of the Regents of the University of the State New York, on the condition of the State Cabinet of Natural History, and the Historical and Antiquarian Collection annexed thereto 13: $59-112$.

Hollard, H. 1956. Sur le Tournaisien de la vallée du Dra. Compte Rendus Hebdomadaires des Séances de l'Académie des Sciences 242: 2752-2755.

- 1958. Découverte des Goniatites tournaisiennes dans le Maider (Province du Tafilalet, Maroc). - Comptes Rendus Hebdomadaires des Séances de l'Académie des Sciences 247: 789-792.

- 1960. Extension du Tournaisien dans la région de Taouz et dans le sud du Tafilalt (Maroc). - Comptes Rendus Hebdomadaires des Séances de l'Académie des Sciences 250 (4): 733-735.

- 1970. Sur la transgression Dinantienne au Maroc présaharien. - Compte Rendu $6^{\mathrm{e}}$, Congrès International de Stratigraphie et de Géologie du Carbonifère 3: 923-936.

Hyatt, A. 1883-1884. Genera of the fossil cephalopods. Proceedings of the Boston Society of Natural History 22: 253-338 (253-272 publ. 1883, 237-238 publ. 1884).

Kaiser, S. I. 2005. Mass extinction, climatic and oceanographic changes at the Devonian/Carboniferous boundery. - Dissertation zur Erlangung des akademischen Grades eines Doktors der Naturwissenschaften an der Fakultät für Geowissenschaften der Ruhr-Universität Bochum (Germany), 156 pp; Bochum.

Koninck, L. G. de 1842-1844. Description des animaux fossils qui se trouvent dans le terrain carbonifère de Belgique. -650 pp., Dessin, Liège.

Korn, D. 1984. Die Goniatiten der Stockumer ImitocerasKalklinsen (Ammonoidea; Devon/Karbon-Grenze). Courier Forschungsinstitut Senckenberg 67: 71-89.

- 1988. Oberdevonische Goniatiten mit dreieckigen Innenwindungen. - Neues Jahrbuch für Geologie und Paläontologie, Monatshefte 1988 (10): 605-610.

- 1992a. Ammonoideen aus dem Devon/Karbon-Grenzprofil an der Grünen Schneid (Karnische Alpen, Österreich). - Jahrbuch der Geologischen Bundesanstalt 135: 7-19.

- 1992b. Heterochrony in the evolution of Late Devonian Ammonoids. - Acta Palaeontologica Polonica 37 (1): $21-36$.

- 1993. The ammonoid faunal change near the DevonianCarboniferous boundary. - Annales de la Société Géologique de Belgique 115 (for 1992): 581-593.

- 1994. Oberdevonische und unterkarbonische Prionoceraten aus dem Rheinischen Schiefergebierge. - Geologie und Paläontologie in Westfalen 30: 1-85.

- 1997. The Palaeozoic ammonoids of the South Portuguese Zone. - Memórias do Instituto Geológico e Mineiro de Portugal 33: 1-132.

- 1999. Famennian Ammonoid Stratigraphy of the Ma'der and Tafilalt (Eastern Anti-Atlas, Morocco). - Abhandlungen der Geologischen Bundesanstalt 54: 147-179.

Korn, D., Bockwinkel, J., Ebbighausen, V. \& Klug, C. 2003. Palaeogeographic and evolutionary meaning of an early Late Tournaisian (Early Carboniferous) ammonoid fauna from the Tafilalt of Morocco. - Acta Palaeontologica Polonica 48 (1): 71-92.
Korn, D., Ebbighausen, V., Bockwinkel, J. \& Klug, C. 2003. The A-mode sutural ontogeny in prolecanitid ammonoids. - Palaeontology 46 (6): 1123-1132.

Korn, D. \& Klug, C. 2002. Ammoneae Devonicae. In: W. Riegraf (Ed.), Fossilium Catalogus, Animalia I, 138: xviii +375 pp., Backhuys, Leiden.

Korn, D., Klug, C., Ebbighausen, V. \& Bockwinkel, J. 2002. Palaeogeographical meaning of a Middle Tournaisian ammonoid fauna from Morocco. - Geologica et Palaeontologica 36: 79-86.

Korn, D. \& Vöhringer, E. 2004. Allometric growth and intraspecific variability in the basal Carboniferous ammonoid Gattendorfia crassa Schmidt, 1924. - Paläontologische Zeitschrift 78 (2): 419-426.

Korn, D. \& Weyer, D. 2003. High resolution stratigraphy of the Devonian-Carboniferous transitional beds in the Rhenish Mountains. - Mitteilungen aus dem Museum für Naturkunde in Berlin, Geowissenschaftliche Reihe 6: 79-124.

Kullmann, J. \& Korn, D. 2001. Goniat-Paleozoic Ammonoid Database System, Version 3.00. - Geologisch-Paläotolosches Institut, Tübingen.

Kuzina, L. F. 1985. K revizii roda Imitoceras (Ammonoidea). - Paleontologicheskiy Zhurnal 1985 (3): 35-48.

Lange, W. 1929. Zur Kenntnis des Oberdevons am Enkeberg und bei Balve (Sauerland). - Abhandlungen der Preußischen Geologischen Landesanstalt, Neue Folge 119: $1-132$.

Liang, Xi-luo. 1976. Carboniferous and Permian ammonoids from the Mount Jolmo Lungma region. A Report on Scientific expedition in the Mount Iolmo Lungma region, 1966-1968. - Paleontologica Sinica 3: 215-220.

Liang, Xi-luo \& Wang, Ming-qian. 1991. Carboniferous cephalopods of Xinjiang. - Paleontologica Sinica, n. ser. B 180: $1-171$.

Librovich, L. S. 1940. Ammonoidea iz kamennougolnykh otlozheniy Severnogo Kazakhstana. - Paleontologiya SSSR 4 (9/1): VI + 392 pp.

- 1957. O nekotorykh novykh gruppakh goniatitov iz kamennougolnykh otlozheniy SSSR. - Ezhegodnik Vsesoyuznogo Paleontologicheskogo Obshchestva 16: $246-272$.

Manger, W. L. 1971. The Mississipian ammonoids Karagandoceras and Kazakhstania from Ohio. - Journal of Paleontology 45 (1): 33-39.

Meyendorff, A. 1939. Les couches de passage du Dévonien au Carbonifère dans le Gourara. - Comptes Rendus Hebdomadaires des Séances de l'Académie des Sciences 209: $228-229$.

Miller, A. K. \& Furnish, W.M. 1954. The classification of the Paleozoic ammonoids. - Journal of Paleontology 28: 685-692.

Miller, A. K. \& Garner, H. F. 1955. Lower Mississippian cephalopods of Michigan. Part III. Ammonoids and Summary. - Contributions from the Museum of Paleontology University of Michigan 12 (8): 113-173.

Morton, S. G. 1836. Being a notice and description of the organic remains embraced in the preceding. - in Hildreth, S. P.: Observations on the Bituminous Coal deposit of the Valley of the Ohio. - American Journal of Science 29: 149-154.

Münster, G. Graf zu 1832. Über die Planuliten und Goniatiten im Uebergangs-Kalk des Fichtelgebirges. - 38 pp, Birner, Bayreuth.

- 1839. Nachtrag zu den Goniatiten des Fichtelgebirges. Beiträge zur Petrefaktenkunde 1: 43-55.

Popov, A. V. 1975. Ammonoidea (Ammonoids). - In: Stepanov, D. L. et al., (Eds.): Paleontologicheskiy atlas kamennougol'nykh otlozheniy Urala. - Trudy, Vsesoyuznyy Neftyanoy Nauchno-Issledovatel'skiy Geologorazvedochnyy Institut (VNIGRI), 383: 111-130, 230-235.

Ruan, Yi-ping 1981. Devonian and earliest Carboniferous ammonoids from Guangxi and Guizhou. - Memoirs of 
Nanjing Institute of Geology and Palaeontology, Academia Sinica 15: $1-152$.

Ruzhencev, V. E. 1950. Verkhnekamennougol'nye ammonity Urala. - Trudy Paleontologicheskogo Instituta Akademiya Nauk SSSR 29: 1-223.

Sadykov, A. M. 1962. Srednepaleozoyskie dvustvorchatye mollyuski Atasu (Tsentral'nyy Kazakhstan). - Institut Geologicheskikh Nauk (Akademiya Nauk Kazakhskoy SSR): 1-114; Almaty.

Schindewolf, O.H. 1920. Neue Beiträge zur Kenntnis der Stratigrphie und Paläontologie des deutschen Oberdevons. - Senckenbergiana 2 (3/4): 114-129.

- 1923. Beiträge zur Kenntnis des Paläozoikums in Oberfranken, Ostthüringen und dem Sächsischen Vogtlande. I. Stratigraphie und Ammoneenfauna des Oberdevons von Hof a. S. - Neues Jahrbuch für Mineralogie, Geologie und Paläontologie, Beilageband 49: 250-357, 393-509.

- 1924. Bemerkungen zur Stratigraphie und Ammonoideenfauna des Saalfelder Oberdevons. - Senckenbergiana 6: $95-113$

- 1926. Zur Kenntnis der Devon-Karbon-Grenze in Deutschland. - Zeitschrift der Deutschen Geologischen Gesellschaft 78: 88-133.

- 1952. Über das Oberdevon und Unterkarbon von Saalfeld in Ostthüringen. Eine Nachlese zur Stratigraphie und Ammoneen-Fauna. - Senckenbergiana 32: 281-306.

Schmidt, H. 1921. Das Oberdevon-Culm-Gebiet von Warstein i. W. und Belecke. - Jahrbuch der Preußischen Geologischen Landesanstalt 41 (1/2) (for 1920): 254-339.

- 1924. Zwei Cephalopodenfaunen an der Devon-Carbongrenze im Sauerland. - Jahrbuch der Preußischen Geologischen Landesanstalt 44 (for 1923): 98-171.

- 1925. Die carbonischen Goniatiten Deutschlands. - Jahrbuch der Preußischen Geologischen Landesanstalt 45 (for 1924): 489-609.
Sheng, Huaibin 1984. Lower Carboniferous ammonoid faunule from the Zhifang area, Xinjiang. - Acta Geologica Sinica 4: 284-292.

Vöhringer, E. 1960. Die Goniatiten der unterkarbonischen Gattendorfia-Stufe im Hönnetal (Sauerland). - Fortschritte in der Geologie von Rheinland und Westfalen $\mathbf{3}$ (1): 107-196.

Wedekind, R. 1918. Die Genera der Palaeoammonoidea (Goniatiten). Mit Ausschluß der Mimoceratidae, Glyphioceratidae und Prolecanitidae. - Palaeontographica 62: 85-184.

Wendt, J. 1988. Facies pattern and paleogeography of the Middle and Late Devonian in the eastern Anti-Atlas (Morocco). - In: McMillan, N. J., Embry \& A. F., Glass, D. J. (Eds.): Devonian of the World, Canadian Society of Petroleum Geologists, Memoir 14 (1): 467-480.

Wendt, J., Aigner, T. \& Neugebauer, J. 1984. Cephalopod limestone deposition on a shallow pelagic ridge: the Tafilalt Platform (Upper Devonian, eastern Anti-Atlas, Morocco). - Sedimentary Geology 33: 601-625.

Weyer, D. 1965. Zur Ammonoideen-Fauna der GattendorfiaStufe von Dzikowiec (Ebersdorf) in Dolny Śląsk (Niederschlesien), Polen. - Berichte der Geologischen Gesellschaft in der DDR 10: 443-464.

- 1972. Zum Alter der Ammonoideen-Fauna des MarshallSandsteins (Unterkarbon; Michigan, USA). - Berichte der deutschen Gesellschaft für geologische Wissenschaften, A, Geologie, Paläontologie 17 (3): 325-350.

- 1976. Ein neues Ammonoideen-Genus aus dem Untertournai des Thüringischen Schiefergebierges. - Zeitschrift für geologische Wissenschaften 4 (6): 837-857.

- 1977. Ammonoideen aus dem Untertournai von Schleiz (Ostthüringisches Schiefergebirge). - Zeitschrift für geologische Wissenschaften 5: 167-185.

\section{Appendix}

Conch dimensions and ratios of ammonoids from Mfis.

\begin{tabular}{|c|c|c|c|c|c|c|c|c|c|c|}
\hline & $\mathrm{dm}$ & ww & wh & uw & ah & $\mathrm{ww} / \mathrm{dm}$ & ww/wh & $\mathrm{uw} / \mathrm{dm}$ & WER & IZR \\
\hline \multicolumn{11}{|c|}{ Mimimitoceras hoennense Korn, 1993} \\
\hline $\begin{array}{l}\text { MB.C. } 3823.3 \\
\text { MB.C. } 2823.4\end{array}$ & $\begin{array}{r}11.52 \\
14.57 \\
9.09 \\
5.80 \\
3.69 \\
2.46 \\
1.66 \\
1.01\end{array}$ & $\begin{array}{l}8.43 \\
9.97 \\
6.95 \\
4.65 \\
3.27 \\
2.21 \\
1.53 \\
0.91\end{array}$ & $\begin{array}{l}6.25 \\
8.16 \\
5.00 \\
3.11 \\
1.95 \\
1.21 \\
0.74 \\
0.46\end{array}$ & $\begin{array}{l}0.79 \\
0.17 \\
0.13 \\
0.20 \\
0.13 \\
0.24 \\
0.27 \\
0.16\end{array}$ & $\begin{array}{l}3.18 \\
1.82 \\
1.20 \\
0.68 \\
0.44 \\
0.32 \\
0.26\end{array}$ & $\begin{array}{l}0.73 \\
0.68 \\
0.77 \\
0.80 \\
0.89 \\
0.90 \\
0.92 \\
0.90\end{array}$ & $\begin{array}{l}1.35 \\
1.22 \\
1.39 \\
1.50 \\
1.68 \\
1.83 \\
2.08 \\
1.96\end{array}$ & $\begin{array}{l}0.07 \\
0.01 \\
0.01 \\
0.03 \\
0.03 \\
0.10 \\
0.16 \\
0.15\end{array}$ & $\begin{array}{l}1.64 \\
1.56 \\
1.59 \\
1.50 \\
1.49 \\
1.53 \\
1.80\end{array}$ & $\begin{array}{l}0.61 \\
0.64 \\
0.61 \\
0.65 \\
0.64 \\
0.57 \\
0.44\end{array}$ \\
\hline \multicolumn{11}{|c|}{ Mimimitoceras varicosum (Schindewolf, 1923) } \\
\hline $\begin{array}{l}\text { MB.C. } 3824.2 \\
\text { MB.C.3824.1 }\end{array}$ & $\begin{array}{r}13.89 \\
14.17 \\
8.76 \\
5.68\end{array}$ & $\begin{array}{r}10.19 \\
10.41 \\
6.97 \\
4.59\end{array}$ & $\begin{array}{l}7.24 \\
7.78 \\
4.61 \\
2.94\end{array}$ & $\begin{array}{l}0.57 \\
0.32 \\
0.43 \\
0.38\end{array}$ & $\begin{array}{l}2.98 \\
3.13 \\
1.69 \\
1.20\end{array}$ & $\begin{array}{l}0.73 \\
0.73 \\
0.80 \\
0.81\end{array}$ & $\begin{array}{l}1.41 \\
1.34 \\
1.51 \\
1.57\end{array}$ & $\begin{array}{l}0.04 \\
0.02 \\
0.05 \\
0.07\end{array}$ & $\begin{array}{l}1.62 \\
1.65 \\
1.53 \\
1.61\end{array}$ & $\begin{array}{l}0.59 \\
0.60 \\
0.63 \\
0.59\end{array}$ \\
\hline \multicolumn{11}{|c|}{ Paragattendorfia aboussalamae n. sp. } \\
\hline $\begin{array}{l}\text { MB.C.3825.1 } \\
\text { MB.C.3825.5 } \\
\text { MB.C.3825.4 }\end{array}$ & $\begin{array}{r}13.71 \\
7.41 \\
10.15 \\
7.67\end{array}$ & $\begin{array}{r}12.14 \\
7.11 \\
9.79 \\
7.36\end{array}$ & $\begin{array}{l}5.37 \\
3.54 \\
3.76 \\
2.96\end{array}$ & $\begin{array}{l}3.67 \\
\\
2.57 \\
1.9\end{array}$ & $\begin{array}{l}2.76 \\
1.82\end{array}$ & $\begin{array}{l}0.89 \\
0.96 \\
0.96 \\
0.96\end{array}$ & $\begin{array}{l}2.26 \\
2.01 \\
2.60 \\
2.49\end{array}$ & $\begin{array}{l}0.27 \\
0.25 \\
0.25\end{array}$ & $\begin{array}{l}1.57 \\
1.48\end{array}$ & 0.49 \\
\hline \multicolumn{11}{|c|}{ Acutimitoceras hollardi $\mathrm{n}$. sp. } \\
\hline $\begin{array}{l}\text { MB.C. } 3827.1 \\
\text { MB.C.3817 }\end{array}$ & $\begin{array}{l}12.7 \\
9.72\end{array}$ & $\begin{array}{l}6.72 \\
5.82\end{array}$ & $\begin{array}{l}6.75 \\
5.52\end{array}$ & $\begin{array}{l}0.8 \\
0.97\end{array}$ & & $\begin{array}{l}0.53 \\
0.60\end{array}$ & $\begin{array}{l}1.00 \\
1.05\end{array}$ & $\begin{array}{l}0.06 \\
0.10\end{array}$ & & \\
\hline
\end{tabular}




\begin{tabular}{|c|c|c|c|c|c|c|c|c|c|c|}
\hline & $\mathrm{dm}$ & ww & wh & uw & $\mathrm{ah}$ & ww/dm & ww/wh & $\mathrm{uw} / \mathrm{dm}$ & WER & IZW \\
\hline \multirow[t]{4}{*}{ MB.C.3827.2 } & 11.15 & 5.94 & 5.96 & 0.7 & 2.63 & 0.53 & 1.00 & 0.06 & 1.71 & 0.56 \\
\hline & 6.52 & 4.34 & 3.34 & 0.82 & 1.48 & 0.67 & 1.30 & 0.13 & 1.67 & 0.56 \\
\hline & 3.86 & 2.90 & 1.77 & 0.79 & 0.86 & 0.75 & 1.64 & 0.20 & 1.66 & 0.51 \\
\hline & 2.34 & 1.83 & 0.99 & 0.63 & 0.55 & 0.78 & 1.85 & 0.27 & 1.71 & 0.44 \\
\hline
\end{tabular}

Acutimitoceras intermedium (Schindewolf, 1923)

\begin{tabular}{|c|c|c|c|c|c|c|c|c|c|c|}
\hline MB.C.3813.3 & 50.02 & 31.06 & 29.94 & 1.92 & & 0.62 & 1.04 & 0.04 & & \\
\hline МВ.С.3813.1 & 46.22 & 30.48 & 26.33 & & 0.66 & 1.16 & & & & \\
\hline МВ.C.3813.2 & 38.83 & 24.30 & 21.67 & & 0.63 & 1.12 & & & & \\
\hline MB.C.3807.1 & 29.55 & 19.3 & 16.76 & 1.33 & & 0.65 & 1.15 & 0.05 & & \\
\hline \multirow[t]{3}{*}{ MB.C.3807.3 } & 20.32 & 13.69 & 11.81 & 0.36 & 5.96 & 0.67 & 1.16 & 0.02 & 2.00 & 0.50 \\
\hline & 10.25 & 7.19 & 5.54 & 0.86 & 2.73 & 0.70 & 1.30 & 0.08 & 1.86 & 0.51 \\
\hline & 5.49 & 4.43 & 2.82 & 0.90 & 1.35 & 0.81 & 1.57 & 1.76 & 0.52 & \\
\hline
\end{tabular}

Acutimitoceras subbilobatum (Münster, 1839)

\begin{tabular}{|c|c|c|c|c|c|c|c|c|c|c|}
\hline MB.C.3809.1 & 27.33 & 15.37 & 15.24 & 0.81 & & 0.56 & 1.01 & 0.03 & & \\
\hline MB.C.3809.2 & 21.04 & 12.53 & 10.99 & 0.95 & & 0.60 & 1.14 & 0.05 & & \\
\hline \multirow[t]{4}{*}{ MB.C.3809.3 } & 17.30 & 8.17 & 9.52 & 1.09 & 4.97 & 0.47 & 0.86 & 0.06 & 1.97 & 0.48 \\
\hline & 9.03 & 4.95 & 4.55 & & & 0.55 & 1.09 & & & \\
\hline & 6.35 & 3.78 & 2.85 & 1.42 & 1.58 & 0.60 & 1.33 & 0.22 & 1.77 & 0.45 \\
\hline & 3.59 & 2.24 & 1.46 & 1.08 & 0.92 & 0.62 & 1.54 & 0.30 & 1.81 & 0.37 \\
\hline \multirow[t]{5}{*}{ MB.C.3809.5 } & 15.99 & 8.88 & 8.76 & 0.87 & 3.67 & 0.56 & 1.01 & 0.05 & 1.68 & 0.58 \\
\hline & 9.49 & 5.64 & 4.72 & 1.47 & 2.31 & 0.59 & 1.19 & 0.15 & 1.75 & 0.51 \\
\hline & 5.65 & 3.31 & 2.35 & 1.61 & 1.39 & 0.59 & 1.41 & 0.28 & 1.76 & 0.41 \\
\hline & 3.19 & 1.81 & 1.19 & 1.14 & 0.82 & 0.57 & 1.52 & 0.36 & 1.81 & 0.31 \\
\hline & 1.76 & 1.10 & 0.67 & 0.53 & 0.43 & 0.63 & 1.64 & 0.30 & 1.75 & 0.36 \\
\hline \multirow[t]{3}{*}{ MB.C.3809.4 } & 8.35 & 5.19 & 4.22 & 1.28 & 1.99 & 0.62 & 1.23 & 0.15 & 1.73 & 0.53 \\
\hline & 4.78 & 2.93 & 2.08 & 1.24 & 1.19 & 0.61 & 1.41 & 0.26 & 1.77 & 0.43 \\
\hline & 2.67 & 1.54 & 1.06 & 0.82 & 0.69 & 0.58 & 1.45 & 0.31 & 1.81 & 0.35 \\
\hline \multicolumn{11}{|c|}{ Acutimitoceras posterum n. $\mathrm{sp}$. } \\
\hline MB.C.3828.1 & 15.81 & 10.49 & 7.90 & 0.87 & 4.30 & 0.66 & 1.33 & 0.06 & 1.89 & 0.46 \\
\hline \multirow[t]{3}{*}{ MB.C.3828.2 } & 12.80 & 8.61 & 7.25 & 0.16 & 3.27 & 0.67 & 1.19 & 0.01 & 1.80 & 0.55 \\
\hline & 7.12 & 4.59 & 3.68 & 0.68 & 1.71 & 0.64 & 1.25 & 0.10 & 1.73 & 0.53 \\
\hline & 4.07 & 2.50 & 1.69 & 1.22 & 1.06 & 0.61 & 1.48 & 0.30 & 1.82 & 0.37 \\
\hline \multirow[t]{5}{*}{ MB.C.3828.4 } & 12.88 & 8.11 & 7.30 & 0.35 & 3.33 & 0.63 & 1.11 & 0.03 & 1.82 & 0.54 \\
\hline & 6.95 & 4.43 & 3.58 & 1.16 & 1.87 & 0.64 & 1.24 & 0.17 & 1.87 & 0.48 \\
\hline & 3.81 & 2.43 & 1.50 & 1.39 & 0.95 & 0.64 & 1.62 & 0.36 & 1.77 & 0.37 \\
\hline & 2.20 & 1.41 & 0.71 & 0.94 & 0.48 & 0.64 & 1.99 & 0.43 & 1.64 & 0.32 \\
\hline & 1.30 & 0.98 & 0.48 & 0.39 & 0.33 & 0.75 & 2.04 & 0.30 & 1.80 & 0.31 \\
\hline
\end{tabular}

Acutimitoceras mfisense n. sp.

\begin{tabular}{|c|c|c|c|c|c|c|c|c|c|c|}
\hline \\
\hline MB.C.3811.1 & 17.01 & 8.32 & 10.44 & & & 0.49 & 0.80 & & & \\
\hline \multirow{3}{*}{ MB.C.3811.2 } & 18.41 & 8.77 & 10.96 & 0.42 & 5.18 & 0.48 & 0.80 & 0.02 & 1.94 & 0.53 \\
\hline & 9.74 & 5.18 & 5.02 & 1.34 & 2.48 & 0.53 & 1.03 & 0.14 & 1.80 & 0.51 \\
\hline & 5.41 & 2.80 & 2.15 & 1.76 & 1.28 & 0.52 & 1.30 & 0.33 & 1.71 & 0.41 \\
\hline \multirow[t]{5}{*}{ MB.C.3829.3 } & 10.92 & 4.48 & 6.16 & 0.61 & 3.21 & 0.41 & 0.73 & 0.06 & 2.01 & 0.48 \\
\hline & 5.63 & 2.65 & 2.64 & 1.32 & 1.42 & 0.47 & 1.00 & 0.23 & 1.79 & 0.46 \\
\hline & 3.23 & 1.53 & 0.99 & 1.53 & 0.66 & 0.47 & 1.55 & 0.47 & 1.58 & 0.33 \\
\hline & 2.06 & 1.05 & 0.63 & 0.94 & 0.42 & 0.51 & 1.67 & 0.46 & 1.58 & 0.33 \\
\hline & 1.27 & 0.78 & 0.43 & 0.36 & 0.29 & 0.61 & 1.81 & 0.28 & 1.68 & 0.33 \\
\hline \multirow[t]{3}{*}{ MB.C.3811.6 } & 17.74 & 7.95 & 10.38 & 0.52 & 5.52 & 0.45 & 0.77 & 0.03 & 2.11 & 0.47 \\
\hline & 8.79 & 4.57 & 4.71 & 0.97 & 2.47 & 0.52 & 0.97 & 0.11 & 1.93 & 0.48 \\
\hline & 4.64 & 2.32 & 1.77 & 1.79 & 1.04 & 0.50 & 1.31 & 0.39 & 1.66 & 0.41 \\
\hline \multicolumn{11}{|c|}{ Acutimitoceras occidentale n. sp. } \\
\hline MB.C.3810.1 & 25.89 & 14.47 & 14.31 & 0.72 & 8.69 & 0.56 & 1.01 & 0.03 & & 0.39 \\
\hline MB.C.3810.3 & 18.43 & 9.23 & 10.07 & 0.77 & & 0.50 & 0.92 & 0.04 & & \\
\hline МВ.С.3810.7 & 12.69 & 8.14 & 7.04 & 0.49 & 3.55 & 0.64 & 1.16 & 0.04 & 1.93 & 0.50 \\
\hline MB.C.3826.1 & 9.38 & 5.33 & 4.33 & 1.34 & & 0.57 & 1.23 & 0.14 & & \\
\hline MB.C.3826.2 & 6.81 & 4.54 & 3.35 & 1.10 & 1.54 & 0.67 & 1.36 & 0.16 & 1.67 & 0.54 \\
\hline МВ.С.3826.3 & 3.81 & 2.93 & 1.43 & 1.17 & 0.97 & 0.77 & 2.05 & 0.31 & 1.80 & 0.32 \\
\hline \multirow[t]{3}{*}{ MB.C.3810.6 } & 22.42 & 11.86 & 12.56 & 0.41 & 6.24 & 0.53 & 0.94 & 0.02 & 1.92 & 0.50 \\
\hline & 11.59 & 7.12 & 6.51 & 0.50 & 3.15 & 0.61 & 1.09 & 0.04 & 1.89 & 0.52 \\
\hline & 6.20 & 4.22 & 3.23 & 0.71 & 1.58 & 0.68 & 1.31 & 0.11 & 1.81 & 0.51 \\
\hline \multirow[t]{4}{*}{ MB.C.3826.4 } & 7.73 & 4.93 & 3.95 & 1.09 & 2.21 & 0.64 & 1.25 & 0.14 & 1.96 & 0.44 \\
\hline & 4.14 & 3.08 & 1.91 & 0.93 & 0.98 & 0.74 & 1.61 & 0.22 & 1.72 & 0.49 \\
\hline & 2.43 & 1.82 & 0.98 & 0.76 & 0.59 & 0.75 & 1.86 & 0.31 & 1.75 & 0.39 \\
\hline & 1.46 & 1.20 & 0.48 & 0.51 & 0.33 & 0.82 & 2.48 & 0.35 & 1.67 & 0.32 \\
\hline
\end{tabular}




\begin{tabular}{|c|c|c|c|c|c|c|c|c|c|c|}
\hline & $\mathrm{dm}$ & ww & wh & uw & $\mathrm{ah}$ & $\mathrm{ww} / \mathrm{dm}$ & ww/wh & $\mathrm{uw} / \mathrm{dm}$ & WER & IZW \\
\hline \multicolumn{11}{|c|}{ Acutimitoceras sp. 2} \\
\hline MB.C.3808.1 & 15.27 & 12.74 & 7.91 & 0.98 & & 0.83 & 1.61 & 0.06 & & \\
\hline MB.C.3808.4 & 14.29 & 10.80 & 8.52 & & & 0.76 & 1.27 & & & \\
\hline \multirow[t]{4}{*}{ MB.C.3808.3 } & 12.78 & 8.67 & 6.91 & 1.02 & 3.16 & 0.68 & 1.25 & 0.08 & 1.77 & 0.54 \\
\hline & 7.40 & 4.78 & 3.50 & 1.53 & 1.64 & 0.65 & 1.37 & 0.21 & 1.65 & 0.53 \\
\hline & 4.50 & 2.68 & 1.71 & 1.58 & 0.98 & 0.60 & 1.57 & 0.35 & 1.63 & 0.43 \\
\hline & 2.79 & 1.53 & 0.96 & 1.07 & 0.61 & 0.55 & 1.59 & 0.38 & 1.64 & 0.37 \\
\hline \multirow[t]{4}{*}{ MB.C.3808.2 } & 12.69 & 9.46 & 7.04 & 0.62 & 3.28 & 0.75 & 1.34 & 0.05 & 1.82 & 0.53 \\
\hline & 7.19 & 5.16 & 3.48 & 1.18 & 1.55 & 0.72 & 1.48 & 0.16 & 1.62 & 0.55 \\
\hline & 4.48 & 2.97 & 1.93 & 1.09 & 0.97 & 0.66 & 1.54 & 0.24 & 1.63 & 0.50 \\
\hline & 2.77 & 1.58 & 1.05 & 0.93 & 0.61 & 0.57 & 1.50 & 0.34 & 1.65 & 0.42 \\
\hline \multicolumn{11}{|c|}{ Nicimitoceras trochiforme (Vöhringer, 1960) } \\
\hline МB.C.3830.2 & 17.71 & 8.92 & 9.62 & 1.24 & 5.02 & 0.50 & 0.93 & 0.07 & 1.95 & 0.48 \\
\hline MB.C.3830.3 & 9.67 & 5.44 & 5.27 & 0.9 & 2.68 & 0.56 & 1.03 & 0.09 & 1.91 & 0.49 \\
\hline \multirow[t]{4}{*}{ MB.C.3830.4 } & 7.59 & 4.58 & 4.14 & 0.49 & 2.16 & 0.60 & 1.11 & 0.07 & 1.95 & 0.48 \\
\hline & 3.98 & 2.87 & 1.91 & 0.69 & 0.97 & 0.72 & 1.50 & 0.17 & 1.74 & 0.50 \\
\hline & 2.29 & 1.75 & 0.96 & 0.59 & 0.53 & 0.78 & 1.86 & 0.26 & 1.69 & 0.45 \\
\hline & 1.38 & 1.26 & 0.65 & 0.21 & 0.36 & 0.93 & 1.93 & 0.15 & 1.83 & 0.45 \\
\hline
\end{tabular}

Imitoceras oxydentale $\mathrm{n} . \mathrm{sp}$.

\begin{tabular}{|c|c|c|c|c|c|c|c|c|c|c|}
\hline MB.C.3831.1 & 18.0 & 8.21 & 11.09 & & & 0.46 & 0.74 & & & \\
\hline MB.C.3831.4 & 14.4 & 7.21 & 8.55 & 0.64 & 5.28 & 0.50 & 0.84 & 0.04 & & 0.38 \\
\hline MB.C.3831.6 & 10.9 & 5.58 & 6.31 & & & 0.51 & 0.88 & & & \\
\hline \multirow[t]{3}{*}{ MB.C.3831.3 } & 10.82 & 4.93 & 6.18 & 0.56 & 3.37 & 0.46 & 0.80 & 0.05 & 2.11 & \\
\hline & 5.28 & 2.60 & 2.55 & 0.97 & 1.42 & 0.49 & 1.02 & 0.18 & 1.87 & \\
\hline & 2.95 & 1.42 & 0.92 & 1.21 & 0.59 & 0.48 & 1.54 & 0.41 & 1.57 & \\
\hline \multirow[t]{5}{*}{ MB.C.3831.7 } & 16.90 & 6.95 & 9.71 & 0.34 & 5.27 & 0.41 & 0.72 & 0.02 & 2.11 & \\
\hline & 8.06 & 3.79 & 4.55 & 0.66 & 2.28 & 0.47 & 0.83 & 0.08 & 1.94 & \\
\hline & 4.36 & 2.15 & 2.01 & 1.12 & 1.04 & 0.49 & 1.07 & 0.26 & 1.72 & \\
\hline & 2.54 & 1.23 & 0.85 & 1.13 & 0.58 & 0.48 & 1.45 & 0.44 & 1.68 & \\
\hline & 1.53 & 0.82 & 0.51 & 0.58 & 0.36 & 0.54 & 1.61 & 0.38 & 1.71 & \\
\hline
\end{tabular}

Gattendorfia crassa Schmidt, 1924

\begin{tabular}{|c|c|c|c|c|c|c|c|c|c|c|}
\hline MB.C.3832.3 & 19.65 & 12.53 & 8.79 & 5.16 & 6.19 & 0.64 & 1.43 & 0.26 & & 0.30 \\
\hline MB.C.3832.2 & 17.88 & 11.63 & 8.16 & 4.85 & 6.09 & 0.65 & 1.43 & 0.27 & & 0.25 \\
\hline MB.C.3832.1 & 10.28 & 7.36 & 4.40 & 3.31 & 3.02 & 0.72 & 1.67 & 0.32 & & 0.31 \\
\hline \multirow[t]{4}{*}{ MB.C.3832.8 } & 11.31 & 7.32 & 4.74 & 4.02 & 2.85 & 0.65 & 1.54 & 0.35 & 1.79 & 0.40 \\
\hline & 6.72 & 3.77 & 1.66 & 3.80 & 1.28 & 0.56 & 2.28 & 0.57 & 1.53 & \\
\hline & 4.42 & 2.15 & 0.89 & 2.80 & 0.71 & 0.49 & 2.41 & 0.63 & 1.42 & \\
\hline & 3.06 & 1.44 & 0.66 & 1.79 & 0.51 & 0.47 & 2.20 & 0.58 & 1.44 & \\
\hline \multirow[t]{2}{*}{ MB.C.3832.5 } & 10.62 & 7.63 & 3.85 & 4.11 & 2.45 & 0.72 & 1.98 & 0.39 & 1.69 & \\
\hline & 6.33 & 3.63 & 1.81 & 3.13 & 1.29 & 0.57 & 2.00 & 0.49 & 1.58 & 0.29 \\
\hline \multirow[t]{2}{*}{ MB.C.3832.4 } & 9.01 & 5.86 & 3.08 & 3.93 & 2.04 & 0.65 & 1.90 & 0.44 & 1.67 & 0.3 \\
\hline & 5.50 & 3.14 & 1.38 & 3.06 & 1.04 & 0.57 & 2.28 & 0.56 & 1.52 & .2 .2 \\
\hline
\end{tabular}

Gattendorfia jacquelinae Ebbighausen. Bockwinkel. Korn \& Weyer, 2004

$\begin{array}{lrrrrrrrrrr}\text { MB.C.3833.1 } & 16.26 & 12.17 & 8.49 & & & 0.75 & & 0.52 & \\ \text { MB.C.3833.2 } & 13.90 & 9.47 & 4.03 & 7.25 & 3.22 & 0.68 & 2.35 & 0.52 & 1.69 & 0.20 \\ \text { MB.C.3833.8 } & 13.50 & 10.83 & 3.89 & 6.56 & & 0.80 & 2.78 & 0.49 & & \\ \text { MB.C.3833.9 } & 13.21 & 9.91 & 4.11 & 6.55 & 2.76 & 0.75 & 2.41 & 0.50 & 1.60 & 0.33 \\ \text { MB.C.3833.7 } & 12.45 & 7.18 & 3.02 & 7.05 & & 0.58 & 2.38 & 0.57 & \\ \text { MB.C.3833.3 } & 12.25 & 8.46 & 3.58 & 5.88 & & 0.69 & 2.36 & 0.48 & \\ \text { MB.C.3833.4 } & 12.62 & 8.90 & 3.67 & 5.92 & 2.25 & 0.71 & 2.43 & 0.47 & 1.48 & 0.39 \\ & 8.41 & 5.14 & 2.28 & 4.32 & 1.72 & 0.61 & 2.26 & 0.51 & 1.58 & 0.25 \\ & 5.16 & 3.10 & 1.33 & 2.85 & 0.99 & 0.60 & 2.32 & 0.55 & 1.53 & 0.26 \\ & 3.42 & 1.72 & 0.92 & 1.76 & 0.77 & 0.50 & 1.88 & 0.51 & 1.66 & 0.16 \\ \text { MB.C.3833.5 } & 2.08 & 1.21 & 0.60 & 0.93 & 0.46 & 0.58 & 2.02 & 0.45 & 1.64 & 0.24 \\ & 12.92 & 9.28 & 4.04 & 5.97 & 2.57 & 0.72 & 2.30 & 0.46 & 1.56 & 0.36 \\ & 8.18 & 5.26 & 2.34 & 4.12 & 1.60 & 0.64 & 2.24 & 0.50 & 1.54 & 0.32 \\ & 5.31 & 2.85 & 1.37 & 2.93 & 1.03 & 0.54 & 2.08 & 0.55 & 1.54 & 0.24 \\ \text { MB.C.3833.6 } & 3.50 & 1.76 & 0.85 & 1.91 & 0.62 & 0.50 & 2.06 & 0.55 & 1.47 & 0.28 \\ & 2.36 & 1.20 & 0.59 & 1.23 & 0.43 & 0.51 & 2.02 & 0.52 & 1.50 & 0.27 \\ & 13.34 & 8.95 & 4.61 & 5.81 & 0.67 & & 1.94 & 0.44 & & 0.29 \\ & 7.94 & 6.12 & 2.27 & 4.23 & 1.58 & 0.77 & 2.69 & 0.53 & 1.56 & 0.31 \\ & 5.18 & 2.94 & 1.26 & 2.89 & 1.00 & 0.57 & 2.34 & 0.56 & 1.54 & 0.20 \\ & 3.38 & 1.58 & 0.74 & 2.00 & 0.56 & 0.47 & 2.14 & 0.59 & 1.43 & 0.25\end{array}$




\begin{tabular}{|c|c|c|c|c|c|c|c|c|c|c|}
\hline & $\mathrm{dm}$ & ww & wh & uw & $\mathrm{ah}$ & ww/dm & ww/wh & $\mathrm{uw} / \mathrm{dm}$ & WER & IZW \\
\hline \multicolumn{11}{|c|}{ Kazakhstania evoluta (Vöhringer, 1960) } \\
\hline MB.C.3820.1 & 9.26 & 3.87 & 1.73 & 5.86 & 1.66 & 0.42 & 2.24 & 0.63 & 1.48 & 0.04 \\
\hline MB.C.3820.2 & 7.21 & 3.01 & 1.52 & 4.47 & 1.40 & 0.42 & 1.98 & 0.62 & 1.54 & 0.08 \\
\hline \multirow[t]{5}{*}{ MB.C.3820.4 } & 9.00 & 3.50 & 1.88 & 5.63 & 1.66 & 0.39 & 1.86 & 0.63 & 1.50 & 0.12 \\
\hline & 5.91 & 2.08 & 1.24 & 3.69 & 1.13 & 0.35 & 1.67 & 0.63 & 1.53 & 0.09 \\
\hline & 3.81 & 1.27 & 0.76 & 2.42 & 0.75 & 0.33 & 1.67 & 0.63 & 1.55 & 0.02 \\
\hline & 2.47 & 1.00 & 0.49 & 1.54 & 0.46 & 0.41 & 2.03 & 0.62 & 1.51 & 0.07 \\
\hline & 1.59 & 0.83 & 0.39 & & 0.52 & 2.13 & & & & \\
\hline \multicolumn{11}{|c|}{ Kazakhstania colubrella ? (Morton, 1836) } \\
\hline \multirow[t]{2}{*}{ MB.C.3834 } & 12.17 & 4.63 & 3.92 & 5.16 & 2.48 & 0.38 & 1.18 & 0.42 & 1.58 & 0.37 \\
\hline & 7.29 & & 1.68 & 3.96 & & & & 0.54 & & \\
\hline \multicolumn{11}{|c|}{ Kazakhstania nitida n. sp. } \\
\hline MB.C.3835.1 & 15.73 & 7.16 & 3.91 & 8.75 & & & & 0.46 & 1.83 & 0.56 \\
\hline MB.C.3836.1 & 14.36 & 11.66 & 4.89 & 5.91 & 3.09 & 0.81 & 2.38 & 0.41 & 1.62 & 0.37 \\
\hline \multirow[t]{6}{*}{ MB.C.3835.4 } & 11.77 & 6.08 & 2.83 & 6.75 & 2.06 & 0.52 & 2.15 & 0.57 & 1.47 & 0.27 \\
\hline & 7.95 & 2.97 & 1.76 & 4.96 & 1.36 & 0.37 & 1.69 & 0.62 & 1.45 & 0.23 \\
\hline & 5.56 & 1.87 & 1.11 & 3.48 & 0.93 & 0.34 & 1.68 & 0.63 & 1.44 & 0.17 \\
\hline & 3.88 & 1.30 & 0.75 & 2.44 & 0.64 & 0.34 & 1.74 & 0.63 & 1.43 & 0.15 \\
\hline & 2.69 & 1.02 & 0.57 & 1.59 & 0.44 & 0.38 & 1.77 & 0.59 & 1.43 & 0.23 \\
\hline & 1.85 & 0.84 & 0.49 & 0.90 & 0.38 & 0.45 & 1.72 & 0.48 & 1.58 & 0.23 \\
\hline \multicolumn{11}{|c|}{ Zadelsdorfia debouaaensis n. sp. } \\
\hline MB.C.3836.2 & 14.8 & 12.56 & 4.76 & 6.99 & 3.25 & 0.85 & 2.64 & 0.47 & 1.64 & 0.32 \\
\hline
\end{tabular}

MB.C.3836.2 14.8

$\begin{array}{llllllllll}\text { MB.C.3836.1 } & 14.36 & 11.66 & 4.89 & 5.91 & 3.09 & 0.81 & 2.38 & 0.41 & 1.62\end{array}$

Weyerella minor $\mathrm{n} . \mathrm{sp}$.

$\begin{array}{lllll}\text { MB.C.3838.1 } & 9.85 & 4.50 & 4.27 & 2.37 \\ \text { MB.C.3838.2 } & 6.99 & 3.68 & 2.65 & 2.17 \\ \text { MB.C.3838.3 } & 8.55 & 4.12 & 3.67 & 2.29 \\ & 4.24 & 2.49 & 1.75 & 1.32 \\ & 2.19 & 1.42 & 0.76 & 0.77 \\ \text { MB.C.3821.1 } & 1.20 & 0.98 & 0.48 & 0.40 \\ & 6.00 & 3.12 & 2.25 & 2.21 \\ & 3.17 & 1.98 & 1.10 & 1.29 \\ & 1.73 & 1.26 & 0.62 & 0.64\end{array}$

$\begin{array}{llllll} & 0.46 & 1.05 & 0.24 & & \\ 2.48 & 0.53 & 1.39 & 0.31 & & \\ 1.20 & 0.48 & 1.12 & 0.27 & 1.98 & 0.32 \\ 0.55 & 0.65 & 1.42 & 0.31 & 1.95 & 0.31 \\ 0.31 & 0.82 & 1.86 & 0.35 & 1.79 & 0.27 \\ 1.64 & 0.52 & 1.03 & 0.33 & 1.81 & 0.36 \\ 0.85 & 0.63 & 1.80 & 0.41 & 1.87 & 0.27 \\ 0.45 & 0.73 & 2.04 & 0.37 & 1.83 & 0.27\end{array}$

Weyerella protecta $\mathrm{n}$. sp.

$\begin{array}{lrl}\text { MB.C.3837.1 } & 20.10 & 7.53 \\ \text { MB.C.3837.2 } & 18.21 & 7.58 \\ \text { MB.C.3837.3 } & 17.00 & 7.51 \\ & 10.24 & 5.22 \\ & 5.77 & 2.98 \\ \text { MB.C.3837.4 } & 3.24 & 1.50 \\ & 19.50 & 8.00 \\ \text { MB.C.3837.5 } & 12.13 & 5.25 \\ & 7.14 & 3.54 \\ & 11.32 & 5.44 \\ & 6.26 & 3.35 \\ & 3.35 & 1.83 \\ & 1.89 & 1.16\end{array}$

$\begin{array}{ll}7.85 & 7.37 \\ 6.42 & 7.57\end{array}$

$6.58 \quad 5.96$

$3.29 \quad 4.27$

$1.88 \quad 2.51$

$0.91 \quad 2.33$

$6.94 \quad 7.35$

$3.61 \quad 5.62$

$2.31 \quad 3.02$

$\begin{array}{ll}3.96 & 4.26 \\ 2.32 & 2.35\end{array}$

$\begin{array}{ll}1.10 & 1.51 \\ 0.66 & 0.67\end{array}$

(1)

0.97

2.29

Eocanites simplex n. sp.

$\begin{array}{ll}\text { MB.C.3841.1 } & 9.77 \\ \text { Eocanites rtbeckeri n. sp. }\end{array}$

$9.77 \quad 4.12$

$2.72 \quad 4.95$

3.80

0.37

0.96

0.42

2.47

0.44

0.51

1.18

1.14

0.52

1.59

1.59

0.41

1.15

0.43

0.49

0.48

0.54

0.55

0.61

1.45

1.53

1.37

1.44

1.66

1.74

0.37

0.42

0.35

0.42

0.44

0.46

0.38

0.46

0.42

0.38

0.38

0.45

0.35

1.66

1.74

1.77

1.65

1.53

1.67

1.77

1.72

1.85

1.83
1.80

0.42

0.25

0.24

0.46

0.24

0.23

0.32

0.29

0.21

MB.C.3839.1 12.16

$\begin{array}{rr}12.16 & 3.96 \\ 16.28 & 4.95 \\ 8.76 & 3.16 \\ 4.64 & 2.06 \\ 2.53 & 1.15\end{array}$

$3.62 \quad 5.94$

$\begin{array}{ll}4.53 & 8.23 \\ 2.42 & 4.26\end{array}$

$2.42 \quad 4.26$

1.42
0.66

$2.25-2.25$

0.42

1.51

0.51

1.81

0.08

Eocanites dkorni n. sp.

$\begin{array}{lrrrr}\text { MB.C.3840.1 } & 16.56 & 3.13 & 3.91 & 9.73 \\ \text { MB.C.3840.2 } & & 4.74 & 6.02 & 5.72 \\ \text { MB.C.3840.3 } & & 11.31 & 13.81 & 13.7 \\ \text { MB.C.3822 } & 8.51 & 2.67 & 2.25 & 4.57\end{array}$

0.33
0.30
0.36
0.44

1.09

1.09
1.31

0.49

0.51

0.49

0.48

1.96

1.86
1.81

1.87

0.04

1.45

0.45

1.74

0.07

0.12

MB.C.3822

2.25

4.57

3.82

$\begin{array}{ll}0.19 & 0.80 \\ & 0.79 \\ & 0.82 \\ 0.31 & 1.19\end{array}$

0.59

1.69

0.02

0.05 